\title{
Representações de comunidade para o trabalho em saúde: demandas e necessidades médico-sociais no cotidiano das práticas do Programa de Saúde da Família.
}

\author{
Dissertação apresentada à Faculdade de \\ Medicina da Universidade de São Paulo para \\ obtenção do título de Mestre em Ciências. \\ Área de Concentração: Medicina Preventiva \\ Orientadora: Profa. Dra. Márcia Thereza Couto Falcão
}

São Paulo 


\section{Dados Internacionais de Catalogação na Publicação (CIP)}

Preparada pela Biblioteca da

Faculdade de Medicina da Universidade de São Paulo

(C)reprodução autorizada pelo autor

Palma, Ariane Machado

Representações de comunidade para o trabalho em saúde : demandas e necessidades médico-sociais no cotidiano das práticas do Programa de Saúde da Familia / Ariane Machado Palma. -- São Paulo, 2009.

Dissertação(mestrado)--Faculdade de Medicina da Universidade de São Paulo.

Departamento de Medicina Preventiva.

Área de concentração: Medicina Preventiva.

Orientadora: Márcia Thereza Couto Falcão.

Descritores: 1.Atenção primária à saúde 2. Saúde comunitária 3.Programa saúde da família 4.Necessidades e demandas de serviços de saúde 5.Pessoal de saúde 6.Assistência integral à saúde 


\section{FOLHA DE APROVAÇÃO}

Ariane Machado Palma

Representações de comunidade para o trabalho em saúde: demandas e necessidades médicosociais no cotidiano das práticas do Programa de Saúde da Família.

Dissertação apresentada à Faculdade de Medicina da Universidade de São Paulo para obtenção do título de Mestre em Ciências. Área de Concentração: Medicina Preventiva

Aprovado em:

Banca Examinadora

Prof. Dr.:

Instituição: Assinatura:

Prof. Dr.:

Instituição:

Assinatura:

Prof. Dr.:

Instituição:

Assinatura:

Prof. Dr.:

Instituição: Assinatura: 
Àqueles usuários dos serviços de saúde que nos encontros cotidianos em territórios adversos ensinam o respeito às suas subjetividades.

Àqueles trabalhadores de saúde que permanecem na luta pela cidadania, saúde e reconhecimento de demandas e necessidades dos que sofrem e estão às margens da sociedade.

Dedico 


\section{AGRADECIMENTOS}

Aos usuários dos serviços de saúde, pessoas excluídas socialmente e comunidades que pude conviver na trajetória, pelo grande aprendizado e compartilhar de histórias de vida.

Aos profissionais de saúde da USF estudada, pela disponibilidade e desejo em ajudar a concretizar esta dissertação.

À Profa. Dra. Márcia Thereza Couto, que prontamente aceitou ser orientadora continuando a parceria de trabalho iniciada na especialização. Pela amizade, orientações precisas, e, principalmente, pelo respeito ao meu tempo em meio às circunstâncias da vida.

Aos professores e funcionários do Departamento de Medicina Preventiva - FMUSP, pela disposição em colaborar. Em especial, à Lílian Santos, pela amizade e 'ajudas burocráticas'.

À Profa. Dra. Ana Lúcia Machado e à Profa. Dra. Luciana de Almeida Colvero da EEUSP, pelo acolhimento e aproximação das discussões sob a perspectiva da subjetividade.

À Débora Ribeiro Freire e à Heloísa Hanada, por serem auxiliares de pesquisa relatando o grupo focal.

À Thalita Kelen Leal do Prado, pela ajuda nas árduas transcrições das entrevistas.

À prima e filósofa Maria Cristina Mendes Machado, pela ajuda até altas horas na elaboração dos ensaios filosóficos a quatro mãos.

À Banca de Qualificação composta por: Profa. Dra. Roseli Esquerdo Lopes, Profa. Dra. Eunice Nakamura e Profa. Dra. Lília Blima Schraiber, pelas valiosas contribuições.

Aos integrantes da Equipe de Saúde Mental do PSF, que tive o privilégio de trabalhar em meio ao 'olho do furacão', pelas reflexões, risadas e acolhimentos. Em especial, à Gianne Carvalho de Sousa, pela parceria diária regada a um bom repertório musical. 
Aos profissionais das equipes nucleares e ampliadas da UBS Reunidas I, pelas perguntas curiosas sobre o tema de pesquisa. Em especial, aos integrantes das ESF que trabalhei diretamente por me ajudarem na construção de muitas reflexões aqui presentes.

À Márcia Regina Kretzer, Carolina Magnani, Wania Regina Veiga Martinez e Ramiro Fernandes Pedro, pelas liberações institucionais para a continuidade desta pesquisa.

À Profa. Dra. Roseli Esquerdo Lopes, mestra e amiga, por ensinar a Terapia Ocupacional em seu 'aspecto macro e micro' e fundamentar meus primeiros passos enquanto pesquisadora com muita dedicação possibilitando a busca de novos caminhos, meu terno reconhecimento.

À Ligia Pupo, pelo suporte terapêutico e construção do pensamento de pesquisadora.

Aos amigos e parceiros: Juliana A. Ometto, Marília B. Othero, Patrícia L. de Oliveira Borba, Ângela Yuri Koketsu, Ana Paula S. Malfitano, Adriana Leão, Paula Giovana Furlan, Wagner Oda, Rosangela G. de Souza e Thamara F. Santos, pelos bons momentos, compartilhar de idéias e discussões sobre ser profissional de saúde e terapeuta ocupacional.

Aos ‘amigos de interfaces’ encontrados nos campos da Saúde Coletiva, Saúde Mental e Educação em Saúde: Débora Barros, Juliana Guisardi Pereira, Renata Bellenzani e Rebeca Barros, pela escuta, sugestões e conversas sobre o trabalho, as pesquisas e a vida.

Aos amigos de retaguarda Liliane, Geane, Rose, Débora, Ricardo, Andréa, Filipe, Sania, André, Angélica, Renata, Lauro, Paulo, Taciana, Marcela, por sempre entenderem meus sumiços e valorizarem minha carreira profissional com respeito e carinho.

Às Famílias Prado, Machado e Rodrigues, pelo apoio, conversas repletas de bom humor e orações fortalecedoras.

E neste momento especial, a minha sincera gratidão:

Aos meus pais Altair Palma e Maria Luiza Tavares Machado Palma, que amam e protegem incondicionalmente, por acompanharem a caminhada, auxiliarem nas idas e vindas, 
enxugarem as lágrimas, correrem contra o tempo e, principalmente, me ensinarem o valor dos estudos.

Ao Junior Leal do Prado, pela paciência nos momentos críticos, ajuda nas madrugadas reflexivas, esforço em tentar construir pontes entre as exatas e as biológicas e humanas, e, principalmente, por não permitir que desistisse dos meus desejos profissionais, embora implicassem em ausências e diálogos monotemáticos. A você, meu carinho e amor.

A Deus, “que chama à existência as cousas que não existem” (Romanos 4:17 - Bíblia Sagrada), por me revestir de perseverança e sabedoria para desenvolver mais uma etapa da carreira profissional e embasar através dos ensinamentos bíblicos o respeito ao Outro e à Vida. 
tentei olhar (...) para todas as cenas. Não mais sob a ótica de que o presente era duro e que o futuro seria muito mais duro. Procurei olhálas como "lugares", onde encontram-se ou relacionam-se territóriossujeitos, em acontecimentos e aconteceres. E, aí, todas essas cenas começaram a expressar outras possibilidades: ali, existiam sujeitos, territorializados e em desterritorializações, encontrando-se nas suas dificuldades, nas suas comensalidades, nas suas possibilidades, nas suas lutas; o que permitia olhar os encontros (MERHY, 2007, p.26).

Cuidar da saúde de alguém é mais que construir um objeto e intervir sobre ele. Para cuidar há que se considerar e construir projetos; há que se sustentar, ao longo do tempo, uma certa relação entre a matéria e o espírito, o corpo e a mente, moldados a partir de uma forma que o sujeito quer opor à dissolução, inerte e amorfa, de sua presença no mundo. Então é forçoso saber qual é o projeto de felicidade que está ali em questão, no ato assistencial, mediato ou imediato. A atitude de cuidar não pode ser apenas uma pequena e subordinada tarefa parcelar das práticas de saúde. A atitude "cuidadora" precisa se expandir mesmo para a totalidade das reflexões e intervenções no campo da saúde (AYRES, 2001, p.71). 


\section{RESUMO}

\section{PALMA, A. M. Representações de comunidade para o trabalho em saúde: demandas e}

necessidades médico-sociais no cotidiano das práticas do Programa de Saúde da Família. 2009. Dissertação (Mestrado) - Faculdade de Medicina, Universidade de São Paulo, São Paulo, 2009.

Trata-se das representações de comunidade para o trabalho em saúde tal como a tomam os profissionais do Programa de Saúde da Família (PSF) tendo por base demandas e necessidades médico-sociais: violência, uso abusivo de álcool e drogas, e sofrimento mental, em um serviço de atenção primária à saúde no município de São Paulo. O percurso metodológico adotado é o da pesquisa qualitativa na modalidade de Estudo de Caso e as técnicas utilizadas foram: entrevista em profundidade semi-estruturada e grupo focal. $\mathrm{O}$ serviço de saúde estudado localiza-se em um território definido por 'bolsão de pobreza' e é composto por duas equipes de saúde da família e três equipes 'ampliadas' de saúde bucal, mental e de reabilitação. Vinte e seis profissionais de saúde participaram do estudo. A análise dos dados empíricos parte de três núcleos temáticos: trajetórias e percepções do cotidiano de práticas do PSF; relação ‘serviço de saúde e comunidade’; e compreensões temáticas das demandas e necessidades médico-sociais da comunidade. Neste sentido, apreendem-se limites e potencialidades do trabalho em saúde e da relação ‘serviço de saúde e comunidade’ frente às demandas e necessidades relacionadas à violência, uso abusivo de álcool e drogas, e sofrimento mental; e discute-se que os profissionais de saúde possuem diferentes percepções acerca de comunidade, o que influencia diretamente o ser profissional diante dela. Compreende-se que profissionais de saúde podem instigar e integrar abordagens intersetoriais para atuarem com demandas e necessidades médico-sociais da comunidade, dependendo assim, se estas forem desveladas e acolhidas nas práticas de cuidado dos serviços de atenção primária à saúde.

Descritores: 1. Atenção Primária à Saúde 2. Saúde Comunitária 3. Programa Saúde da Família 4. Necessidades e Demandas de Serviços de Saúde 5. Pessoal de Saúde 6. Assistência Integral à Saúde 


\begin{abstract}
PALMA, A. M. Representations of the community to the work in health: medical-social demands and necessities in the daily practices of the Family Health Program. 2009. Master's Thesis - School of Medicine, University of Sao Paulo, Sao Paulo, 2009.
\end{abstract}

It is about the representations of the community to the work in health, as well as the family health program professionals take it, having as a base the medical-social necessities: violence, overuse of alcohol and drugs, mental suffering in a primary attention health service in Sao Paulo municipality. The methodology adopted is the qualitative research in the case study modality and the techniques used were: semi-structured deep interview and focal group. The health service studied is placed in a territory defined as 'poverty pool' and it is composed by two family health groups and three 'amplified' buccal, mental health and rehabilitation. Twenty six health professionals participated in this study. The empiric data analysis starts from three thematic nucleuses: trajectory and daily perception of the practices of the FHP; relation 'health service and community'; and thematic comprehension about the medicalsocial demands and necessities of the community. In this way, it is learned the limits and potentialities of the work in health and the relation 'health service and community' before the demands and necessities related to violence, overuse of alcohol and drugs and mental suffering; and it is discussed that health professionals have different perceptions about the community, what influences directly the professional before it. It is understood that health professionals can instigate and integrate intersectorial approaches to deal with medical-social demands and necessities of the community, depending if these are unveiled and included in the practices of care of primary attention services to health.

Descriptors: 1. Primary Health Care 2. Community Health 3. Family Health Program 4. Health Services Needs and Demand 5.Health Personnel 6. Integral Health Assistance 


\section{LISTA DE SIGLAS}

$\begin{array}{ll}\text { AA } & \text { Alcoólicos Anônimos } \\ \text { ACD } & \text { Auxiliar de Consultório Dentário } \\ \text { ACS } & \text { Agente (s) Comunitário (s) de Saúde } \\ \text { AMA } & \text { Assistência Médica Ambulatorial } \\ \text { APS } & \text { Atenção Primária em Saúde } \\ \text { CAPS } & \text { Centro de Atenção Psicossocial } \\ \text { CDHS } & \text { Centro de Direitos Humanos de Sapopemba } \\ \text { CECCO } & \text { Centro de Convivência e Cooperativa } \\ \text { CEDECA } & \text { Centro de Defesa da Criança e do Adolescente } \\ \text { CID } & \text { Código Internacional de Doenças } \\ \text { CT } & \text { Conselho Tutelar } \\ \text { EGJ } & \text { Espaço Gente Jovem } \\ \text { ESM } & \text { Equipe de Saúde Mental } \\ \text { ESF } & \text { Equipe de Saúde da Família } \\ \text { OMS } & \text { Organização Mundial de Saúde } \\ \text { PAS } & \text { Programa de Assistência a Saúde } \\ \text { PSF } & \text { Programa de Saúde da Família } \\ \text { QUALIS } & \text { Projeto Qualidade Integral em Saúde } \\ \text { SIAB } & \text { Sistema de Informação da Atenção Básica } \\ \text { SMSP } & \text { Secretaria Municipal de São Paulo } \\ \text { SUS } & \text { Sistema Único de Saúde } \\ \text { UBS } & \text { Unidade Básica de Saúde } \\ \text { USP } & \text { Universidade de São Paulo } \\ \text { USF } & \text { Unidade de Saúde da Família }\end{array}$




\section{SUMÁRIO}

APRESENTAÇÃO

CAPÍTULO 1. AS TEMÁTICAS E SUAS INTERFACES COM O CAMPO DA SAÚDE.

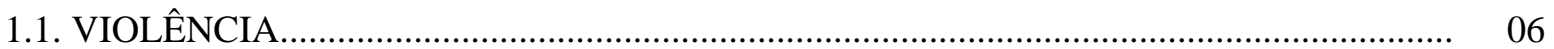

1.2. ÁLCOOL E DROGAS.............................................................................................. 22

1.3. SAÚDE MENTAL ................................................................................................ 30

CAPÍTULO 2. AS TEMÁTICAS NA ATENÇÃO PRIMÁRIA À SAÚDE................ 43

CAPÍTULO 3. PERCURSO TEÓRICO................................................................. 52

3.1. COMUNIDADE E TRABALHO EM SAÚDE........................................................... 52

3.1.1. DELINEANDO O CONCEITO DE COMUNIDADE E SUA APROPRIAÇÃO NO CAMPO DA SAÚDE........................................................................................................ 52

3.1.2. TRABALHO EM SAÚDE E COMUNIDADE NO CONTEXTO DO PSF

3.2. DEMANDAS E NECESSIDADES MÉDICO-SOCIAIS

3.2.1. A CONSTRUÇÃO HISTÓRICA DO CONCEITO E SUA UTILIZAÇÃO NO CAMPO DA SAÚDE COLETIVA

CAPÍTULO 4. OBJETIVOS.

CAPÍTULO 5. METODOLOGIA E ASPECTOS ÉTICOS 68

5.1. DELINEAMENTO DA PESQUISA 68

5.2. CONTEXTO DO ESTUDO E QUESTÕES OPERACIONAIS........................................... 71

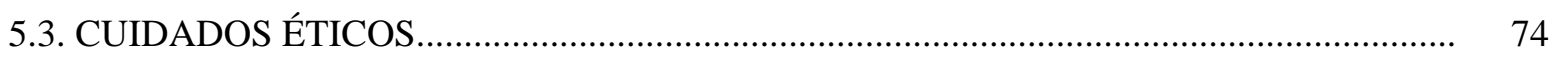

CAPÍTULO 6. ANÁLISE TEMÁTICA DO MATERIAL EMPÍRICO_..................... 75 


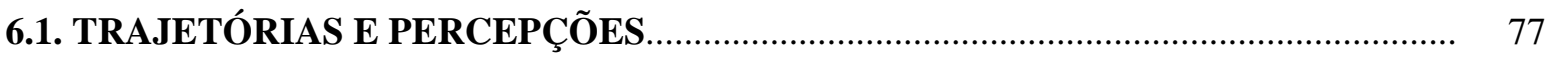

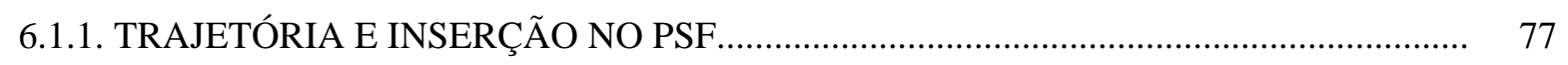

6.1.2. O SERVIÇO DE SAÚDE: ESTRUTURA E FUNCIONAMENTO.................................. 81

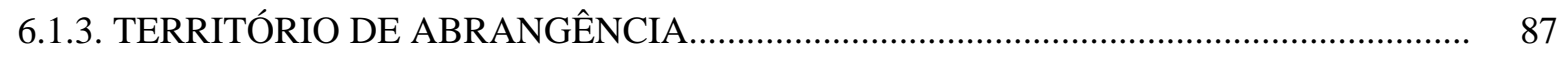

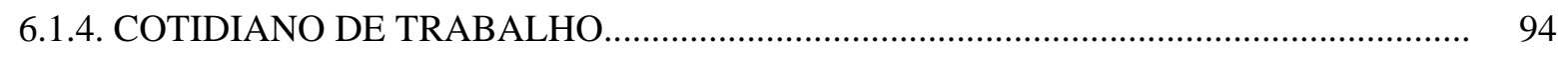

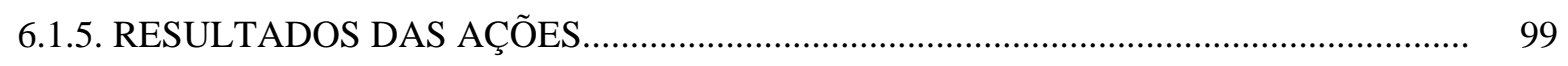

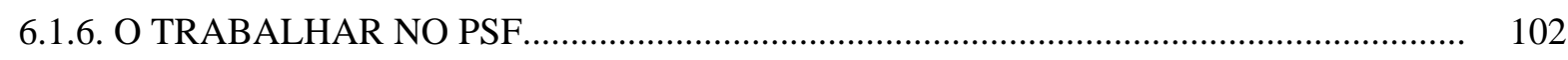

6.2. ‘SERVIÇO DE SAÚDE E COMUNIDADE’ E AS COMPREENSÕES TEMÁTICAS RELACIONADAS ÀS DEMANDAS E NECESSIDADES MÉDICO-SOCIAIS.................. 106

6.2.1. A RELAÇÃO ‘SERVIÇO DE SAÚDE E COMUNIDADE' .............................................. 106

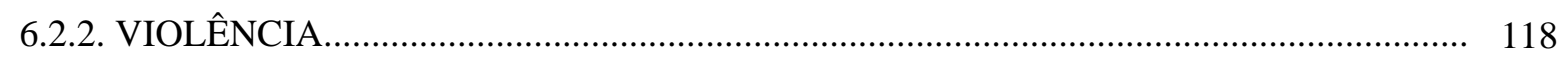

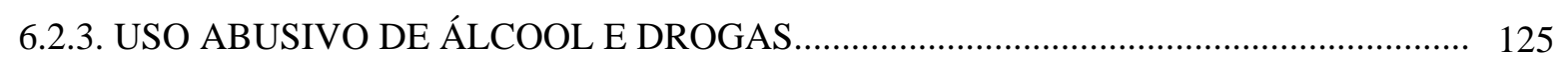

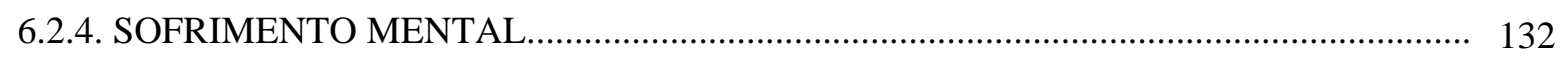

6.3. REPRESENTAÇÕES DE COMUNIDADE NO TRABALHO EM SAÚDE.................. 137

6.3.1. COMUNIDADE: AS PERCEPÇÕES DOS PROFISSIONAIS DA USF............................ 137

6.3.2. LIMITES E POTENCIALIDADES DA RELAÇÃO 'SERVIÇO-COMUNIDADE’ E

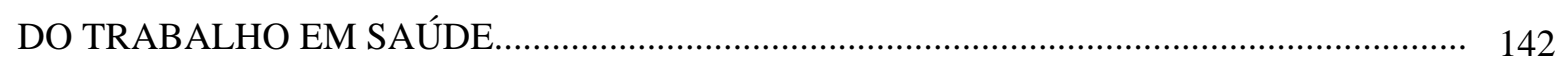

6.3.3. SER PROFISSIONAL DE SAÚDE DIANTE DA COMUNIDADE................................. 145

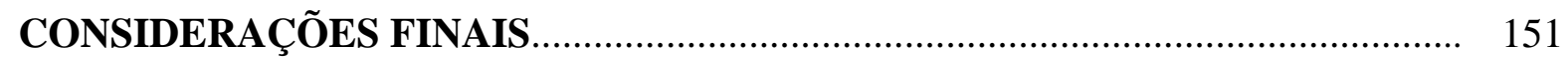

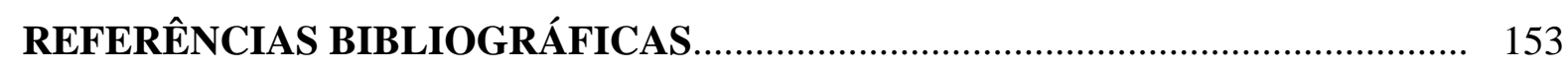

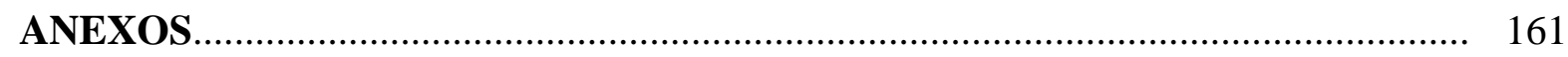

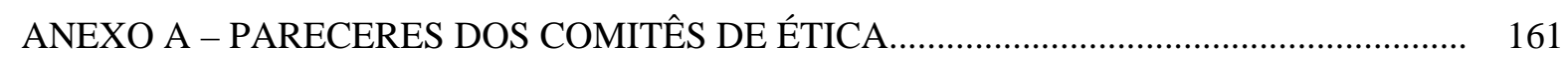

ANEXO B - TERMOS DE CONSENTIMENTO LIVRE E ESCLARECIDO............................ 164

ANEXO C - ROTEIROS DAS ENTREVISTAS E GRUPO FOCAL ….................................. 166

ANEXO D - LISTAGEM DAS ENTREVISTAS E GRUPO FOCAL ….................................. 172 


\section{APRESENTAÇÃO}

A intenção do presente pesquisa está em paralelo à construção de uma experiência profissional.

Desde o curso de graduação em Terapia Ocupacional na Universidade Federal de São Carlos - UFSCar pude realizar estudos e pesquisas relacionados às experiências do Programa de Saúde da Família - PSF, bem como aos grupos populacionais que não são tradicionalmente acolhidos nos serviços de saúde.

A aproximação com estas temáticas ocorreu por acreditar que a formação enquanto terapeuta ocupacional deveria também integrar o campo da saúde pública evidenciando atuações para além das até então tradicionais ocorridas nos níveis secundário e terciário da atenção em saúde.

Neste sentido, baseando-se nas discussões e proposições da Terapia Ocupacional Social $^{1}$, fui a campo em busca de uma terapia ocupacional inserida na atenção primária à saúde, um espaço favorável para as experimentações intersetoriais.

Em 2005, continuei o percurso ao ingressar no Aprimoramento e Especialização em Saúde Coletiva pelo Departamento de Medicina Preventiva da Faculdade de Medicina da Universidade de São Paulo - FMUSP. Este permitiu conhecer um espaço para observações e reflexões sobre a coexistência de modelos em saúde, o que potencializou a formação enquanto profissional do SUS.

Essas experiências possibilitaram a entrada ${ }^{2}$ em uma equipe pioneira na atuação em saúde mental no contexto do PSF no município de São Paulo.

\footnotetext{
${ }^{1}$ A terapia ocupacional social busca um maior compromisso com a população que assiste por meio do conhecimento da sua realidade, das suas necessidades e das maneiras pelas quais as pessoas compreendem o seu mundo e o seu cotidiano. Promove espaço para reflexões das possibilidades e limites da atuação na atenção a grupos sociais em processos de rupturas das redes sociais de suporte, exigindo um perfil profissional aberto às necessidades do outro, esse outro, aliás, contextualizado e em permanente relação com um meio que o produz e é produzido por ele, no qual o terapeuta ocupacional também participa e intervém (BARROS; GHIRARDI; LOPES, 2002; LOPES; PALMA; REIS, 2005).
} 
A Equipe de Saúde Mental (ESM) da região Sudeste, em que me integrei, foi criada com o objetivo de capacitar as Equipes de Saúde da Família (ESF) e prestar assistência às famílias em situação de sofrimento mental da área de abrangência da Unidade Saúde da Família (USF) existente nessa região em 1998 através do Projeto QUALIS/PSF ${ }^{3}$ (LOPES; PALMA, 2005; SOUSA, 2007).

Pelos anos de implantação desta equipe ao me aproximar das ESF e, principalmente, dos agentes comunitários de saúde (ACS) já acostumados a terem um espaço aberto para escuta e discussão de situações/casos do território, fui 'bombardeada' por inúmeros depoimentos, questionamentos, solicitações e desabafos.

No decorrer do trabalho, as ações em conjunto com profissionais também moradores da comunidade, as constantes visitas domiciliares, o trabalho em equipe na tentativa de integrar diferentes linguagens e o estar propriamente no território diante da comunidade me conduziram dar continuidade à formação e desenvolver outros estudos. De certo modo, também queria perpetuar um espaço aberto para questionar, solicitar e até mesmo acalmar as angústias diante da ilusória missão de ser ‘solucionadora’ antes mesmo de ser um profissional de saúde possuidor de limites.

Portanto, assumi o desafio: integrar as passagens de aluna para trabalhadora em saúde e desta para pesquisadora em um curto período de tempo se comparado às riquezas das aproximações, aprendizados e encontros.

\footnotetext{
${ }^{2}$ A mestranda atuou no Programa de Saúde Mental do PSF da Secretaria Municipal de Saúde de São Paulo como terapeuta ocupacional no período de novembro/2005 a março/2008.

${ }^{3}$ Com a implantação do PAS em 1996, o município de São Paulo não aderiu ao SUS. Desse modo, em abril de 1996, a tríplice parceria (Ministério da Saúde, Secretaria Estadual da Saúde de São Paulo e a entidade filantrópica conveniada ao SUS - Casa de Saúde Santa Marcelina) favoreceu o início da implantação do PSF na região Leste do município com a denominação Projeto Qualidade Integral em Saúde - QUALIS, o QUALIS I. A partir desta experiência, a Fundação Zerbini em outubro de 1997 ampliou o projeto, o QUALIS II. Também houve a implantação de novos serviços e programas atrelados à equipe nuclear, dentre eles, o Programa de Saúde Mental (LOPES; PALMA, 2005).
} 
O trabalho no PSF provocou muitas reformulações no projeto desta pesquisa, dada às complexidades de situações/casos deparados cotidianamente: a mulher que ia escondida para ‘desabafar' as violências que sofria por causa dos ciúmes do marido; as mães 'órfãs' deprimidas por terem perdido seus filhos para o tráfico; a vizinhança que pedia ajuda para mulher 'louca' que deixava os quatro filhos pequenos na rua; os constantes pedidos da agente comunitária para visitar a família em que o pai abusava sexualmente da filha adolescente; as reuniões em que a equipe aguardava respostas para o cuidado de dois irmãos que há muitos anos faziam uso abusivo de álcool; as dificuldades de efetivar laços com a rede de serviços em saúde. Além do repetitivo momento, denunciando impotências, quando uma agente comunitária de cabelos brancos perguntava: E os meninos? E os jovens que usam drogas? Não vamos fazer nada?

Outros questionamentos ressoavam: Como agir diante de tamanha complexidade? O trabalho em saúde comporta tudo? É meu, seu ou nosso? A relação com a comunidade é tão apregoada como estruturante do trabalho, mas quando a obtemos e nos aproximamos das histórias de vida e família o que fazemos com ela? A aproximação ou não da equipe de profissionais com a comunidade influencia a explicitação de suas demandas e necessidades?

Em meio às subjetividades, onipotências, impotências e muitas histórias, procurei dar voz às questões que ficavam veladas, aquelas que eram ditas rapidamente e na forma de 'desabafo', ou aquelas mais preocupantes que nas trocas de informações nos corredores de unidade por lá se perdiam.

Problematizo neste estudo três temáticas: a violência; o uso abusivo de álcool e drogas; e o sofrimento mental. A escolha se deve primeiro: pela recorrência delas no cotidiano do trabalho trazidas prioritariamente à USF pelos ACS. Segundo, por 'provocarem' árduas discussões sobre as estratégias e intervenções da ESF denunciando limites e potencialidades. 
Por fim, pelas complexidades em que estão implicadas e por serem constituídas no território da intersetorialidade, sendo, assim, pertinentes também ao setor Saúde.

A pesquisa pretende discutir como estas temáticas, aqui tomadas e compreendidas enquanto demandas e necessidades médico-sociais, de uma comunidade situada na periferia do município de São Paulo são percebidas, incorporadas e influenciadoras do trabalho em uma USF; além de compreender como esta se aproxima, acolhe e intervém, enfim, se relaciona diante das mesmas.

Diante de situações e cenários singulares presentes no cotidiano de práticas do PSF, evidenciados pela grande proximidade com as histórias de vida familiar e comunitária, pude levantar questionamentos e preocupações que conduziram o meu olhar para a proposta de trazer à cena as representações de comunidade para o trabalho em saúde, bem como a permeabilidade da relação ‘serviço de saúde e comunidade’ através da incorporação (ou não) de demandas e necessidades médico-sociais sob a perspectiva dos profissionais de saúde de diferentes formações em suas atuações cotidianas.

É neste contexto somado à trajetória acadêmica ${ }^{4}$ e à prática profissional que emerge o tema: As representações de comunidade para o trabalho em saúde.

O capítulo I aproxima-se da discussão das temáticas e suas interfaces com o campo Saúde.

Baseando-se em documentos, estudos científicos e revisão de literatura científica em bases dados, as temáticas na atenção primária à saúde são apresentadas no capítulo II.

\footnotetext{
${ }^{4}$ Foram realizadas duas pesquisas que se relacionam ao tema: 1) Lopes e Palma (2005), no subprojeto da pesquisa Ações Básicas de Saúde e a Construção do SUS: Cidadania, Direitos e Políticas Pública (LOPES et al., 2007), discutiram as ações de saúde mental e de saúde da pessoa portadora de deficiência no PSF, assim como as possibilidades e os limites da terapia ocupacional na atenção básica a partir da experiência do Projeto Qualis/PSF - SP. 2) Palma e Couto (2006) investigaram, sob a ótica dos coordenadores do Programa de Saúde do Adulto, a atuação profissional do agente comunitário de saúde inserido em um equipamento de saúde com programas pré-existentes.
} 
O capítulo III traz um percurso teórico sobre comunidade, trabalho em saúde e as demandas e necessidades médico-sociais.

Nos capítulos seguintes, IV e V, encontram-se os objetivos, aspectos éticos e o delineamento metodológico visando à execução da coleta de dados no campo de pesquisa.

A análise temática do material empírico, capítulo VI, apresenta os dados e as análises relativos às trajetórias e percepções, relação ‘serviço de saúde e comunidade’, compreensões temáticas relacionadas às demandas e necessidades médico-sociais e representações de comunidade no trabalho em saúde.

Nas Considerações Finais, destacam-se as dimensões relevantes para estudos complementares tanto no campo da saúde pública e coletiva como no campo social. 


\section{CAPÍTULO 1 - AS TEMÁTICAS E SUAS INTERFACES COM O CAMPO DA SAÚDE}

Apresenta-se, neste capítulo, a delimitação das temáticas: violência, álcool e drogas, e saúde mental.

As temáticas surgem de modo gradual quanto às suas interfaces com o campo da saúde. A primeira evidencia a sua recente interface com o campo, já as demais, pela tamanha aproximação, são até detidas por alguns como pilares constituintes deste campo.

\subsection{VIOLÊNCIA}

A recorrência da palavra violência no cotidiano, na mídia, nos estudos científicos e nas formulações de pensadores de diversas áreas de conhecimento denota sua propriedade polissêmica. O uso pode ser acompanhado tanto pela carga ideológica, preconceituosa e/ou de senso comum quanto pelas definições que vão desde as formas mais cruéis de tortura e de assassinatos em massa até aspectos mais sutis e disseminados, considerados opressivos na vida moderna, tais como as relações sociais, econômicas e as normas culturais (MINAYO; SOUZA, 1998; D’ OLIVEIRA, 2000).

No Novo Dicionário Aurélio da Língua Portuguesa, encontra-se a palavra 'violência' significando ato violento; qualidade de violento; constrangimento físico ou moral; uso da força; e, coação. Destaca-se a palavra 'violento', que é definida como: aquele que age com ímpeto; que se exerce com força; agitado e tumultuoso; irritadiço; em que se faz uso de força bruta; e, o que é contrário ao direito e à justiça (FERREIRA, 2004).

Apreendendo essas características da palavra, vejamos o que alguns autores discutem acerca do conceito violência.

Yves Michaud (1989), filósofo francês, considera que:

há violência quando, numa situação de interação, um ou vários atores agem de maneira direta ou indireta, maciça ou esparsa, causando danos a uma ou várias pessoas em graus variáveis, seja em sua integridade física, seja em sua integridade moral, em suas posses, ou em suas participações simbólicas e culturais (p.10-11). 
Porto (2002) partilha dessa elaboração e aponta a vantagem de permitir uma abordagem da violência a partir das diferentes dimensões (material e simbólica) que constituem a vida social. Entretanto, discute a imprecisão sobre a intencionalidade ou não do agente. Isto é, traz os questionamentos:

Será a intencionalidade do ato condição sine qua non para a existência de violência? Será a premeditação um requerimento para a existência de intencionalidade? A definição [proposta por Michaud] não chega a esclarecer totalmente essas dúvidas. Embora se possa admitir que sim, que estes seriam requerimentos necessários para que se possa concluir pelo caráter violento de uma dada ação, não se pode deixar de considerar as muitas circunstâncias em que atos com desfechos violentos e com danos reais a uma ou mais pessoas possam ser incluídos no rol dos chamados resultados não previstos da ação (p.152-153).

À complexidade da questão da causalidade soma-se a dificuldade conceitual, que pode decorrer também pelo fato da violência ser um fenômeno empírico antes do que um conceito teórico. Assim, é retirado diretamente da realidade social que descreve permitindo a apropriação de um conceito por vários outros campos que não o científico (PORTO, 2002).

Alba Zaluar (1999), pesquisadora e coordenadora do Núcleo de Pesquisa em Violências (NUPEVI) do Instituto de Medicina Social da Universidade do Estado do Rio de Janeiro, relaciona o significado da palavra à força e destaca a concepção cultural e histórica como caracterizadoras quando um ato é ou não violento.

violência vem do latim violentia que remete a vis (força, vigor, emprego de força física ou os recursos do corpo para exercer sua força vital). Essa força torna-se violência quando ultrapassa um limite ou perturba acordos tácitos e regras que ordenam relações, adquirindo carga negativa ou maléfica. É, portanto, a percepção do limite e da perturbação (e do sofrimento que provoca) que vai caracterizar o ato como violento, percepção essa que varia cultural e historicamente (p.28).

Esta percepção dialoga com a dimensão simbólica, presente na elaboração de Michaud, a qual abre espaço para a variabilidade histórico-cultural.

aquilo que, em um dado momento, numa dada sociedade, é considerado como violência varia segundo a natureza da sociedade considerada, configurando a realidade empírica da violência como um fenômeno polissêmico e plural. A rigor, não faz sentido falar em violência no singular, já que estamos confrontados com manifestações plurais de violência, cujas 
raízes e efeitos, igualmente múltiplos, apontam a existência de tipos diferenciados de violência (PORTO, 2002, p.153).

Outro pesquisador, Sérgio Adorno (2003), ao debater sobre o conceito sintetiza três elementos, características que se relacionam à violência. São eles:

1. Modo de ser: a violência designa uma maneira de ser da força, do sentimento ou de um elemento natural (por exemplo, a violência de uma paixão, a violência da natureza). Reporta-se à força brutal ou desmedida que desrespeita regras e convenções;

2. Fatos, representações, explicações: a. a violência diz respeito à modalidades estagnadas que se opõem à paz, à ordem; b. é um conceito normativo que se referindo ao mundo dos valores constituem o 'sagrado' para determinado grupo social (comunidade, sociedade, civilização); c. embora não exija uma justificativa, aguarda explicação científica;

3. Contexto histórico e interação social: a violência está em relação com o social e o cultural, envolve atores, agências (instituições), situações (contextos), meios, estruturas normativas (valores). Não envolve apenas dois adversários, e sim, múltiplos grupos com suas particularidades e com suas identidades.

Esses elementos possibilitam compreender a presença de interações conflitivas, as quais remetem às idéias de assimetria nas relações de poder, de hierarquias que implicam sujeição/subordinação, de heteronomia ${ }^{5}$ em lugar de autonomia. Ou seja, a violência favorece o emprego arbitrário da força, por ator/atores, posicionados hierarquicamente e de forma assimétrica, com o propósito de impor sua vontade contra a de outros (ADORNO, 2003).

Voltando-se para o documento publicado em 2002 pela Organização Mundial de Saúde - OMS, encontramos o modelo ecológico aplicado para compreender a natureza multifacetada da violência. Ele ajuda a esclarecer as causas de violência e suas complexas

\footnotetext{
${ }^{5}$ Entende-se por heteronomia, a condição de pessoa ou de grupo que receba de um elemento que lhe é exterior, ou de um princípio estranho à razão, a lei a que se deve submeter (FERRARI, 2004).
} 
relações recíprocas, além de examinar fatores que influenciam o comportamento, ou que aumentam o risco de cometer ou de ser vítima de violência (KRUG et al., 2002).

O modelo ecológico para compreender a violência é separado em quatro níveis:

$1^{\text {o }}$. Individual: marcado pela identificação de fatores biológicos e pessoais que influenciam o comportamento dos indivíduos e aumentam a probabilidade de se tornarem vítimas ou perpetradores de atos de violência;

$2^{\circ}$. Relações societárias: examina como as relações estreitas (entre família, amigos, parceiros íntimos) aumentam o risco de ser vítima ou autor de violência;

$3^{\circ}$. Comunidade: examina os contextos comunitários das relações sociais buscando as características dos contextos que aumentam o risco de violência;

$4^{\circ}$. Sociedade: examina fatores gerais da sociedade que favorecem o encorajamento ou inibição da violência (KRUG et al., 2002).

Esses níveis podem ser vistos como quatro círculos sobrepostos indicando a idéia de que os fatores de cada um podem reforçar ou modificar o outro nível. Sugere-se, portanto, que há uma necessidade de agir em vários níveis diferentes ao mesmo tempo para se evitar a violência (KRUG et al., 2002).

No documento da OMS, a tipologia utilizada classifica a violência por natureza do ato violento (física, sexual, psicológica ou implicando privação ou negligência) e por quem comete o ato: auto dirigida (conduta suicida e auto-abuso); interpessoal (subdividida em violência familiar e íntima e violência comunitária) e coletiva (exercida por grupos para atingir objetivos políticos, econômicos ou sociais) (KRUG et al., 2002; ADORNO, 2003).

Existem outras possibilidades de tipologia da violência como, por exemplo, segundo: 
a). à natureza: crime urbano (comum e organizado); violações de direitos humanos ${ }^{6}$ (violência policial, violência institucional, execuções sumárias, assassinatos de lideranças, linchamentos e graves violações de direitos econômicos, sociais, políticos e culturais), violência nas relações intersubjetivas ${ }^{7}$ e violência simbólica;

b). à participação dos atores: individual, coletiva e institucionalizada ou não;

c). às origens: estrutural (desigualdades sócio-econômicas e políticas) e agentes e agências; e,

d). à natureza do dano: física, psíquica, sexual e moral (ADORNO, 2003).

Minayo num esforço de instigar o tema para a reflexão científica traz uma classificação bastante geral, mas que não se reduz aos conceitos. Apresenta categorias enquanto um processo de causas múltiplas e causalidade não-linear, de natureza e características específicas e gerais, micro e macrossociais, que se diferenciam e se articulam (SOUZA, 1993; MINAYO, 1994; SCHRAIBER; D’OLIVEIRA; COUTO, 2006).

Assim, temos as seguintes definições:

- violência estrutural: aplica-se tanto às estruturas organizadas e institucionalizadas da família como aos sistemas econômicos, culturais e políticos que levam à opressão de grupos, classes, nações e indivíduos, tornando-os mais vulneráveis ao sofrimento e à morte devido à negação de conquistas da sociedade;

- violência da resistência: reporta-se às diversas reações dos grupos, classes, nações e indivíduos oprimidos pela violência estrutural. Geralmente não é 'naturalizada', pelo

${ }^{6}$ Compreendem direitos, formalizados no contexto do estado liberal democrático (séc.XIX), à vida e às liberdades civis públicas, os quais implicam obrigação por parte do Estado de garanti-los, inclusive o acesso à plena justiça em caso de abusos praticados seja por civis, seja por autoridades públicas. Sabe-se que nos últimos duzentos anos, há um alargamento desses direitos para o campo dos direitos econômicos, sociais e políticos, inclusive direitos de grupos com identidades singulares, além do direito ao meio-ambiente (ADORNO, 2003).

7 A violência nas relações intersubjetivas, em geral, envolve tensões, conflitos entre pessoas conhecidas desfechando na morte de um dos contendores, às vezes até acidental e inesperadamente. Pode-se dizer, portanto, que são: “conflitos entre companheiros e suas companheiras, entre parentes, entre vizinhos, entre amigos, entre colegas de trabalho, entre conhecidos que freqüentam os mesmos espaços de lazer, entre pessoas que se cruzam diariamente nas vias públicas, entre patrões e empregados, entre comerciantes e seus clientes” (ADORNO, 2002, p.07). 
contrário, é objeto de contestação e repressão por parte dos detentores do poder político, econômico e/ou cultural;

- violência da delinqüência: constitui-se a partir das diversas formas de delito (roubo, furto, assassinatos, seqüestros, brigas entre quadrilhas, etc.) se revelando nas ações fora da lei socialmente reconhecida. É a forma mais conhecida e reconhecida como violência (SOUZA, 1993; MINAYO, 1994).

Discutindo essa última categoria, Minayo (1994) expõe a necessidade de compreendêla a partir da violência estrutural.
A análise deste tipo de ação [violência da delinqüência] necessita passar pela compreensão da violência estrutural, que não só confronta os indivíduos uns com os outros, mas também os corrompe e impulsiona ao delito. A desigualdade, a alienação do trabalho e nas relações, o menosprezo de valores e normas em função do lucro, o consumismo, o culto à força e o machismo são alguns dos fatores que contribuem para a expansão da delinqüência. Portanto, sadismos, seqüestros, guerras entre quadrilhas, delitos sob a ação do álcool e de drogas, roubos e furtos devem ser compreendidos dentro do marco referencial da violência estrutural, dentro de especificidades históricas (p.08).

Sabe-se que a preocupação em entender a essência desse fenômeno numa busca de atenuá-lo, preveni-lo e eliminá-lo da convivência social existe desde os tempos imemoriais, "um eterno problema da teoria social e da prática política e relacional da humanidade” (MINAYO, 1994, p.07).

Atualmente, a violência é vista tanto nos espaços públicos e privados, nas relações institucionais, grupais ou interpessoais como em tempos de guerra ou de suposta paz. Diante deste amplo domínio, não há elementos e conhecimentos suficientes para enfrentá-la e para identificar as interconexões que a alimentam (SCHRAIBER; D’OLIVEIRA; COUTO, 2006).

Schraiber, D’Oliveira e Couto (2006) discutem a crise da sociabilidade, a "falência dos processos vigentes de socialização dada pelas dificuldades contemporâneas em manter a socialidade diante do domínio crescente da violência” (p.113). 
O centro da crise surge dos impasses em lidar com a liberdade no exercício de direitos sociais e humanos conectado com compromissos sociais e responsabilidades éticas e civis. Estes impasses são expressos por um paradoxal alargamento da noção de direitos, configurado pelo borramento de limites em seu exercício, resultante da desconexão com a esfera relacional. Ou seja, situa-se cada vez mais como questão individual silenciando as contrapartidas relacionais: os deveres e os compromissos (SCHRAIBER; D'OLIVEIRA; COUTO, 2006).

As autoras explicam que:

nessa equivalência o outro pouco importa, associando-se a liberdade de exercício de direitos à coisificação desse outro, ruptura interativa que fundamenta as violências. Estabelece-se um agir de ambivalência ética, perpassado por valores móveis, substituindo escalas de valores, delimitadas e definidas, por uma agenda de valores fluída, maleável conforme as oportunidades (quase sempre de mercado) e, pois, sem possibilidade de permanência no tempo. Trata-se de uma 'adoção' de valores adaptável aos desejos e ao próprio alargamento do que venham a ser ou não direitos (SCHRAIBER; D’OLIVEIRA; COUTO, 2006).

Em tempos de crise de sociabilidade e reiteradas manifestações de violência, Porto (2002) observa que a mobilização da sociedade civil reivindicando o fim da impunidade e a vigência de padrões mais solidários de relações e interações sociais em prol da não-violência pode contribuir para uma ressignificação da violência ao não aceitar eufemismos para definila e de nomear como violência atos e comportamentos que eram, há até bem pouco tempo, considerados formas ou conteúdos corriqueiros de regulamentação social.

Pode-se apreender que os conhecimentos e discussões sobre o tema permitem inferir, no entanto, alguns elementos consensuais e, ao mesmo tempo, compreender o quanto este é controverso, em quase todos os seus aspectos (MINAYO, 1994).

Diante da complexidade e do dinamismo desse fenômeno, o qual é assumido aqui como problema histórico, fenômeno social e indicador de qualidade de vida; apontaremos para sua relação com a saúde. Para tanto, afastam-se visões reducionistas que o tratam como 
uma ‘epidemia’ e que o consideram como um processo a-histórico, linear, e acima das consciências e da sociedade.

\section{VIOLÊNCIA E SAÚDE}

A violência não é objeto próprio do setor Saúde; entretanto, torna-se parte dele a partir do impacto que provoca na qualidade de vida; das lesões físicas, psíquicas e morais que acarreta; das exigências de atenção e cuidados dos serviços médico-hospitalares; e também, da concepção ampliada de saúde, compreendendo a violência como objeto da intersetorialidade, na qual o campo médico-social se integra (MINAYO, 2004).

Segundo Deslandes (2002), diversas formas de violência afetam diretamente o campo da saúde ferindo a cidadania e a qualidade de vida dos indivíduos e populações, seja pelo elevadíssimo número de mortes que provoca, seja pelas inúmeras vítimas que constituem demanda imediata e complexa de cuidados médicos, psicológicos, de reabilitação, dentre outros.

Apesar dessas inter-relações, somente em 1993 a Organização Pan-Americana da Saúde - OPAS diante das mudanças nos perfis de morbimortalidade na maioria das regiões latino-americanas passou a recomendar oficialmente aos seus países membros a inclusão do tema violência na agenda de intervenção (MINAYO, 2004).

Dada a gravidade da situação em outras partes do mundo para além das Américas, em 1997 a OMS dedicou prioridade ao tema na Assembléia Mundial de Saúde. E, em 2002, publicou o denominado Relatório Mundial sobre Violência e Saúde (citado anteriormente), que traz para a área uma reflexão sobre sua responsabilidade específica e intersetorial, além de dar ênfase à produção contínua de conhecimentos científicos visando subsidiar o estabelecimento de políticas públicas para o seu enfrentamento (MINAYO, 2004; BRASIL, 2005a). 
Schraiber, D’Oliveira e Couto (2006) destacam a relevância desta publicação pela OMS. Primeiro, por ser um movimento internacional, que torna público e mundial a questão da violência possibilitando a ampliação do debate e permitindo a construção de referências para os diversos movimentos regionais. Segundo, por valorizar e resignificar o problema violência, além de lhe conferir um todo: “unifica-se a violência enquanto questão a ser enfrentada, ao mesmo tempo, que se definem as distintas violências enquanto diversidades dessa questão plural” (p.114).

A reorientação quanto ao modo tradicional de tratar diagnósticos de saúde das populações, presente neste Relatório, destaca as mortes por causas externas, aquelas por violência, os homicídios e os suicídios, associando-os aos dados de morbidade. Nos estudos de Schraiber, D’Oliveira e Couto (2006) também é acompanhada pelas novas possibilidades de aproximação ao problema, surgindo, ao lado das referidas desigualdades socioeconômicas, outras iniqüidades, tais como as de gênero e as de raça/etnia.

Outro ponto a ser destacado neste Relatório é a reorientação firmada em críticas a conceitos tradicionais explicativos da violência: família, geração, classe social ou identidades de bases nacionais, que parecem, agora, insuficientes para lidar com o problema (SCHRAIBER; D’OLIVEIRA; COUTO, 2006).

Direcionando o olhar para o Brasil, sabe-se que apesar de desde 1980 o tema Acidentes e Violências se constituírem a segunda causa de óbito no perfil da mortalidade geral, a sua introdução na agenda da política de saúde foi extremamente difícil (MINAYO, 2004; BRASIL, 2001).

Os acidentes e as violências constituem um conjunto de agravos à saúde, que pode ou não levar ao óbito, no qual se incluem as causas ditas acidentais (as relacionadas ao trânsito, trabalho, quedas, envenenamentos, afogamentos e outros tipos de acidentes) e as causas intencionais (agressões e lesões autoprovocadas) (MINAYO, 2004; BRASIL, 2001). 
Mesmo assim, o tema passou a ser cada vez mais evidenciado e publicizado por pesquisadores e estudiosos do conceito e das informações sobre 'causas externas', nota que designa as mortes, as lesões e os traumas derivados da violência na Classificação Internacional de Doenças - CID (MINAYO, 2004).

E logo após a Assembléia Mundial de Saúde que privilegiou o assunto, em 1998 o Ministério da Saúde - MS criou um Comitê Técnico com a finalidade de diagnosticar e propor ações específicas para o setor. Isto resultou na elaboração da Política Nacional de Redução da Morbimortalidade por Acidentes e Violências, aprovada pela Portaria MS/GM nº 737, de 16 de maio de 2001(MINAYO, 2004; BRASIL, 2001).

Este instrumento contém definição dos conceitos, diagnóstico da situação, diretrizes e estratégias de ação intersetorial, além de responsabilidades institucionais, que contemplam medidas ligadas à promoção da saúde e à prevenção mediante o estabelecimento de processos de articulação com os diferentes segmentos da sociedade (MINAYO, 2004; BRASIL, 2001).

Segundo os autores Souza, Lima e Veiga (2005), a violência diante do seu crescimento passou a ser apropriada pelo campo da saúde como objeto de reflexão de pesquisadores da saúde coletiva. Assim, diversas teorias explicativas e técnicas metodológicas têm sido utilizadas objetivando esclarecer a questão em termos de sua magnitude e impacto de sua prevalência e incidência, ou seja, em uma perspectiva epidemiológica.

Demonstrando aspectos das interfaces, violência e saúde, citaremos aqui alguns dados obtidos em documentos, estudos e publicações científicas relacionados aos grupos e populações considerados de risco.

Segundo levantamento sobre os estudos que discutem violência e saúde, sabe-se que na década de 1990, a maioria baseou-se na premissa de que a violência vem crescendo, já que desde 1980 as causas externas ocupam o segundo lugar entre as causas de morte no país. 
Logo, quem dá nome e presença à violência, marcada enquanto violência entre homens, são as causas externas (SCHRAIBER; D’OLIVEIRA; COUTO, 2006).

Já na metade da década de 1990, houve o decréscimo das publicações e uma mudança significativa de enfoque. Os pesquisadores direcionaram o foco aos adolescentes e adultos jovens ao analisar a correlação entre as condições de vida e as taxas de homicídios. E a violência estrutural, resultante da metropolização, da deteriorização urbana e das desigualdades nas condições de vida, foi o marco analítico utilizado (SCHRAIBER; D’OLIVEIRA; COUTO, 2006).

Estudos apontam que o homicídio foi a causa que mais contribuiu para o crescimento da mortalidade por violências e acidentes no país. Alguns dados: 40\% dos homicídios atingem a população produtiva com idades entre 20 e 39 anos; 78\% dos homicídios são provocados pelo uso de armas de fogo, contra 11\% por arma branca; e, o Brasil apresenta a média de 24,9 homicídios por 100 mil habitantes, pelo menos quatro vezes maior que a média mundial (BRASIL, 2003; SOUZA; LIMA; VEIGA, 2005).

No Brasil, a taxa de homicídios cresceu mais de 115\% nos últimos 20 anos, sendo que somente 8\% dos crimes cometidos são esclarecidos (BRASIL, 2003).

Assinala-se que, em 1997, para cada mulher de 20 a 29 anos de idade, morreram 15 homens da mesma faixa etária por projétil de arma de fogo. A população masculina, além de armas de fogo está também mais exposta a outros fatores de risco, como o uso de álcool e drogas (BRASIL, 2001).

Documentos apontam que adolescentes e jovens são os mais afetados pela violência. A mortalidade tem como principal causa os eventos violentos: cerca de sete, em cada 10 adolescentes, morrem por causas externas, homicídios, acidentes e suicídios (BRASIL, 2001, 2003). 
O período 2000-2005 apresentou um crescimento do número de publicações; pesquisadores selecionam cidades específicas e tratam o aumento da mortalidade por causas externas, como produto, sobretudo, da taxa de homicídios, evidenciando ser este um dos maiores problemas atuais da saúde pública (SCHRAIBER; D’OLIVEIRA; COUTO, 2006).

Marsiglia, Silveira e Carneiro Jr (2005) evidenciam em estudo que a morbimortalidade por acidentes e violências têm crescido rapidamente entre os mais pobres nas regiões metropolitanas em virtude dos processos de exclusão e de abandono sociais pelas precárias condições de trabalho, desemprego, falta de perspectiva de trabalho e de vida, crime organizado, narcotráfico, arbitrariedade policial, entre outros.

Temos um quadro marcado por acentuado avanço tecnológico, discrepante distribuição de renda e desigualdade social que contribui para aumentar o número dos excluídos. Em um mundo regido pela valorização do consumo, as 'faltas', a falta de emprego, a fome, a frustração e a insegurança, tornam brasileiros mais violentos e vulneráveis à prática de ilícitos penais (BRASIL, 2003).

Como visto, esses dados exemplificam a presença de uma forte tendência da incorporação de fenômenos sociais relacionados às desigualdades, à pobreza e ao desemprego na construção de modelos sobre causalidades das altas taxas de mortes violentas (SOUZA; LIMA; VEIGA, 2005). Contudo, é importante salientar que as relações entre violência e condições de vida não são fáceis de serem descritas, pela complexidade e heterogeneidade que estão presentes.

Crianças, adolescentes e jovens (indivíduos na faixa etária de zero a 24 anos de idade) são vítimas de diferentes tipos de acidentes e de violências (BRASIL, 2001).

Na infância, o principal local onde são gerados agravos é o ambiente doméstico, já na adolescência, o espaço extra-domiciliar tem prioridade no perfil epidemiológico. A partir desta distinção, pode-se estabelecer a classificação estratégica: 
- acidentes domésticos (quedas, queimaduras, intoxicações, afogamentos e outras lesões) e acidentes extra-domiciliares (acidentes de trânsito e de trabalho, afogamentos, intoxicações e outras lesões); e,

- violências domésticas (maus-tratos físicos, abuso sexual e psicológico, negligência e abandono) e violências extra-domiciliares (exploração do trabalho infanto-juvenil e exploração sexual, além de outras originadas na escola, na comunidade, nos conflitos com a polícia, especialmente caracterizados pelas agressões físicas e homicídios), bem como as violências auto-infligidas (tentativa de suicídio) (BRASIL, 2001).

A gravidade da violência doméstica que ocorre com crianças manifesta-se tanto nas conseqüências imediatas quanto tardias, tais como rendimento escolar deficiente e alteração do processo de crescimento e desenvolvimento. Estudos evidenciam que a mortalidade de crianças pode ser um indicador de violência doméstica, pois é nessa faixa etária que se detectam mortes ocorridas no lar (BRASIL, 2001).

A violência contra a criança e o adolescente é potencializadora da violência social, estando presente na origem de situações como o aumento da população em situação de rua, da prostituição infantil e o envolvimento em atos infracionais (BRASIL, 2001).

Cerca de 15 milhões de crianças fazem das ruas brasileiras o seu espaço de sobrevivência. Meninos e meninas, sem um lar, uma alimentação adequada e, sobretudo, sem proteção e amor, desenvolvem mecanismos que lhe proporcionam a ilusória realização de seus desejos: $85,5 \%$ dos casos de abuso sexual de crianças e adolescentes decorrem da exploração comercial e o consumo de drogas e a violência constituem reações contra a insegurança causada pelo abandono, ausência de limites e de valores éticos (BRASIL, 2003).

A violência física e psicológica são as formas de violência familiar que mais afetam o crescimento e o desenvolvimento de crianças e adolescentes. Ressalta-se o abuso sexual, que na maioria dos casos é praticado por pessoas da própria família. Essas situações 
comprometem, geralmente, a capacidade de relacionamento, produzem seqüelas profundas e contribuem para uma cultura de violência na sociedade (BRASIL, 2003).

Cruz-Neto e Moreira (1998) discutem sobre as precárias condições de vida de crianças e adolescentes que não têm acesso à escola ou trocam as salas de aula pelo trabalho. Inseridos precocemente no 'mercado de trabalho', estes jovens realizam variadas atividades, desde o setor primário da economia até a chamada 'economia informal' incluindo ramos ilegais como tráfico de drogas e prostituição.

Em muitos casos esse acréscimo de dinheiro que arrecadam com o trabalho, que é precário, significa a única fonte de renda para eles e suas famílias. Em contrapartida, a infância e adolescência são vivenciadas longe da escola, dos cuidados médicos e do acesso aos direitos, e o pior, transformam-se em adultos sem maiores perspectivas (CRUZ-NETO; MOREIRA, 1998).

No segmento populacional representado pelas mulheres, as violências físicas e sexuais são as mais freqüentes, cujos determinantes estão associados principalmente às relações de gênero, estruturadas em bases desiguais e que reservam a elas um lugar de submissão. Sabe-se que em sua grande maioria os agressores são conhecidos, sendo identificados como maridos, companheiros e parentes próximos (BRASIL, 2001).

Os nomes dados à violência que as mulheres sofrem são muitos: violência familiar ou intrafamiliar; violência doméstica, violência nas relações amorosas e conjugais, violência contra a mulher, violência de gênero. Essas denominações guardam referências não apenas do lugar de origem, mas marcam os enfoques teórico-analíticos e políticos arrolados para a compreensão e ação diante da problemática (COUTO; SCHRAIBER, 2005).

As desigualdades nas oportunidades de trabalho e renda, vergonha, medo ou falta de apoio jurídico, psicológico e social fazem com que muitas mulheres respondam às agressões com o silêncio, o que contribui para aumentar a impunidade (BRASIL, 2003). 
Os idosos, pessoas a partir dos 60 anos de idade, constituem outro grupo que sofre violência. Esta pode ser manifesta sob diferentes formas: abuso físico, psicológico, sexual, abandono, negligência, abuso financeiro e auto-negligência (BRASIL, 2001).

A negligência, conceituada como recusa, omissão ou ineficácia em satisfazer qualquer parte das obrigações ou deveres para com um idoso, é uma forma de violência presente tanto no espaço doméstico quanto no institucional, resultando muitas vezes em comprometimento físico, emocional e social, e até mesmo no aumento dos índices de morbidade e mortalidade (BRASIL, 2001).

Os idosos são vítimas de preconceitos, abandono e agressões físicas e morais por não terem um papel nas atividades produtivas numa sociedade tão competitiva e excludente que não valoriza a sua participação. Infelizmente, as leis que deveriam protegê-lo são desconhecidas e estão entre as mais desrespeitadas pela sociedade em geral (BRASIL, 2003).

E nessa linha de raciocínio, ao separarmos em grupos para identificação e discussão das formas de violência, pode-se perceber que há muitos discriminados. Pessoas acometidas por transtornos mentais, portadores de deficiência, vítimas da Aids, mulheres, negros, índios, homossexuais e profissionais do sexo tornam-se alvos fáceis de intolerância, preconceito e a falta de respeito (BRASIL, 2003).

Apesar do uso compatibilizado para apresentação dos dados, entende-se que a violência não pode ser tratada apenas em suas diferentes dimensões: como um problema de saúde contra crianças, adolescentes, mulheres, idosos, discriminados. Ela deve também ser analisada em cada uma dessas dimensões destacando sua própria complexidade e especificidade, que ao serem problematizadas detalhadamente permitem melhor conhecimento e, portanto, propiciam indícios mais precisos para intervenções e formulações de políticas públicas (MORGADO, 2006). 
Muitas ações de nível nacional, estadual e municipal de prevenção à violência e aos acidentes estão em curso, algumas existem antes da portaria que define a política, e outras, inspiradas nela. Apesar disso, Minayo (2004) considera que tudo tem sido muito lento e há vários motivos para isso:

O principal é que, numa área dominada pela mentalidade biomédica, 'as violências e os acidentes' costumam ser vistos como um objeto estranho a seu universo conceitual. Porém, é preciso que todos saibam que o perfil de mortalidade e da morbidade da população brasileira é marcado mais pelas condições, situações e estilos de vida do que pelas enfermidades tradicionais Violências e acidentes fazem parte desses problemas que devem merecer tanta atenção como a AIDS, o câncer e as enfermidades cárdio-vasculares (p.646).

Outro ponto levantado por Schraiber, D’Oliveira e Couto (2006) é que embora haja diversidade de abordagens nas pesquisas e explorações sobre tema, destacam-se algumas importantes ausências: segmentos populacionais específicos e enfoques relevantes deixam de ser tratados, tais como raça/etnia e gênero.

Se de um lado, isto mostra a complexidade do próprio tema, cujas expressões concretas e particulares exigem grande dispersão de tratamento, de outro lado, entende-se que os estudos sobre violência e saúde encontramse, ainda, em momento inicial de sua produção (SCHRAIBER; D’OLIVEIRA; COUTO, 2006, p.118).

Tomando o conjunto das considerações feitas, a necessidade de reflexões e intervenções sobre o objeto violência (que ainda se mostra inicial) esbarra na dificuldade da delimitação precisa e consensual, porém se coloca enquanto uma grande questão para o campo da saúde pela presença marcante de suas inter-relações, bem como a complexidade, sobretudo quanto a rede de relações que se estabelece entre múltiplos atores (DURAND, 2005).

Portanto, pode-se dizer que no plano internacional e nacional, a violência é reconhecida como questão social e de saúde pública; além de ser considerada violação de direitos, embora com expressões variadas em diferentes contextos (SCHRAIBER; D' OLIVEIRA; COUTO, 2006). 


\subsection{O USO ABUSIVO DE ÁLCOOL E DROGAS}

Um em cada cinco homens busca na droga ‘algo diferente' do que está acostumado a ver, pensar e sentir. A oferta é imensa, desde os produtos naturais até milhares de substâncias sintéticas produzidas por laboratórios, oficiais ou não, sem contar as que são consumidas pelos denominados 'intoxicados menores', que necessitam de tabaco, café, colas, etc. (BAPTISTA, 2005).

As drogas são substâncias que atuam sobre um ou mais sistemas do organismo e produzem alterações em seu funcionamento (age nas sensações, no grau de consciência e no estado emocional). Estas alterações variam de acordo com as características de quem as usa, o tipo de droga escolhida, a quantidade, a freqüência, as expectativas, e as circunstâncias em que é consumida (LARANJEIRA; NICASTRI, 1996; BRASIL, 2005b).

Substâncias psicoativas ou drogas psicotrópicas são as outras formas para nomear as drogas. A primeira se refere à atuação diretamente sobre o Sistema Nervoso Central - SNC, ocasionando alterações no estado normal de vigília e senso-percepção. Em linhas gerais, é subdividida pelo efeito mais proeminente em: estimulantes, depressoras ou perturbadoras (alucinógenas, psicodislépticas ${ }^{8}$ ) do SNC. Já a segunda, é quando uma substância ou produto, além do seu efeito psicoativo, tem o potencial de provocar dependência (LARANJEIRA; NICASTRI, 1996; PRÓ-REITORIA DE DESENVOLVIMENTO UNIVERSITÁRIO, 2008).

Sabe-se que o uso pode ser definido como qualquer consumo de substância (experimental, esporádico ou episódico); abuso ou uso nocivo como consumo com o objetivo de obter efeito psicoativo recreativo, sem qualquer indicação terapêutica ou orientação médica, e já está associado a algum tipo de prejuízo (biológicos, psicológicos ou sociais); e, por fim, dependência, o consumo sem controle ocasionando geralmente sérios problemas nos mais diferentes setores da vida (LARANJEIRA; NICASTRI, 1996; PRDU, 2008).

\footnotetext{
${ }^{8}$ Diz respeito à substância que produz efeito(s) semelhante(s) ao(s) de psicose (FERREIRA, 2004).
} 
A dependência de drogas é marcada pela necessidade do uso constante para que o indivíduo possa se sentir bem, evitando assim os sintomas de abstinência. A vida gira em torno de como obter a droga, desencadeando enormes perdas sociais e afetivas, além dos danos à saúde. Em geral, existe também algum tipo de dependência física e/ou psicológica (PRDU, 2008).

Apesar da idéia de evolução contínua (uso, abuso e dependência), as classificações modernas (DSM-IV e CID 10) ${ }^{9}$ consideram o abuso como uma categoria residual, em que a dependência não pôde ser caracterizada de uma forma clara. Outro ponto destacado é que as classificações atuais de distúrbios provocados por substâncias psicoativas fornecem critérios ou diretrizes para diagnóstico que são gerais, ou seja, independem da substância consumida para a caracterização de abuso ou dependência (LARANJEIRA; NICASTRI, 1996; PRDU, 2008).

Sabe-se que a experiência com substâncias psicoativas se dá ao longo da história humana. Durante muito tempo o uso baseava-se estritamente em plantas, através do consumo direto e depois retirando o princípio ativo do vegetal. Alguns exemplos que temos são: a cocaína, a maconha, a morfina, a mescalina e a psilocibina (CHASSAING, [2007?]; PROGRAMA ÁLCOOL E DROGAS, 2008).

Com a matriz natural, drogas semi-sintéticas começaram a ser obtidas em laboratório. A mais conhecida é a heroína obtida através da molécula de morfina (PAD, 2008).

Drogas totalmente obtidas em laboratório, sem a necessidade de precursores naturais, foram produzidas a partir do ano de 1920. O desenvolvimento das anfetaminas e barbitúricos marcaram o início dessa nova fase (CHASSAING, [2007?]; PAD, 2008).

\footnotetext{
${ }^{9}$ Sistemas classificatórios, o primeiro desenvolvido pela Associação Psiquiátrica Americana, o Diagnostic and Statistical Manual - DSM - of Mental Disorders, em sua $4^{\text {a }}$ edição. O segundo, pela OMS, a Classificação Internacional de Doenças - CID, na sua 10ª edição (JORGE, 1996).
} 
A partir de 1980, houve a modificação das moléculas das drogas sintéticas com finalidades específicas, como potencializar, evitar determinados efeitos ou combinar novas sensações. Foi nessa época que as ‘designer drugs’ ou ‘club drugs' - em especial o MDMA (ecstasy) - ganharam notoriedade, por meio do seu consumo nas danceterias e festas 'tecno' chamadas de 'raves’(CHASSAING, [2007?]; PAD, 2008).

Na maioria dos países, a droga psicoativa mais utilizada é o álcool; tanto para a celebração como para o sofrimento. Considerado a companhia nos eventos sociais, na maior parte das vezes implica riscos relativamente baixos para quem bebe ou terceiros. Por outro lado, pode acarretar danos graves nas esferas sociais e individuais (STRONACH, 2004).

Estudos mostram que depois do tabaco, o álcool é a segunda maior causa de mortes relacionadas às drogas. Se comparado com as drogas ilícitas, ele tem um impacto ainda maior em termos de mortes, ferimentos e custos econômicos (STRONACH, 2004).

Em qualquer estágio de doença, em todos os grupos etários, de maneira direta e indireta, o álcool tem impactos. Acidentes de carro traumáticos, violências e agressões, atividade sexual não planejada ou não desejada, conflitos com a lei ou com o patrão podem decorrer do consumo de álcool em curto prazo. Já o prejuízo aos órgãos físicos como o coração e o fígado, as perdas de relacionamentos familiares e de emprego, os problemas financeiros são resultados do exagero de consumo ou de compulsão à bebida por um período maior de tempo (STRONACH, 2004).

Em vários países do Leste Europeu, um grupo de defensores da abordagem anti-álcool, identifica qualquer uso de álcool como alcoolismo ou alcoolismo em potencial. Porém, essa abordagem tem sido considerada ineficiente ao ser confrontada com as afirmações de médicos e pesquisadores que defendem o uso moderado de álcool por adultos saudáveis, já que este pode contribuir para o bem-estar, boa saúde, e até mesmo para a prevenção de várias doenças (OSIATYNSKA, 2004). 
Para muitos, o fato de o consumo de álcool ser legal na maioria dos países significa que, de certa forma, ele é mais seguro que as outras drogas. Porém, legalidade não confere segurança (STRONACH, 2004).

Do ponto de vista legal, as drogas no Brasil se dividem em lícitas ou ilícitas. As drogas lícitas (álcool, tabaco, cafeína) possuem permissão do Estado para serem comercializadas e consumidas; já as ilícitas (cocaína, maconha, LSD e heroína) não podem ser consumidas e muito menos comercializadas, pelo menos com a anuência do Estado (PAD, 2008).

A seguir, são apresentados alguns dados de documentos sobre drogas ilícitas no Brasil.

A substância proibida por lei mais usada em nosso país é a maconha. Segundo pesquisa realizada em 2001, de cada 100 brasileiros, sete já haviam usado maconha pelo menos uma vez na vida (ou seja, 7\%). Este dado varia conforme o sexo e a idade: entre homens, 10,6\% já usaram e, entre mulheres, 3,4\%. Jovens adultos entre 18 e 34 anos de idade, atingem o maior uso (9\%) e o menor é o dos adolescentes entre 12 a 17 anos (3,5\%) (BRASIL, 2005b).

Dois entre cada cem brasileiros relataram ter usado cocaína pelo menos uma vez na vida. Este dado varia bastante conforme sexo e idade: $4 \%$ são homens e $1 \%$ mulheres, sendo que a faixa etária de maior uso se concentra entre os 25 e os 34 anos de idade, na qual atinge a porcentagem de 4,4\% (BRASIL, 2005b).

Não há dados suficientes para saber se o uso de cocaína ou de outras drogas está estável, diminuindo ou aumentando na população como um todo. No entanto, entre estudantes da rede estadual de ensino, pesquisados regularmente em dez capitais do país, constatou-se que o uso de cocaína vem aumentando: em 1987, 0,5\% dos estudantes de quinta série ao ensino médio relataram que já tinham usado cocaína; em 1989 a porcentagem subiu para 0,7\%, em 1993 para 1,2\% e em 1997, foi para 2,0\% (BRASIL, 2005b). 
Quanto ao 'crack', um novo jeito de preparar e usar a cocaína, menos de 1\% dos brasileiros já teve algum contato com a droga; homens experimentam mais do que as mulheres; e a maior porcentagem de uso se encontra na faixa etária de 25 a 34 anos (BRASIL, 2005b).

O ‘crack’ ou ‘pedra’, denominação dada por usuários brasileiros, tornou-se popular na em meados da década de 90 do século XX. A pedra unitária consumida por via oral, fumada em cachimbo, tem preço mais acessível do que a cocaína em pó. Mas a impressão de economia é ilusória: a pedra tem uma quantidade mínima de substância ativa, que é muito menor do que o pó. Além disso, seus efeitos são mais pronunciados e prejudiciais devido à liberação da cocaína diretamente na corrente sanguínea através dos pulmões (BRASIL, 2005b).

Enquanto o ‘crack’ ganhou popularidade em São Paulo, a merla passou a ser mais usada no Distrito Federal, de onde se espalhou para o norte e nordeste do país. A merla (mela, mel ou melado) é a cocaína apresentada sob a forma de base ou pasta, um produto ainda sem refino e muito contaminado com as substâncias utilizadas na extração (BRASIL, 2005b).

Sabe-se que depois do álcool e do tabaco, as primeiras drogas a serem usadas por adolescentes são solventes ou inalantes (cola, benzina, éter, gasolina, acetona). Cerca de 6\% dos brasileiros já inalaram algum desses produtos (BRASIL, 2005b).

Somando o preço acessível e a grande disponibilidade, os inalantes tornam-se muito usados entre crianças e adolescentes em situação de rua. E os jovens adultos tendem a usá-los na forma de lança-perfume ou 'loló’, mistura de éter com aromatizantes (BRASIL, 2005b).

Um ponto que merece destaque por se relacionar com esses dados é o comércio de drogas que tem a violência como sua face mais perversa.

Falta de perspectivas de escolarização, qualificação profissional, trabalho remunerado e de atividades de lazer, esporte e cultura, estão entre as causas que levam milhares de jovens 
a ingressarem nas redes da contravenção e serem 'adotados' pelo tráfico, um sistema ilegal e isento de impostos que movimenta bilhões de dólares por ano no mundo, tendo o Brasil sua parcela de participação (BRASIL, 2003a).

O uso de álcool e outras drogas tomou proporção de grave problema de saúde pública no país; encontrando ressonância nos diversos segmentos da sociedade, principalmente, pela "relação comprovada entre o consumo e agravos sociais que dele decorrem ou que o reforçam” (BRASIL, 2003b, p.05).

De acordo com a OMS, aproximadamente 10\% das populações dos centros urbanos de todo o mundo, consomem abusivamente substâncias psicoativas. Isto evidencia que o enfrentamento dessa problemática constitui-se enquanto uma demanda mundial (BRASIL, 2003b).

Historicamente, produziu-se uma importante lacuna na política de saúde brasileira, por esta não ter se posicionado devidamente diante do grave problema de prevenção e tratamento de transtornos associados ao consumo de álcool e outras drogas, deixando esta incumbência para as instituições da justiça, segurança pública, pedagogia, benemerência e associações religiosas (DELGADO et al., 2007).

Com a relativa ausência do Estado diante desse complexo problema, houve uma disseminação de ‘alternativas de atenção’ baseadas em uma prática psiquiátrica ou médica, de caráter total, fechado, ou, ainda, de cunho religioso. O principal objetivo a ser alcançado: a abstinência (DELGADO et al., 2007).

A formação dessa rede de instituições, a maioria filantrópica, apontou a necessidade de posicionamentos claros e incisivos pelas políticas de saúde pública para combater o problema. Entretanto, o que predominou foi a percepção distorcida da realidade quanto ao uso de álcool e outras drogas, principalmente, por não serem consideradas as implicações sociais, psicológicas, econômicas e políticas, uma compreensão global (DELGADO et al., 2007). 
[Assim,] acabou por promover a disseminação de uma cultura que associa o uso abusivo de drogas à criminalidade e que combate as substâncias que são inertes por natureza, fazendo que o indivíduo e o seu meio de convívio fiquem aparentemente relegados a um plano menos importante. Isto, por vezes, é confirmado pela multiplicidade de propostas e abordagens preventivas/terapêuticas consideravelmente ineficazes e por vezes reforçadoras da própria situação de uso abusivo e/ou dependência (DELGADO et al., 2007, p.71-72).

Como visto o uso de álcool e outras drogas associava-se à criminalidade, às práticas anti-sociais e à oferta de 'tratamentos' inspirados em modelos de exclusão/separação dos usuários do convívio social; ou seja, não havia uma política de alcance nacional no âmbito da saúde pública (DELGADO et al., 2007).

Somente em 2002, o MS elabora o Programa Nacional de Atenção Comunitária Integrada aos Usuários de Álcool e outras Drogas, reconhecendo o uso prejudicial de substâncias como importante problema de saúde pública, além de construir uma política pública específica para a atenção às pessoas que fazem o uso de álcool ou outras drogas (DELGADO et al., 2007).

Em 2003, o MS divulgou o documento intitulado: A política do Ministério da Saúde para a Atenção Integral a usuários de Álcool e outras Drogas, que inicia a discussão sobre a implantação de serviços de atenção à saúde (MORAES, 2008).

A partir desse documento e outros oficiais, a política pública da redução de danos passa a ser citada com maior destaque no Brasil. Esta se opõe à visão tradicional de redução da oferta e embasada em dois argumentos:

1) é impossível uma sociedade completamente sem drogas; 2) a guerra às drogas contraria os princípios éticos e direitos civis das pessoas, ferindo o direito à liberdade do uso do corpo e da mente. Além disso, a abordagem da redução de danos põe em ação estratégias de autocuidado imprescindíveis para diminuição da vulnerabilidade frente à exposição às situações de risco, além de ser apontada como forma privilegiada de intervenção em saúde pública (MORAES, 2008, p.123).

A implantação de programas e ações pautadas nessa abordagem ainda é alvo de críticas e censuras, gerando polêmicas e contradições de várias ordens (MORAES, 2008). 
No entanto, prevenir o uso indevido de álcool e outras drogas constitui em ação de inquestionável exigindo especial atenção tanto do Poder Público como da sociedade nos mais diversos contextos - família, escola, comunidade, empresa (SENAD, 2007).

Atualmente, a Secretaria Nacional Antidrogas - SENAD é o órgão responsável por coordenar as políticas relacionadas ao uso de drogas. Criada pela Medida Provisória nº 1669 e pelo Decreto $\mathrm{n}^{\mathbf{0}}$ 2.632, ambos de 19 de junho de 1998, e subordinada ao Gabinete de Segurança Institucional da Presidência da República, desenvolve e apóia a realização de estudos e pesquisas para aprofundar o conhecimento sobre drogas e as ações desenvolvidas nas áreas de prevenção, tratamento, redução de danos sociais e a saúde e ensino e pesquisa (SENAD, 2007; 2008; MORAES, 2008).

Isto vai ao encontro da necessidade de construir um panorama geral sobre o uso de drogas na sociedade brasileira, que até então esbarra nos limites colocados pela defasagem dos instrumentos de coleta de informações, como também, entre outros fatores, pelo aspecto ilícito e marginalizado do uso de algumas substâncias (MORAES, 2008).

\section{Compete também à SENAD:}

exercer a secretaria-executiva do Conselho Nacional Antidrogas - CONAD; articular e coordenar as atividades de prevenção do uso indevido, a atenção e a reinserção social de usuários e dependentes de drogas; propor a atualização da política nacional sobre drogas na esfera de sua competência e gerir o FUNAD [Fundo Nacional Antidrogas] e o Observatório Brasileiro de Informações sobre Drogas (SENAD, 2008).

Segundo os resultados do Mapeamento das instituições governamentais e nãogovernamentais de atenção às questões relacionadas ao consumo de álcool e outras drogas no Brasil, realizado pela SENAD em parceria com a Universidade de Brasília (UnB), verifica-se que entre os conteúdos abordados o álcool e a maconha são as drogas mais pesquisadas, e os aspectos médicos e levantamentos (pesquisas epidemiológicas) os assuntos gerais mais explorados (SENAD, 2007). 
Outro ponto levantado no Mapeamento diz respeito à constatação da carência de pesquisadores e centros de excelência para a formação de estudiosos nas áreas de álcool e outras drogas no Brasil. Urge suprir essa deficiência, dada à relevância médica, social e epidemiológica que envolve a pesquisa sobre álcool e outras drogas (SENAD, 2007).

Por fim, compreende-se o uso abusivo de álcool e drogas como um fenômeno histórico-cultural com implicações médicas, políticas, religiosas e econômicas; sendo preciso no campo da atenção à saúde de pessoas percorrer caminhos para concretizar uma atenção integral, justa e humanizada (MINAYO; DESLANDES, 1998).

Ou seja,

[rompendo] com práticas enraizadas na sociedade, pautadas na psiquiatria do século XIX e na percepção de que os desviantes devem estar 'controlados' dentro das unidades de tratamentos, seja pelo uso de medicamentos, seja pela busca incessante da abstinência (MORAES, 2008, p.132).

Assim, o desafio que se coloca para a saúde pública é conseguir construir um quadro referencial para a reflexão e a ação, englobando ao mesmo tempo o individual, o social e o ecológico (MINAYO; DESLANDES, 1998).

\subsection{A SAÚDE MENTAL}

Nos séculos XVIII e XIX, a história da loucura é quase sinônima à história de sua captura pelos conceitos de 'alienação' e, mais tarde, de 'doença mental' (TORRE; AMARANTE, 2001).

Uma nova experiência do fenômeno da loucura até então vista como característica da desrazão do sujeito é produzida com o princípio do confinamento e da normatização do sujeito louco no asilo (TORRE; AMARANTE, 2001).

No processo de apropriação da loucura pela medicina o conceito de alienação tem um papel estratégico, no momento em que torna-se sinônimo de erro; algo não mais da ordem do sobrenatural, de uma natureza estranha à razão, mas uma desordem desta. A alienação é entendida como um distúrbio das paixões humanas, que incapacita o sujeito de partilhar do pacto social (TORRE; AMARANTE, 2001, p.74). 
Se a alienação é um distúrbio das paixões, logo o seu tratamento torna-se a reeducação moral, ou tratamento moral, conforme designado por Philippe Pinel (1745-1826). O ‘alienado’ pode recobrar a razão e tornar-se sujeito de direito somente após um processo pedagógico-disciplinar realizado no interior do hospício. Este internamento é tido como terapêutico, não caracterizando uma violência à exclusão da cidadania (TORRE; AMARANTE, 2001).

A história do asilamento da loucura e de sua medicalização e patologização abrem espaço para a transformação do conceito em doença mental. Esta é concebida pelo saber psiquiátrico como a causadora da degeneração, sem nenhuma ligação com as formas de relação institucional que se estabelece com a loucura e o louco (TORRE; AMARANTE, 2001).

Desde o surgimento da psiquiatria no final do século XVIII, esta se propunha como disciplina médica à terapêutica dos ‘distúrbios mentais’, abrangendo o estudo destas doenças e das indicações de seus instrumentos curativos. Entretanto, na modernidade, o seu objeto teórico passa a ser outro: a psiquiatria objetiva saber sobre a saúde mental, as suas condições de possibilidade e as formas de estabelecê-la originariamente nos indivíduos (BIRMAN; COSTA, 1994).

Sabe-se que há uma complexidade no processo saúde-doença que ultrapassa o orgânico simples. Logo, o que parece desvio em relação a uma norma, se mostra como outra forma de linguagem, outras subjetividades, outros caminhos neurais e de aprendizagem cultural. A grande questão é que muitas vezes insistimos em desqualificar diante aos modos padronizados de experiência.

Na doença há uma construção de subjetividade diversa, por isso não se trata o sintoma, trata-se o sujeito. Isto propõe um novo raciocínio: a doença deve ser repensada como fato cultural e como caminho; o delírio pode ser necessário como processo; é preciso aprender 
com a doença; ao invés de um tempo e espaço absolutos, uma temporalidade e uma espacialidade produzidos.

Vê-se, portanto, uma transformação,

uma mutação radical no campo epistemológico da Medicina Mental, passando de instrumento de cientificidade sobre a Doença Mental para pretender-se definidor da Saúde Mental. Pode-se, através, de um hábil jogo de palavras, subestimar a transformação operada, (...), ao indicar que quando se queira curar a doença buscava-se à saúde, e que, na modernidade, a psiquiatria levou os seus pressupostos à radicalidade. Entretanto, do ponto de vista teórico, transforma-se o discurso psiquiátrico, e, do ponto de vista assistencial, as suas estruturas se transformam (BIRMAN; COSTA, 1996, p. 43).

A saúde mental, expressão detentora de muitos significados, num primeiro sentido traz a idéia de campo de atuação ou campo de conhecimentos relacionados à saúde mental das pessoas. É uma área de conhecimento e de ações abrangentes caracterizada pela inter e transdiciplinariedade e intersetorialidade, onde saberes como: medicina, psicologia, antropologia, filosofia, etc., se entrecruzam (LANCETTI; AMARANTE, 2007).

A OMS reconhece a sua importância e a explora em sua definição de saúde: “como 'não simplesmente a ausência de doença ou enfermidade', mas como 'um estado de completo bem-estar físico, mental e social’” (OMS, 2001, p.02).

Em virtude dos progressos nas ciências nos últimos anos, esta definição ganhou foco mais nítido ao considerar a amplitude e complexidade das práticas e teorias relacionadas à saúde mental. Ou seja, houve um aumento da compreensão sobre o funcionamento mental e o relacionamento entre saúde mental, física e social (OMS, 2001).

Segundo a OMS (2001), as doenças e os distúrbios relacionados à saúde mental são denominados transtornos mentais e comportamentais, ou seja, são condições caracterizadas por alterações do modo de pensar e do humor (emoções) ou por comportamentos associados com angústia pessoal e/ou deterioração do funcionamento. Podem apresentar quadro variado e heterogêneo: brandos ou graves, de curta ou longa duração, discerníveis por um exame minucioso, ou impossíveis de ocultar a um observador casual. 
Neste sentido, para categorizar como transtorno, é preciso que esses componentes sejam sustentados, recorrentes e que resultem em certa deterioração ou perturbação do funcionamento pessoal em uma ou mais esferas da vida (OMS, 2001).

Importante salientar que nem toda deterioração humana denota distúrbio mental. Os indivíduos podem sofrer angústia em virtude de circunstâncias pessoais ou sociais, bem como, modos de pensar e se comportar entre diferentes culturas podem influenciar a maneira pela qual se manifestam os transtornos mentais, embora não constituam, em si mesmos, indicações de distúrbio. Assim, variações normais determinadas pela cultura não devem ser rotuladas como transtornos mentais. Da mesma forma, crenças sociais, religiosas ou políticas não podem ser tomadas como indicações de distúrbio mental (OMS, 2001, p.18).

Outro ponto que merece destaque é que toda classificação de transtornos mentais e de comportamentos propõe diagnósticos e classifica síndromes e condições, mas não indivíduos. Embora sofram um ou mais transtornos durante um ou mais períodos da vida, não se deve usar uma ‘etiqueta diagnóstica’ para descrever um indivíduo (OMS, 2001).

O impacto negativo da estigmatização e da discriminação está presente em todas as partes do mundo, entretanto, isto não pode ser um impedimento para os portadores de transtornos mentais e comportamentais terem uma vida plena e produtiva, em sua respectiva comunidade (OMS, 2001).

Como visto anteriormente, pesquisadores e estudiosos de diversas culturas podem dar diferentes definições à saúde mental. Os conceitos abrangem: o bem-estar subjetivo, a autoeficácia percebida, a autonomia, a competência, a dependência intergeracional e a autorealização do potencial intelectual e emocional da pessoa (OMS, 2001).

Já na perspectiva transcultural, delimitar o conceito de saúde mental de uma forma completa é uma tarefa quase que impossível. Mas, há consenso quanto ao fato de que é algo mais do que a ausência de transtornos mentais (OMS, 2001).

Brevemente, destacaremos fatos marcantes do processo histórico da saúde mental no Brasil relacionando alguns fatos e/ou dados mundiais. 
Nos anos 70 do século XX, a internação em hospícios e asilos manicomiais e, consequentemente, a exclusão do convívio social das pessoas com transtornos mentais, passou a ser fortemente questionada pelo movimento da Reforma Psiquiátrica (MACHADO, 2005).

Embora contemporânea ao processo da Reforma Sanitária, que avançou se consagrando na Constituição de 1988, e, posteriormente, no advento do Sistema Único de Saúde - SUS, com a Lei 8080, de 1990, o processo da Reforma Psiquiátrica tem história própria, inscrita em um contexto de superação de violência asilar (MACHADO, 2005; DELGADO et al., 2007).

Surge nessa cena, o Movimento dos Trabalhadores em Saúde Mental - MTSM, que apoiado tanto pelo Centro Brasileiro de Estudos da Saúde (Cebes), fundado em 1976 e que reunia o pensamento crítico que lideraria a Reforma Sanitária, como pelo Movimento de Renovação Médica (Reme) ligado ao Sindicato dos Médicos, inicia um processo de lutas (RAMOS, 2004).

O movimento formado por profissionais da área, pacientes e familiares ganhou força e suas ações começaram a ter visibilidade com a I Conferência Nacional de Saúde Mental e o II Congresso Nacional de Trabalhadores de Saúde Mental, ambos em 1987. Este último, sediado na cidade de Bauru-SP, tinha como secretário da saúde o médico sanitarista David Capistrano da Costa Filho (1948-2000), ativo militante das duas reformas que posteriormente viria ser secretário e prefeito de Santos-SP (MACHADO, 2005).

O movimento mostrou que não bastava humanizar os hospícios, melhorar o ambiente manicomial, ou ampliar o número de profissionais dessas instituições; defendia uma idéia mais ampla marcada por um novo lema: Por uma Sociedade sem Manicômios (MACHADO, 2005; DELGADO et al., 2007). 
em lugar dos manicômios, (...) trazer o 'louco' de volta ao convívio social, resgatar a cidadania dos que passaram anos de suas vidas trancafiados, sofrendo maus tratos e humilhações (MACHADO, 2005, p.11).

Neste sentido, a I Conferência Nacional representou o início da trajetória de desconstrução das formas de lidar com a loucura no cotidiano das instituições e da sociedade. É a chamada desinstitucionalização, estabelecendo novas ações: não apenas macrorreformas, mas a preocupação com a atuação em saúde; não apenas instituições psiquiátricas, mas a cultura, o cotidiano. Além de incorporar aliados: os 'pacientes’ e seus familiares, que passam a ser impulsionadores do processo (TENÓRIO, 2002).

Baseando-se nas teses de Franco Basaglia (1924-1980), precursor da reforma psiquiátrica italiana, ocorre a possibilidade de ruptura com os antigos paradigmas, como, por exemplo, na Colônia Juliano Moreira, enorme asilo com mais de dois mil internos no início dos anos de 1980, no Rio de Janeiro (DELGADO et al., 2007).

No Estado de São Paulo, a partir de 1983, através da Coordenadoria de Saúde Mental (CSM), o Governo Franco Montoro assumiu uma política cujo objetivo era diminuir o número de internações psiquiátricas. Assim, foi feito um grande investimento para a ampliação do número de ambulatórios em todo o estado e das equipes em unidades básicas na Grande São Paulo (BARIÇÃO, 2001).

Importante ressaltar que entre os anos de 1984 a 1986, a Divisão de Ambulatórios de Saúde Mental da CSM desenvolveu uma série de iniciativas para a capacitação dos profissionais que compunham as equipes, através de cursos, supervisões clínicas, institucionais e programáticas. Paralelamente, os ambulatórios criaram o Programa de Intensidade Máxima (PIM) para o atendimento de egressos de hospitais psiquiátricos (BARIÇÃO, 2001).

Apesar do investimento nas unidades extra-hospitalares, em especial nos PIMs, foi avaliada a necessidade de estruturas de serviço intermediário entre o hospital e o Ambulatório 
que pudessem oferecer um grau de acolhimento maior e respostas terapêuticas mais complexas para pessoas com transtornos mentais severos (BARIÇÃO, 2001).

Passam a surgir novas propostas e ações para a reorientação da assistência. São de especial importância o surgimento do primeiro Centro de Atenção Psicossocial (CAPS), no município de São Paulo, em 1987, e o início do processo de intervenção em hospital psiquiátrico, em 1989, o que culminou no fechamento da Casa de Saúde Anchieta, local de maus-tratos e mortes de pacientes, no município de Santos (TENÓRIO, 2002; DELGADO et al., 2007).

Assim, neste período, têm-se a criação de Núcleos de Atenção Psicossocial (NAPS) e de CAPS que serviram de modelo para o país (MACHADO, 2005).

Ainda em 1989, o deputado Paulo Delgado (PT/MG) apresenta ao Congresso Nacional um Projeto de Lei que propõe a regulamentação dos direitos das pessoas com transtornos mentais (modernização da legislação que datava de 1934) e a extinção progressiva dos manicômios no país (MACHADO, 2005; DELGADO et al., 2007).

Paralelamente, em 1990, ocorreu a Conferência Regional sobre Reestruturação da Atenção Psiquiátrica na América Latina, que culminou na Declaração de Caracas feita por legisladores, associações, autoridades sanitárias, profissionais de saúde mental e juristas. Esta previa a reestruturação da atenção psiquiátrica com base na atenção primária à saúde, permitindo a promoção de modelos alternativos de serviço baseados na comunidade e integrados nas redes sociais e de atenção de saúde (OMS, 2001).

Logo, a partir de 1991, o financiamento público das ações em saúde mental no país foi redirecionado para a criação de uma rede extra-hospitalar, tendo prioridade a remuneração do atendimento alternativo à internação e o apoio à substituição da internação em hospital psiquiátrico pela internação em hospital geral (TENÓRIO, 2002). 
É nesta década, que o MS instituiu no plano nacional, no rol dos procedimentos e dispositivos de atenção em saúde mental custeados por verba pública, os NAPS e CAPS. A importância é dada pelo fato de que até então não havia no arcabouço normativo a possibilidade de remuneração e incentivo públicos a outras modalidades de assistência que não as tradicionais (internação e ambulatório de consultas) (TENÓRIO, 2002; DELGADO et al., 2007).

A II Conferência Nacional de Saúde Mental, realizada em 1992, representa outro marco histórico da Reforma, principalmente, pela grande participação dos segmentos sociais envolvidos na questão da saúde mental - 20\% dos delegados à conferência eram representantes dos usuários dos serviços (pacientes) e de seus familiares (TENÓRIO, 2002).

Seu relatório final foi publicado pelo MS e adotado como diretriz oficial para a reestruturação da atenção em saúde mental no país, sendo estabelecidos dois marcos conceituais: a atenção integral e a cidadania. A partir dessa referência, são desenvolvidos o tema dos direitos e da legislação e a questão do modelo e da rede de atenção na perspectiva da municipalização (TENÓRIO, 2002).

Em 1998, o Projeto QUALIS/PSF ${ }^{10}$ do município de São Paulo era coordenado por Capistrano e a equipe de dirigentes tinha acompanhado as experiências de Bauru (1984-1986), e de Santos (1989-1996), o que favoreceu a pioneira inserção de um Programa de Saúde Mental atrelado à atenção primária de saúde. Este era composto por equipes volantes de psiquiatras, assistentes sociais, terapeutas ocupacionais e/ou psicólogos (LANCETTI, 2001).

Somente em 2001, esquecida por 12 anos, a Lei Paulo Delgado é sancionada. A aprovação, no entanto, é de um substitutivo que traz modificações importantes ao texto normativo:

\footnotetext{
${ }^{10}$ Ver nota $n^{\circ}$. 3. Nome fantasia dado à implantação do Programa de Saúde da Família - PSF no município de São Paulo dada à adesão municipal por uma lógica baseada na gestão de cooperativas (PAS) e que rompia com as diretrizes do MS ocasionando o não recebimento de recursos federais do SUS. Assim, o município optou por não participar do SUS durante oito anos, também não implantou o PSF (LOPES; PALMA, 2005).
} 
a Lei Federal 10.216 redireciona a assistência em saúde mental, privilegiando o oferecimento de tratamento em serviços de base comunitária, dispõe sobre a proteção e os direitos das pessoas com transtornos mentais, mas não institui mecanismos claros para a progressiva extinção dos manicômios (DELGADO et al.,2007, p.41-42).

Portanto, com a promulgação da Lei, a Reforma Psiquiátrica Brasileira que se organizou em torno dos princípios de desinstitucionalização e desospitalização, para a garantia dos direitos de cidadania dos portadores de transtornos mentais, ganha um novo impulso (TENÓRIO, 2002; DELGADO et al., 2007).

Embora tardia a promulgação da Lei pode-se dizer que ela protagonizou uma situação interessante ao produzir efeitos antes mesmo de ser aprovada. Nota-se que a transformação da assistência e mesmo do estigma social da loucura ocorreu de forma segura e constante, ainda que lenta, ao longo dos dez anos em que o projeto de lei tramitou sem ser aprovado (TENÓRIO, 2002).

O ano de 2001 foi dedicado à discussão do tema Saúde Mental pela OMS. No âmbito das atividades desenvolvidas vimos a instituição do Dia Mundial da Saúde que teve por tema ‘Cuidar, sim. Excluir, não’ visando combater a exclusão das pessoas que têm doenças mentais ou transtornos cerebrais das comunidades. A apresentação do Relatório Mundial de Saúde 2001 trouxe importantes contribuições para o aprofundamento do conhecimento em saúde mental, bem como suas relações com o campo da Saúde Pública (OMS, 2001).

Como visto, quando a noção de saúde mental surgiu como novo objeto da psiquiatria, estava associada a um processo de adaptação social, denotando um padrão de normalidade externo à singularidade do sujeito e à clínica. E pelo aspecto de crítica ao asilo, essa noção veio se constituir enquanto conceito privilegiado da Reforma.

O lugar estratégico que a expressão saúde mental ocupa hoje no discurso da reforma está relacionado a dois aspectos: servir para denotar um afastamento da figura médica da doença, que não leva em consideração os aspectos subjetivos ligados à existência concreta do sujeito assistido; e servir para demarcar um campo de práticas e saberes que não se restringem à medicina e aos saberes psicológicos tradicionais (TENÓRIO, 2002, p.31). 
Assim, entre os pontos a destacar, estão: a penetração crescente de uma nova mentalidade no campo psiquiátrico; a permanência de diretrizes reformistas no campo das políticas públicas, com postos de coordenação e gerência ocupados por alguns partidários da reforma; a existência de experiências inovadoras com resultados iniciais positivos em diversas regiões do país; a manutenção das experiências mais antigas; os indícios de um novo olhar sobre a loucura no espaço social, um olhar não mais tão fortemente marcado pelos estigmas do preconceito e do medo (TENÓRIO, 2002).

Na parte normativa, além das portarias que deram existência institucional aos NAPS e CAPS (citadas anteriormente), duas portarias mais recentes se destacam. São as que instituem os Serviços Residenciais Terapêuticos - SRT (a 106 e a 1.220, ambas de 2000) (TENÓRIO, 2002; DELGADO et al., 2007).

Os SRT, as residências terapêuticas ou simplesmente moradias, são casas inseridas preferencialmente na comunidade, destinadas a cuidar e servir de moradia para pessoas portadoras de transtornos mentais graves, egressas de internações psiquiátricas de longa permanência, que não possuam suporte social e laços familiares a fim de viabilizar sua reinserção social (TENÓRIO, 2002; DELGADO et al., 2007).

Trata-se de permitir uma moradia assistida, porém fora do ambiente hospitalar, com arquitetura, espaço físico e mobiliário adequados a uma casa às pessoas que se tornaram dependentes de uma instituição asilar. Além de garantir o acompanhamento do processo de reabilitação psicossocial (TENÓRIO, 2002).

No final de 2001, a III Conferência Nacional de Saúde Mental:

consolida a Reforma Psiquiátrica como política de governo, confere aos CAPS o valor estratégico para a mudança do modelo de assistência, defende a construção de uma política de saúde mental para os usuários de álcool e outras drogas, e estabelece o controle social como garantia do avanço da Reforma Psiquiátrica no Brasil (DELGADO et al., 2007, p.43).

Em 2002, o processo de redução de leitos em hospitais psiquiátricos e de desinstitucionalização ganha grande impulsividade, e em 2003 é criado o Programa de Volta 
para Casa considerado um dos instrumentos mais efetivos para a reintegração social das pessoas com longo histórico de hospitalização ao fazer um pagamento mensal de um auxílioreabilitação aos seus beneficiários (DELGADO et al., 2007).

Porém, sabe-se que o processo de implantação e expansão desses serviços é lento e bem recente no Brasil (DELGADO et al., 2007).

O atual movimento da Reforma Psiquiátrica Brasileira desdobrou-se em um amplo e diversificado campo de práticas e saberes. Enquanto valor fundante e organizador deste processo, a cidadania evidencia que o campo da Reforma é, sobretudo, heterogêneo: abarca a clínica, a política, o social, o cultural, as relações com o jurídico, e é obra de discussão de atores muito diferentes entre si (TENÓRIO, 2002).

A ação na cultura tem um lugar estratégico, o denominado Movimento da Luta Antimanicomial, o qual propõe chamar a sociedade para discutir e reconstruir sua relação com o louco e com a loucura. Neste movimento, uma característica marcante é a participação dos agora chamados usuários dos serviços de saúde mental (em lugar de pacientes) e de seus familiares nas discussões, encontros e conferências. E na perspectiva de sua ampliação é instituído o dia 18 de maio como Dia Nacional da Luta Antimanicomial, visando potencializar o poder de aglutinação de maiores parcelas da sociedade em torno da causa (TENÓRIO, 2002).

Convém resgatar que a rede de atenção à saúde mental brasileira é parte integrante do SUS e compartilha de seus princípios, sendo essencialmente pública, de base municipal, com controle social fiscalizador e gestor, e composta pelos serviços: CAPS, SRT, Centros de Convivência, Ambulatórios de Saúde Mental, Hospitais Gerais e experiências inovadoras na rede de atenção primária à saúde (DELGADO et al., 2007). 
Dados da OMS apontam que, na maior parte do mundo, longe está de ser atribuída à saúde mental e aos transtornos mentais e comportamentais a mesma importância dada à saúde física. Em geral, são ignorados ou negligenciados (OMS, 2001).

Cerca de 450 milhões de pessoas sofrem transtornos mentais ou de comportamento, mas apenas uma pequena minoria delas recebe mesmo o tratamento mais básico. Nos países em desenvolvimento, é deixada à maioria das pessoas com transtornos mentais graves a tarefa de carregar como puderem o seu fardo particular de depressão, demência, esquizofrenia e dependência de substâncias. Em termos globais, muitos se transformam em vítimas por causa da sua doença e se convertem em alvos de estigma e discriminação (OMS, 2001, p.02).

Entretanto, sabe-se que governos têm tanta responsabilidade pela saúde mental como pela saúde física de seus cidadãos, assim como gestores finais de qualquer sistema de saúde, precisam assumir a responsabilidade para assegurar a elaboração e implementação de políticas de saúde mental (OMS, 2001).

Outro aspecto relevante é possibilitar, a partir dos vários serviços de saúde mental ou de atenção psicossocial que vêm sendo implantados, a composição de uma rede de comunicação para que possa enriquecê-los e fortalecê-los através de trocas e debates (TORRE; AMARANTE, 2001).

Embora as reformas Psiquiátrica e Sanitária tenham origens semelhantes, seguiram caminhos paralelos esboçando certa distância disciplinar. Entretanto, a efervescência da última década, representada pelos debates e efetivas transformações no âmbito da saúde mental, vem ocorrendo com restrito acompanhamento, elaboração e contribuição instrumental por parte do pensamento da saúde coletiva (ONOCKO-CAMPOS; FURTADO, 2006).

Para os pesquisadores Onocko-Campos e Furtado (2006):

A saúde coletiva em suas vertentes relacionadas à avaliação de serviços e desenvolvimento de pessoal vem ampliando seu espaço na academia sem correlativo aumento de sua utilização nos serviços de saúde mental que, por sua vez, requerem uma necessária adaptação desse instrumental e não a simples extrapolação de categorias já consagradas em outros âmbitos (p.1054). 
Neste sentido, observa-se a necessidade de novos estudos considerando a aproximação entre a saúde coletiva e a saúde mental para a constituição de um campo interdisciplinar de saberes e práticas (ONOCKO-CAMPOS; FURTADO, 2006). 


\section{CAPÍTULO 2 - AS TEMÁTICAS NA ATENÇÃO PRIMÁRIA À SAÚDE}

Documentos e estudos científicos recentes apontam para discussões sobre as temáticas problematizadas no contexto da atenção primária à saúde.

Kronbauer e Meneghel (2005) em seu estudo sobre a prevalência e o perfil da violência de gênero (física, psicológica e sexual) perpetrada contra a mulher pelo parceiro (a) atual ou passado em um serviço de atenção primária concluem que:

as mulheres em situação de violência de gênero procuram mais os serviços
de saúde e falam sobre as violências que sofrem, desde que se dê a elas
condições de acolhimento e de escuta. Portanto, recomenda-se que os
serviços de atenção primária em saúde criem espaços para ouvir, entender e
enfrentar a violência de gênero (p.700).

Mais de $40 \%$ das usuárias de um serviço de saúde da atenção primária relataram violência física pelo menos uma vez na vida por qualquer agressor, sendo a violência doméstica por parceiro ou familiar igual a 34,1\% (SCHRAIBER et al., 2002; SCHRAIBER et al., 2007).

Logo, frente aos inúmeros agravos à saúde (mortes por homicídios, suicídios ou presença de ideação suicida, doenças sexualmente transmissíveis, doenças cardiovasculares, dores crônicas) e às dificuldades de ações preventivas (planejamento familiar, proteção ao HIV/Aids, prevenção a riscos obstétricos, perdas fetais e baixo peso ao nascer) torna-se relevante o reconhecimento da violência entre usuárias de serviços, em particular os de atenção primária (SCHRAIBER et al., 2007).

Moura e Reichenheim (2005) discutem que apesar do crescente reconhecimento da violência no âmbito familiar como um problema de saúde pública nos últimos anos, os profissionais de saúde tendem a subestimar sua importância, sendo ainda muito precária a detecção de casos em serviços de atenção primária, principalmente, dada elevada freqüência do evento. 
Paralelo a isto, outro estudo corrobora essa afirmação. Nunes, Sarti e Ohara (2008) em um serviço de atenção primária, constataram que os profissionais de saúde têm dificuldade para compreender a violência, no contexto em que tem significado para os diversos atores envolvidos, e para reconhecê-la como conseqüência de uma dinâmica relacional complexa.

Sobre isto, discorrem que:

A possibilidade de tornar visível a violência intrafamiliar contra a criança e o adolescente exige dos profissionais de saúde um "novo olhar" para a situação. É necessário pensar a violência num âmbito de relações, dentro de um contexto, e reconhecer que esse fenômeno não é doença do agressor e nem doença da vítima, mas sim a conseqüência de uma dinâmica relacional complexa, tornando-se importante problema social que tem repercussões das quais decorrem agravos à saúde (NUNES; SARTI; OHARA, 2008, p.141).

Outra temática que se coloca é a relacionada ao uso abusivo de álcool e drogas.

Diemen, Kessler e Pechansky (2006) revelam que o aumento significativo de consumidores e dos tipos de drogas usadas têm gerado maior demanda para o tratamento dos problemas relacionados ao abuso ou dependência de drogas, tornando-se cada vez mais um dos conhecimentos necessários para profissionais de saúde.

Minto et al. (2007) trazem a idéia de que a atenção primária é ambiente ideal para ações preventivas e de intervenção antes que o padrão de uso de álcool provoque danos à saúde, sendo que os profissionais de saúde ocupam posição estratégica na identificação, abordagem, monitoramento e repetição de intervenções daqueles usuários cujo padrão de beber acarreta risco ou danos para sua saúde.

Pesquisa realizada pela OMS em contextos de atenção primária, evidencia que os diagnósticos de transtornos mentais mais comuns são: depressão, ansiedade e os relacionados ao uso de substâncias; presentes com um ou mais transtornos físicos (isolados ou em conjunto) (OMS, 2001).

Estudo sobre a associação entre variáveis do contexto familiar e o risco de problemas emocionais/comportamentais em crianças cadastradas em um serviço de atenção primária, identificou número elevado de crianças com sintomas internalizantes, de cuidadoras com 
sintomas de estresse e depressão em nível clínico, além de uma significativa associação entre estresse materno e problema de saúde mental infantil (FERRIOLLI; MARTURANO; PUNTEL, 2007).

Outro ponto levantado pela OMS é quanto a atenção aos jovens. Sugere que esta atenção deva ser coordenada com as escolas e a atenção primária de saúde, abordando a saúde mental e física de uma forma integrada e abrangente, cobrindo questões como: gravidez precoce e não desejada, uso de fumo, álcool e outras substâncias, comportamento violento, tentativa de suicídio e prevenção de HIV e doenças sexualmente transmissíveis (OMS, 2001).

Sabe-se que: “aproximadamente 20\% de todos pacientes atendidos por profissionais de atenção primária de saúde têm um ou mais transtornos mentais e comportamentais” (OMS, 2001, p.17).

O manejo e tratamento de transtornos mentais e comportamentais no contexto da atenção primária possibilitam o acesso a maior número de pessoas. Isto proporciona uma atenção melhor e reduz o desperdício de exames e de tratamentos impróprios ou não específicos. E também diminui a estigmatização ao aproximar o cuidado dos transtornos aos problemas de saúde física; melhora a triagem, o tratamento, e, especialmente, as taxas de deteç̧ão de usuários com queixas somáticas mal definidas; potencializa o tratamento das questões físicas dos que sofrem doenças mentais; e melhora o tratamento dos aspectos mentais associados aos problemas físicos (OMS, 2001).

Para garantir o melhor uso dos conhecimentos apreendidos, detectar e realizar imediata aplicação de intervenções faz-se necessário treinamento nas aptidões essenciais da atenção em saúde mental para profissionais de atenção primária e atenção de saúde geral (OMS, 2001).

Embora a atenção primária ofereça o contexto mais vantajoso para a atenção inicial, há necessidade de especialistas para prover toda uma série de serviços. Em condições ideais, as equipes especializadas em atenção em saúde mental deveriam incluir profissionais médicos e não médicos, tais como psiquiatras, psicólogos clínicos, enfermeiros psiquiátricos, assistentes 
sociais psiquiátricos e terapeutas ocupacionais, que podem trabalhar juntos com vistas à atenção e à integração total dos pacientes na comunidade (OMS, 2001, 09-10).

A OMS e a Organização Pan-Americana da Saúde - OPAS lançaram uma iniciativa para reestruturação da atenção em saúde mental na Região das Américas, visando o desenvolvimento da atenção vinculada à atenção primária em saúde e ao contexto dos sistemas de saúde locais. Isto resultou na Declaração de Caracas (1990) que propõe princípios orientadores básicos para atingir uma adequada atenção em saúde mental, não importando como e onde seja aplicada, são eles: diagnóstico, intervenção precoce, participação do usuário, parceria com a família, envolvimento da comunidade local e integração na atenção primária de saúde (OMS, 2001).

A partir desses dados, segue algumas considerações acerca da Atenção Primária em Saúde - APS.

Como dito anteriormente, na Conferência Internacional de Cuidados Primários em Saúde (1978), realizada em Alma-Ata, no Casaquistão, estabeleceu-se a doutrina da APS através das experiências desenvolvidas em diferentes partes do mundo, sendo que para sua definição foram considerados dois aspectos implícitos na expressão: estratégia e nível de atenção (VIANA; FAUSTO, 2005).

Segundo este documento a APS é:

La atención primaria de salud es la asistencia sanitaria esencial baseada en métodos y tecnologías prácticos, científicamente fundados y socialmente aceptables, puesta al alcance de todos los individuos y familias de la comunidad mediante su plena participación y a un coste que la comunidad y el país puedan soportar (...). La atención primaria forma parte integrante tanto del sistema nacional de salud, del que constituye la función central y el núcleo principal, como del dessarrollo social y económico global de la comunidad. Representa el primer nivel de contacto de los individuos, la família y la comunidad con el sistema de salud, llevando los más cerca posible la atención de salud al lugar donde residen y trabajan las personas, y constituye el primer elemento de un proceso permanente de asistencia sanitaria. (...) se orienta hacia los principales problemas sanitários de la comunidad y presta los correspondientes servicios preventivos, curativos, de rehabilitación y de fomento de la salud (OMS, 1978, p. 03-04). 
No Brasil, essa conceituação fundamentou propostas e programas na área de saúde e exerceu influências nos processos de expansão em saúde (ANDRADE; BARRETO; BEZERRA, 2007).

Elias (2005) expõe a divisão entre os níveis de atenção primário, secundário e terciário como uma forma abstrata de compreender o sistema de saúde, sendo diferenciados de acordo com o grau de incorporação de tecnologia material e de especialização de seus recursos humanos.

Paim (2003) recupera a divisão pontuando que esta forma de organização estrutura o “continente do sistema de saúde” (p.570), embora, por conduzir uma proposta regionalizada e hierárquica, descentralizando serviços mais simples e concentrando os mais complexos, encontre resistências nas tentativas de sua implantação.

Exemplificando temos: o nível primário de atenção seria o que detém caráter comunitário ou ambulatorial e compõe a atenção básica; o secundário seria composto por tecnologias intermediárias, consultórios especializados e pequenos hospitais; já o terciário seria a referência para os demais, constituído por grandes hospitais gerais e especializados, que concentram a tecnologia compatível com as subespecialidades médicas (PAIM, 2003).

Schraiber e Mendes-Gonçalves (2000) discutem a associação da atenção primária a uma assistência de baixo custo confundida com medicina 'simplista' ou de baixa qualidade, fato justificado pela origem que remete a este significado e pelas competências resolutivas de menor custo quanto ao material e às ações especializadas. Contrapondo este dado evidenciam que muitas situações diárias podem se constituir enquanto casos simples, por vezes patologicamente fáceis, mas nem por isso deixam de implicar uma complexidade assistencial.

A atenção primária, ao ser um primeiro atendimento, servirá obrigatoriamente de porta de entrada para o sistema de assistência. Ao mesmo tempo, porém, constitui, no sistema, um nível próprio de atendimento e deve ir resolvendo uma dada gama de necessidades que extrapolam a esfera da intervenção curativa individual (SCHRAIBER; MENDES-GONÇALVES, 2000, p.35-36, grifos no original). 
Desse modo, as unidades de atenção primária representam importante porta de entrada, respondendo por grande número de consultas médicas e outros procedimentos assistenciais. Atreladas ao papel assistencial estão as demandas sanitárias, como a vigilância e controle de doenças; os riscos de adoecimento e a educação em saúde (SALA; NEMES; COHEN, 1996; SCHRAIBER; MENDES-GONÇALVES, 2000).

Portanto, constitui uma forma tecnologicamente específica de atenção em saúde que integra síntese de saberes e complexa rede de ações individuais e coletivas, curativas e preventivas, assistenciais e educativas (SALA; NEMES; COHEN, 1996; SCHRAIBER; MENDES-GONÇALVES, 2000).

Em 1998, Barbara Starfield publicou em Nova York o livro Primary Care: Balancing Health Needs, Services and Technology, representando um marco para APS dada a apresentação sobre as evidências do seu impacto positivo em diversos países, além de propostas de métodos para avaliação dos resultados produzidos pelos sistemas e profissionais da atenção primária (ANDRADE; BARRETO; BEZERRA, 2007).

Starfield conceitua a APS como nível do sistema de saúde de amplo acesso para todo novo problema ou necessidade, de efeito temporal duradouro, centrado mais na pessoa do que na doença, coordenado e integrado em termos de lugares e profissionais que nele atuam. Além disso, considera que é capaz de oferecer atenção à maioria dos agravos à saúde, com exceção daqueles mais raros ou pouco habituais. Assim, a APS representa a base do sistema de saúde com um enfoque que determina o modo de atuar nos níveis restantes do sistema (STARFIELD, 2001; GOULART, 2002).

No Brasil, a APS recebeu considerável impulso a partir de 1980 com a municipalização da saúde e ao ser identificada como estratégia central para se atingir a meta global: Saúde para todos no ano 2000, lançada pela OMS (COHN; NAKAMURA; COHN, 2005). 
Foram implementados em boa parte do território nacional pelo MS o Programa de Agentes Comunitários de Saúde - PACS, a partir de 1990, e o Programa de Saúde da Família - PSF, criado em 1994, na tentativa de estender ações básicas em saúde aos segmentos da população até então sem acesso aos serviços de saúde (CARNEIRO JR; SILVEIRA, 2003; LOPES; PALMA, 2005).

O PSF, estruturado pelo Ministério da Saúde, articulou três linhas de contribuições: as proposições da Atenção Primária, definidas na Conferência de Alma-Ata, em 1978; a Medicina de Família implantada nos países desenvolvidos e em Cuba; e a Medicina Geral e Comunitária, destinada aos segmentos da população mais excluídos nos países centrais, vigente a partir dos anos 1970 (MARSIGLIA; SILVEIRA; CARNEIRO JR, 2005).

Mais recentemente, estendeu sua cobertura e seus limites, aumentando o contingente de profissionais e usuários.

Somando essas idéias, foram utilizados os descritores: 'PSF' e 'violência'; 'PSF' e ‘álcool’; 'PSF' e 'drogas’; 'PSF' e 'saúde mental’; como marcadores das relações entre um serviço de saúde de atenção primária e as demandas e necessidades médico-sociais em revisão de literatura científica nas bases de dados on line BIREME - Centro Latinoamericano e do Caribe de Informação em Ciências da Saúde; SciELO - Scientific Electronic Library Online; LILACS - Literatura Latino-Americana e do Caribe em Ciências da Saúde e MEDLINE Literatura Internacional em Ciências da Saúde.

Obteve-se um número significativo de estudos que apresenta a relação 'PSF' e ‘drogas’ (62); seguido por 'PSF’ e ‘saúde mental’ (30).

Embora existam poucos estudos relacionados aos demais descritores (menos que 08 produzidos), verifica-se que houve a expansão dos serviços de saúde na atenção primária atrelada às crescentes dificuldades em responder demandas tão heterogêneas dos diversos 
segmentos da população e em desenvolver a justiça social na busca da diminuição das desigualdades sociais (CARNEIRO JR; SILVEIRA, 2003; CARNEIRO JR et al., 2006).

Urge a organização de práticas equânimes cotidianas e singulares nos serviços de saúde, o que evidenciaria possibilidades de consolidação dos princípios do SUS, recolocando os ideários e o discurso, que se têm concentrado na macropolítica, na micropolítica do sistema de saúde brasileiro (CAMPOS, 2006; CARNEIRO JR et al., 2006).

As autoras Malfitano e Lopes (2003) ao problematizarem o momento atual do PSF diferenciam as ‘ações de saúde básica’ das ‘ações básicas de saúde’. Expõem que o Programa prevê ações de saúde básica (intervenções que oferecem assistência para problemáticas e/ou doenças relacionadas à saúde tradicional, como diabetes, hipertensão, pré-natal, etc.); entretanto não prioriza as ações básicas de saúde (intervenções relacionadas às demandas da população de um território determinado a partir de suas características sócio-culturais e econômicas visando à integração e à atenção de todos).

Todavia, com a inversão do foco centrado no indivíduo para a família e a proposta de ações próximas à comunidade e ao território, um conjunto de situações (depressão, drogadição, abuso sexual, cárcere privado, risco de suicídio, situações de violência) têm evidenciado outras demandas e necessidades de saúde ao surgirem diante dos profissionais de saúde; o que vai ao encontro da noção de ‘ações básicas de saúde’ (MALFITANO; LOPES, 2003).

Produções científicas de autores como Schraiber, Mendes-Gonçalves e Merhy, defendem a especificidade tecnológica do trabalho em saúde na atenção primária no processo de produzir saúde, pois há possibilidades efetivas e menos aprisionadas ao trabalho médico restrito para a promoção da autonomia do cuidado em saúde (CARNEIRO JR; SILVEIRA, 2003). 
Starfield (2002) destaca mundialmente a APS como importante tecnologia em saúde ao promover a interação entre a biologia e o ambiente social e físico; e, num aspecto mais próximo, ao favorecer as relações em um território determinado englobando a população da área e as diferentes instituições e equipamentos sociais presentes nesse espaço geográfico, proporcionando resultados efetivos na atenção integral à saúde (CARNEIRO JR et al., 2006).

Isto nos permite compreender que há possibilidades de organizar ações mais flexíveis, que se adaptem às especificidades dos grupos sociais que demandem cuidados individuais e coletivos nesse nível da atenção (CARNEIRO JR; SILVEIRA, 2003; CARNEIRO JR et al., 2006).

Portanto, os serviços de atenção primária são: “campos férteis para se operar práticas que visem ao enfrentamento dos desafios da incorporação da heterogeneidade, das desigualdades sociais e das diferentes necessidades de saúde” (CARNEIRO JR et al., 2006, p.33). 


\section{CAPÍTULO 3 - PERCURSO TEÓRICO}

\subsection{COMUNIDADE E TRABALHO EM SAÚDE}

\subsubsection{DELINEANDO O CONCEITO DE COMUNIDADE E SUA}

APROPRIAÇÃO NO CAMPO DA SAÚDE

No Novo Dicionário Aurélio da Língua Portuguesa, encontra-se a palavra ‘comunidade’ significando: qualidade ou estado do que é comum; comunhão; concordância, conformidade, identidade; o corpo social; a sociedade; qualquer grupo social cujos membros habitam uma região determinada tem um mesmo governo e estão irmanados por uma mesma herança cultural e histórica; qualquer conjunto populacional considerado como um todo, em virtude de aspectos geográficos, econômicos e/ou culturais comuns; grupo de pessoas considerado, dentro de uma formação social complexa, em suas características específicas e individualizantes; grupo de pessoas que comungam uma mesma crença ou ideal; agrupamento que se caracteriza por forte coesão baseada no consenso espontâneo dos indivíduos; dentre outros (FERREIRA, 2004).

O termo sofre uma polissemia pela existência das múltiplas óticas que faz com que não seja possível demarcar, sem exigência de princípios, uma idéia clara e compartilhável sobre si (CASTIEL, 2004).

Apesar desses múltiplos sentidos, que são dependentes do referencial de quem os emprega e do contexto em que é utilizado; 'comunidade' parece ainda estar associada às idéias caracterizadas pelos laços sangüíneos, pelo entendimento comum, pelas tradições de um povo, tribo e/ou família, enfim, um grupo de pessoas, geograficamente delimitados, que compartilham interesses em comum sem que estes precisem ser explicitados ou discutidos para se chegar a um consenso (SILVA; SIMON, 2005).

Um dos teóricos das ciências sociais que trabalhou o conceito de ‘comunidade’ foi o sociólogo alemão Ferdinand Tönnies, que publicou em 1885: Gemeinschaft und Gesellschaft (Comunidade e Sociedade). Neste trabalho, o autor diferencia comunidade de sociedade em 
termos das delimitações geográficas, rural e urbano, bem como, em termos de princípios, coletivos e individualistas (CASTIEL, 2004; SILVA; SIMON, 2005).

Logo, Tönnies traz a concepção de ‘comunidade’ como:

um tipo ideal, uma propriedade característica das organizações onde predominava um espírito de comunhão ou comunalidade. Isto ocorreria com mais freqüência em contextos sociais-rurais, em pequenos povoamentos onde as relações se regeriam por vários traços distintivos da 'Gesellschaft' ou 'sociedade'-, modo de relação social próprio do individualismo capitalista (CASTIEL, 2004, p.619).

Diante disso, tem-se a idéia de comunalidade demarcada como a que está ligada a alguma localidade geográfica, com altos teores de homogeneidade, compartilhar interesses, afinidades, trocas simbólicas, laços relacionais solidários (CASTIEL, 2004).

Muitos debates e críticas ocorreram diante das idéias da 'comunidade tonniesiana', com acusações de nazismo ou de comunismo. Não obstante esses extremismos, inferências sobre a conceituação de comunidade e desdobramentos segundo esta ótica permanecem em um fértil debate até os dias atuais (CASTIEL 2004).

Entretanto, artigo de Silva e Simon (2005) problematiza a continuidade dessa mesma concepção, utilizada de forma a-crítica, atemporal e a-histórica. Por mais que o uso de ‘comunidade’ tenha sido ampliado, esta expansão não foi acompanhada da reflexão crítica e da necessária contextualização em seus aspectos sociais, econômicos, culturais e políticos.

O que podemos apreender com isso é que o conceito de comunidade parece imune às transformações sociais, econômicas, culturais, políticas; aos avanços tecnológicos, às reconfigurações de tempo e espaço (SILVA; SIMON, 2005, p. 40).

Neste sentido, as autoras fazem um paralelo aos dias atuais revelando preocupação quanto ao emprego do termo por profissionais de saúde no cotidiano de práticas sem a reflexão sobre o que ele representa (SILVA; SIMON, 2005).

Apontam que isso ocorre devido às concepções dos profissionais, os quais partem do pressuposto de que é um termo consensual e que gera compartilhamento dos mesmos significados e sentidos quando utilizado. Entretanto, relatos de trabalhos que empregam os 
termos comunidade e participação comunitária evidenciam a diversidade dos significados (SILVA; SIMON, 2005).

Outro ponto a se considerar, é que o termo comunidade também pode ser muito utilizado talvez porque remete a algo que parece bom em si, que compreende boas intenções dos profissionais que se dispõem a trabalhar com o tema; sendo assim associado a profissionais preocupados com questões de relevância social. Isto dá a falsa impressão de que um trabalho é bom, relevante socialmente, simplesmente por indicar como intenção o atingir à comunidade (SILVA; SIMON, 2005).

Por um lado, muitos dos trabalhos, que se referem à comunidade, podem apenas expressar ‘saudosismo ingênuo’, enfocando valores considerados ‘naturais’ a ela, como:

a solidariedade, a cooperação, o compartilhamento de necessidades e interesses, a justiça social, o fortalecimento das pessoas em relação ao seu poder de decisão e de influenciar a tomada de decisões, a consciência crítica, e a mudança social emancipatória, a possibilidade de construção de concretização de projetos individuais através dos projetos coletivos (SILVA; SIMON, 2005, p. 42).

Por outro, os demais empregam o termo sem nenhum comprometimento com autoidentificação de seus componentes (SILVA; SIMON, 2005).

Sobre isto, Castiel (2004) discute que um dos conceitos da promoção de saúde é ‘comunidade’ e é relevante o fato de, neste caso, tal noção envolver definições prescritivas:

Ao condicionar como deve ser uma comunidade, distintos profissionais de saúde passam a estabelecer determinados rumos em suas práticas de saúde (campanhas, portarias, projetos, manuais, cursos e outros) sem atentar para as eventuais insuficiências do conceito empregado (p. 618-619).

E embora os resultados das ações sanitárias sejam de baixa resolutividade, em uma avaliação sobre o processo não costuma ser usual a preocupação com a pertinência das categorias e teorias utilizadas (CASTIEL, 2004).

Diante disso, a necessidade de problematizar e refletir, portanto, se colocam para que a promulgação do sentido do conceito venha auxiliar e não comprometer práticas de saúde. 
Na saúde, observa-se ‘comunidade’ enquanto uma categoria onipresente nos terrenos da promoção, prevenção e da pesquisa das relações entre aspectos sócio-culturais e a saúde. Na saúde pública, a idéia está em uso principalmente desde a década de 60, época de diversas propostas de ensino e pesquisa que resultaram nos departamentos da área que receberam, por exemplo, designações de 'medicina comunitária’ (CASTIEL, 2004).

Retomando o documento da Conferência de Alma-Ata, em sua declaração final em 1978, percebe-se mudanças significativas na história da saúde pública ao ser lançada a proposta dos ‘cuidados primários em saúde’, que são definidos por:

cuidados essenciais em saúde, baseados em métodos e tecnologias práticos, cientificamente bem fundamentados e socialmente aceitáveis, colocados ao alcance universal dos indivíduos, famílias e comunidade, mediante plena participação destes (...). Fazem parte integrante tanto do sistema de saúde do país, do qual constituem a função central e o foco principal, quanto do processo de desenvolvimento social e econômico da comunidade. Representam o primeiro nível de contato das pessoas, da família e da comunidade com o sistema nacional de saúde, através do qual os cuidados de saúde são levados o mais próximo possível dos lugares em que as pessoas vivem e trabalham. Constituem o primeiro elemento de um continuado processo de assistência à saúde (SCLIAR, 2006, p.01, grifos nossos).

E, ao destacar a palavra comunidade por três vezes, reconheceu a distinção entre a atenção primária prestada a indivíduos ou famílias e a atenção prestada à comunidade (STARFIELD, 2002).

Como visto anteriormente, no Brasil, a instalação de serviços de saúde na atenção primária assume um papel central nas Políticas Públicas a partir de 1980, fato decorrente das reformas institucionais após o Movimento Sanitário ${ }^{11}$ e das proposições do Sistema Único de Saúde - SUS, criado e regulamentado pela Constituição de 1988.

O SUS é orientado pelos princípios de universalidade do acesso, eqüidade, integralidade da atenção, descentralização da gestão, regionalização e hierarquização da rede, e participação da comunidade. E mantém:

\footnotetext{
${ }^{11}$ Nos anos 80, este movimento ganhou força política questionando duramente o sistema de saúde durante a conjuntura de redemocratização do Estado brasileiro o que resultou na chamada Reforma Sanitária. Esta reforma propugnava alterações no formato institucional e jurídico do sistema de saúde de modo a propiciar a universalização da atenção à saúde, gratuita e sob controle do Estado (NEMES, 2000).
} 
o ideário do resgate da cidadania, reconhecendo que, para alcançar seus objetivos, é necessário implementar políticas e correspondentes programas que contemplem as várias dimensões envolvidas no processo saúde-doença: habitação, transporte, alimentação, trabalho, lazer, entre outros (CARNEIRO JR; SILVEIRA, 2003, p.1828).

O último princípio, participação da comunidade, diz respeito à relação do Estado/sociedade denominado convencionalmente, na área de Saúde Coletiva, de controle social (ELIAS; COHN, 1995).

Entretanto, pode ser entendido também como a participação comunitária prevista pelo conceito de co-responsabilidade; uma participação na construção da saúde e/ou de estratégias em um local determinado junto aos profissionais de saúde para obter uma melhor qualidade de vida.

\subsubsection{TRABALHO EM SAÚDE E COMUNIDADE NO CONTEXTO DO PSF}

A partir de 1990, o MS, seguindo a meta global Saúde para Todos no Ano 2000 da OMS, identificou e fortaleceu como foco central para sua atuação a atenção primária do sistema de saúde. E, implantou dois programas segundo os princípios e diretrizes do SUS: o Programa de Agentes Comunitários de Saúde - PACS e o Programa de Saúde da Família PSF, já citados anteriormente (COHN; NAKAMURA; COHN, 2005).

O PACS introduziu o enfoque na família como unidade de ação programática, não apenas centrando no indivíduo; a noção de área de cobertura por família e a visão ativa da intervenção em saúde, ou seja, não 'esperar’ a demanda para intervir e sim atuar preventivamente como um instrumento real de organização da demanda. Além disso, trouxe um aspecto diferencial para o atendimento à saúde até então vigente, a concepção de integração com a comunidade e de uma visão menos reducionista sobre a saúde, não se detendo apenas na intervenção médica (VIANA; DAL POZ, 1998; SANTOS, 2006).

Uma década depois, objetivando reorganizar as Unidades Básicas de Saúde, tornandoas resolutivas e habilitadas para a construção de vínculos entre profissionais de saúde e população numa prática de saúde integral e participativa, o PSF tornou-se a principal 
estratégia de governo para reorganizar a assistência à saúde no país (COHN; NAKAMURA; COHN, 2005; VILLELA; MONTEIRO, 2005).

Assim, a lógica para viabilizar este intuito, o de reverter o modelo assistencial, consistiu na mudança do objeto de atuação e da organização geral dos serviços tomando-se novas bases e critérios. Sobre isto temos a afirmação:

Essa [nova] perspectiva faz com que a família passe a ser o objeto precípuo de atenção, entendida a partir do ambiente onde vive. Mais que uma delimitação geográfica, é nesse espaço que se constroem as relações intra e extrafamiliares e onde se desenvolve a luta pela melhoria das condições de vida - permitindo, ainda, uma compreensão ampliada do processo saúde/doença e, portanto, da necessidade de intervenções de maior impacto e significação social (MINISTÉRIO DA SAÚDE, 1997, p.08).

Logo, percebe-se que a interação entre a comunidade, aqui pensada como os moradores da área de cobertura, e os trabalhadores de saúde é marcada como categoria relevante para o fortalecimento das práticas desenvolvidas pelo PSF. Isto também pode ser observado quando se ressalta o aspecto inovador da inclusão do agente comunitário de saúde (ACS) na equipe ${ }^{12}$, o que favorece a democratização do saber (técnico e popular) na relação produzida entre profissionais de nível superior e moradores da área.

Crevelim e Peduzzi (2005) corroboram essa idéia e destacam algumas características do PSF que parecem favorecer a integração entre a comunidade e as equipes de saúde da família (ESF). São elas: a introdução dos ACS nas ESF, a adscrição de uma clientela em um território definido, a atuação embasada na ótica da Vigilância em Saúde e o trabalho em equipe multiprofissional.

Algumas diretrizes norteadoras do PSF, como o trabalho em equipe e a participação da comunidade/controle social se aproximam à medida que decorrem e expressam as relações

\footnotetext{
12 O PSF tem grandes semelhanças com as propostas do PACS, mas inova na estruturação da Equipe de Saúde da Família (ESF) composta por médico generalista, enfermeiro, auxiliar de enfermagem e quatro a seis agentes comunitários de saúde (número variável de acordo com o número de pessoas sob responsabilidade da equipe na área de abrangência).
} 
entre a população e o serviço de saúde, assim como, em um plano ainda mais microscópico, as relações entre trabalhadores e seus usuários (CREVELIM; PEDUZZI, 2005).

Starfield (2002) para avaliar sistemas e programas em atenção primária, ressalta três tipos de características gerais: $1^{\circ}$ ) os aspectos exclusivos da atenção primária; $2^{\circ}$ ) os aspectos derivativos; e $3^{\circ}$ ) os aspectos fundamentais, mas não exclusivos. Aqui, dialogamos com os ‘aspectos derivativos’ (resultantes do alto nível de alcance das qualidades exclusivas e fundamentais da atenção primária): a centralização na família, a competência cultural e a orientação para a comunidade.

A ‘orientação para a comunidade’ evidencia um alto grau de integralidade da atenção geral em saúde e é definida pela: “capacidade da atenção primária em reconhecer e responder às necessidades da comunidade e promover ações intersetoriais nas ações comunitárias” (ELIAS et al., 2006, p.635).

Entretanto, diferentes formas de definições são utilizadas, mas respeitam a idéia comum de que é: “uma abordagem [...] que utiliza habilidades epidemiológicas e clínicas de forma complementar para ajustar os programas para que atendam às necessidades específicas de saúde de uma população definida” (STARFIELD, 2002, p.537).

Sua avaliação requer três tipos de informações: o conhecimento das necessidades de saúde da comunidade, o quanto os profissionais se envolvem nos assuntos da comunidade (como exemplo, o conhecimento a respeito das redes sociais e dos sistemas de apoio disponíveis, incluindo recursos recreacionais, religiosos, etc.); e o quanto os profissionais envolvem a comunidade em questões relacionadas à prática cotidiana (STARFIELD, 2002).

O ápice de uma atenção orientada para a comunidade é a possibilidade de garantir que os recursos fluam para áreas em que são mais necessários; diminuindo, assim, as iniqüidades dentro das populações. Desse modo, a atenção primária, através de sua orientação para a comunidade, passa a dividir a responsabilidade com a saúde pública objetivando maximizar a 
extensão, na qual os serviços de saúde possam superar as desvantagens sociais e seus efeitos adversos sobre a saúde (STARFIELD, 2002).

Neste sentido, outra questão que se coloca, considerando a dimensão comunicacional, é a compreensão acerca da interação profissional de saúde e comunidade, vice-versa.

Ayres (2001) discute a concepção do lugar do ‘sujeito’ nas práticas de saúde da atualidade e defende o caráter relacional, pragmático e reconstrutivo das identidades subjetivas nas práticas do setor. Também pontua a necessidade de transformações das práticas de saúde, com base em 'giros’ teórico-filosóficos, relacionados entre si:

a) secundarização da idéia de sujeito em favor da idéia de contextos de intersubjetividade, na construção de categorias para o conhecimento e intervenção; b) subsunção do interesse pelo controle técnico das doenças na idéia mais abrangente de sucesso prático de projetos de felicidade humana, na definição das finalidades da intervenção; c) transformação do cuidado, na atitude orientadora do conjunto das ações voltadas para a saúde das pessoas (AYRES, 2001, p.63).

O autor conclui que um dos maiores desafios é superar as ‘barreiras lingüísticas’ que a técnica interpõe a uma autêntica interação entre profissionais e população/comunidade defendendo pontes lingüísticas para ocasionar o compartilhamento de horizontes entre os técnicos e o público já que "se trata de prescrever comportamentos, formas de vida, intervenções sobre o corpo ou a mente das pessoas” (AYRES, 2001, p.70).

Ressalta a importância do resgate da dignidade de outros tipos de sabedoria na construção das verdades úteis para a construção da saúde, desde os conhecimentos acadêmicos, como a filosofia, o direito e certos ramos das ciências humanas, até as diversas sabedorias práticas transmitidas secularmente nas diversas tradições culturais (AYRES, 2001).

Em revisão de literatura científica nas bases de dados on line BIREME - Centro Latinoamericano e do Caribe de Informação em Ciências da Saúde; SciELO - Scientific Electronic Library Online; LILACS - Literatura Latino-Americana e do Caribe em Ciências da Saúde e MEDLINE - Literatura Internacional em Ciências da Saúde, a partir dos 
descritores: ‘comunidade' e 'PSF', verificou-se a produção de 74 trabalhos, entre artigos, livros, dissertações e teses.

A maioria dos estudos enfoca a prática de profissionais de saúde (exceto o ACS) no PSF evidenciando a importância da sua atuação na comunidade; a implementação e avaliação de programas (saúde da criança, saúde bucal, controle de dengue, dentre outros) realizados conjuntamente com o PSF; e a avaliação de serviços de saúde sob a estratégia do PSF, bem como a utilização de métodos de coleta de dados e discussões sobre as políticas de saúde vigentes.

Há 07 estudos que utilizam uma determinada comunidade enquanto objeto de intervenção em saúde; 05 estudos que relacionam a participação da comunidade com a incorporação e o trabalho do ACS e 05 com a execução do controle social.

Foram separados 07 estudos ${ }^{13}$ que têm proximidade com a proposta do presente estudo, ou seja, associando comunidade e PSF para verificação da incorporação (ou não) de demandas e necessidades médico-sociais. Entretanto, nestes estudos o foco prioritário é a constituição do vínculo entre usuário e serviço de saúde.

Observam-se lacunas de conhecimento sobre representações de comunidade no contexto de um serviço de saúde sob a lógica do PSF, assim como lacunas sobre a participação comunitária, no seu sentido mais amplo, favorecendo ou não a incorporação de demandas e necessidades médico-sociais. Embora muitos estudos citem (somente) o alto risco social e sanitário, a violência, a marginalização, como características marcantes da comunidade, na qual o PSF intervém.

Entende-se que a existência de lacunas obtidas na revisão de literatura resulta, principalmente, da priorização das 'necessidades de saúde' reduzidas aos processos

\footnotetext{
${ }^{13}$ Os demais estudos foram excluídos por não apresentarem relação com os descritores supracitados.
} 
fisiopatológicos nas concepções dos serviços de saúde (protocolos padronizados) em detrimento das questões sociais (demandas e necessidades da comunidade).

Sabe-se que alguns estudos marcam a importância da proximidade com a comunidade enquanto 'aliada’ para o desenvolvimento do trabalho em saúde e reconhecem a inabilidade dos profissionais no manejo de demandas e necessidades médico-sociais pela desinformação e pouca utilização dos recursos da própria comunidade; porém, não é verificado um aprofundamento desta discussão.

\subsection{DEMANDAS E NECESSIDADES MÉDICO-SOCIAIS}

\subsubsection{A CONSTRUÇÃO HISTÓRICA DO CONCEITO E SUA UTILIZAÇÃO}

\section{NO CAMPO DA SAÚDE COLETIVA}

É relevante para este estudo observar autores e pesquisadores que estudam o conceito de ‘necessidades de saúde’ na atenção primária desde o final da década de 80 do século XX para aplicá-los enquanto referencial de investigação sobre as representações de comunidade e como estas são produzidas em determinado contexto.

Deste modo, partimos da explicação do conceito de 'necessidades de saúde’ proposto por Schraiber e Mendes-Gonçalves (2000):

Ao pensar em necessidades de saúde imediatamente nos lembramos de "assistência”, pois a imagem mais clara delas está representada pela procura de cuidados médicos que um doente faz ao dirigir-se a um serviço assistencial. Caracterizamos essa procura como demanda, uma busca ativa por intervenção que representa também consumo, no caso de serviços. A origem dessa busca é o carecimento, algo que o indivíduo entende que deve ser corrigido em seu atual estado sócio-vital. (...) Esse indivíduo (...) enxerga a saída: assume que há correção desejável para seu problema e que existem meios para isso. $\mathrm{O}$ resultado das intervenções sobre qualquer desses carecimentos é reconhecido, portanto, como necessidade, tornando as próprias intervenções também necessidades (p.29, grifos no original).

Estes autores explicam que:

o modo de organizar socialmente ações em saúde para a produção e distribuição efetiva dos serviços será não apenas resposta a necessidades, mas, imediatamente, contexto instaurador de necessidades (SCHRAIBER; MENDES-GONÇALVES, 2000, p.30). 
No PSF há um acolhimento universal: por trazer a problematização da resolutividade em questão, pretender trabalhar de modo intersetorial e pela característica de ser um “contexto instaurador de necessidades” (BATISTA, 2005, p.121). Este serviço de saúde, assim, detém necessidades que muitos técnicos não dominam:

trata-se de carecimentos pertencentes à vida cotidiana que, por meio de crítica à ciência tradicional e suas técnicas, relacionamos ao adoecer humano e à recuperação, mas que ainda não são considerados deste modo pela ciência tradicional e por isso não estarão já incluídos na produção usual dos serviços e nas ações técnicas conhecidas. Não queremos indicar com isso que a organização dos serviços definirá as necessidades por sobre a vida social, o que terminaria no mesmo caminho da unilaterialidade ética e política de proposições, anteriormente criticado. Antes, (...) busca sugerir alternativas por meio do resgate de valores que foram negativados ao longo das opções históricas que elegeram a forma atual dominante de construção da vida social, trabalhando no sentido da abertura à instauração de novos sistemas de valores (SCHRAIBER; MENDES-GONÇALVES, 2000, p.33, grifos no original).

Entretanto, ainda são incipientes os estudos que trazem uma aproximação teórica entre as necessidades de saúde em atenção primária e as demandas e necessidades no contexto de práticas sob a lógica do PSF (modelo em curso).

Segundo Somarriba (2001):

[a] consciência crescente das estreitas relações entre saúde e condições econômicas, sociais e culturais tem forçado a medicina a mudar seu foco da doença para a saúde, do tratamento para a prevenção, levando-a a propor o deslocamento das respostas organizacionais às doenças do hospital para a comunidade; a localizar os centros de saúde junto dos locais de moradia; a formular modelos de atendimento integral (como é o caso dos programas de Saúde da Família [...]); a propor medidas voltadas para a alteração do meio ambiente e das oportunidades e estilos de vida considerados insalubres (p.334).

A medicina, conforme citada pela autora, ao adotar uma visão mais abrangente dos determinantes das doenças passa a reconhecer as contribuições relevantes ao campo da saúde por outras áreas de conhecimento. Isto tem gerado a necessidade de enfoque interdisciplinar e/ou transdisciplinar aos problemas de saúde favorecendo a composição de equipes multidisciplinares de saúde desde no espaço hospitalar como nas unidades de cuidados primários (SOMARRIBA, 2001). 
A Saúde Coletiva é caracterizada por um campo amplo de práticas e possui recente constituição (menos de quatro décadas); embora, possua uma história bem mais antiga quando se considera a sua institucionalização em cursos, congressos e produção científica marcados por pressupostos desde quando se iniciou um pensar sobre a saúde, transcendendo a questão da doença em si mesma (NUNES, 2007).

Perpassando os movimentos preventivistas $^{14}$ e de medicina social ${ }^{15}$, os quais culminaram em revisões sobre as questões da prevenção e do acercamento de uma dimensão ampliada das próprias políticas de saúde em direção à promoção da saúde, a Saúde Coletiva engloba uma contribuição teórica de diferentes campos disciplinares visando ao: “entendimento das questões e problemas das coletividades expostas a riscos e agravos” (NUNES, 2007, p.32).

Assim, utilizando o exemplo de Nunes (2007), este campo pode ser comparado à imagem de um mosaico. Ou seja,

conjunto formado por partes separadas, mas que se aproximam quando a compreensão dos problemas ou a proposta de práticas se situam além dos limites de cada 'campo disciplinar', exigindo arranjos interdisciplinares. [...], entendemos que o campo não é simplesmente um território opaco, um contraditório de conhecimentos, saberes e práticas, desarticulados, mas se compõem de acordo com as necessidades em descrever, explicar e/ou interpretar a realidade de saúde que se deseja estudar, avaliar ou transformar. Para isso, os conceitos, as categorias analíticas, as chaves interpretativas, procedentes do núcleo duro das ciências - o corpus teórico - lançam suas luzes para o entendimento dos objetos e sujeitos investigados pelos pesquisadores. Agora, o mosaico se transforma em um vitral, no qual os problemas estão filtrados pela teoria (p.29).

\footnotetext{
${ }^{14}$ Designado também por 'projeto preventivista', foi amplamente discutido com o apoio da Organização PanAmericana de Saúde na segunda metade dos anos 50 do século XX. Associa-se à crítica quanto ao modelo biomédico vinculado ao projeto pedagógico possibilitando a criação dos departamentos de medicina preventiva e social nas escolas médicas e de disciplinas como: epidemiologia, ciências das condutas, bioestatística e administração dos serviços. Preocupou-se com a perspectiva biopsicossocial do indivíduo e a extensão da atuação pedagógica ao criar trabalhos comunitários (NUNES, 2007).

15 A 'medicina social' compreende duas fases: a importante construção teórico-conceitual (1974-1979), com realizações de pesquisas sociais, epidemiológicas sobre determinantes econômicos da doença e do sistema de saúde associada à discussão de propostas alternativas ao sistema vigente. E a fase seguinte (1980-1986), denominada 'político-ideológica', onde ocorreu a disseminação da proposta de reforma e eventos como a VII Conferência Nacional de Saúde (1979) e a VIII Conferência Nacional de Saúde (1986), marcantes para o processo de reforma da saúde pública brasileira (NUNES, 2007).
} 
A interface da Saúde Coletiva e Ciências Sociais vêm permitindo uma maior flexibilidade para introdução de 'novos’ objetos, tais como: construção social da saúde e da doença; gênero e sexualidade; desinstitucionalização da loucura; violência; dimensão social dos perfis de morbimortalidade; com ênfase nos processos não biológicos das enfermidades/sofrimentos; nas articulações simbólicas na construção das identidades sociais; nas questões das práticas (em dissonância ou consonância) com normas e prescrições de comportamentos; e, nas relações entre o saber médico e os demais campos da vida social.

O conceito de ‘temas médico-sociais’ é descrito por Kiss (2004) em sua dissertação de mestrado a partir de um resgate histórico sobre a noção de Medicina Social, baseada em García (1985) ${ }^{16}$, que a compreende como uma das áreas de produção de conhecimento em Saúde Coletiva; integrante de um campo de conhecimento interdisciplinar que se ocupa com os aspectos sociais relacionados ao processo saúde-doença e aos serviços de saúde.

O termo 'Medicina Social’ é inicialmente proposto por Guèrin em 1838 designando genericamente o modo de tomar coletivamente a questão da saúde e inspira, de forma geral, o objeto de estudo do campo. Enfoca o processo saúde-doença na coletividade, estuda a política e a organização dos serviços de saúde institucionalizados, além das concepções e práticas populares em saúde (ALMEIDA FILHO, 2003; KISS, 2004).

Diante disso, o conceito de ‘objetos médico-sociais’, que anteriormente serviu à Saúde Coletiva para postular a integração médico-sanitária, destaca-se por ser mais conexo ao desenvolvimento da saúde do que respostas às doenças (SCHRAIBER; D’OLIVEIRA; COUTO, 2006).

A Saúde Coletiva, portanto, reúne em suas disciplinas básicas além da Medicina Social, a Epidemiologia e o Planejamento/Administração em Saúde; integra o tradicional debate entre as ciências da natureza (e sua forma de objetivação do evento em estudo) e as

\footnotetext{
16 Cf. García JC. Juan César García entrevista Juan César García. In: Nunes ED, García JC, organizadores. As ciências sociais em saúde na América Latina: tendências e perspectivas. Brasília (DF): OPAS; 1985.
} 
ciências do humano e do social; e se constitui em campo de conhecimento interdisciplinar difundindo temas tanto médico-sanitários quanto sociais (KISS, 2004; SCHRAIBER; D’OLIVEIRA; COUTO, 2006).

Nessa síntese, nasce o conceito de ‘temas médico-sociais’; designação em que se pode reconhecer a violência, o uso abusivo de álcool e drogas, os exercícios da sexualidade, a saúde mental, dentre outros temas (KISS, 2004; SCHRAIBER; D’OLIVEIRA; COUTO, 2006).

Adotando as considerações apresentadas, emprega-se neste estudo a idéia de demandas e necessidades médico-sociais da comunidade a partir das temáticas: violência, uso abusivo de álcool e drogas, e, sofrimento mental.

Sinteticamente, justifica-se investigar as representações de comunidade a partir das perspectivas dos profissionais de saúde de uma equipe multiprofissional de PSF devido às experiências práticas que desvelam o aumento de situações que são geradoras de demandas e necessidades médico-sociais nos serviços de atenção primária à saúde.

Dadas as lacunas sobre o tema proposto, considera-se indispensáveis discussões sobre as interações/interfaces entre as necessidades de saúde e necessidades sociais no setor Saúde para produção de qualidade de vida, integração social e direitos humanos.

Como dito anteriormente, o que nos desafia e instiga são questões acerca de como os profissionais de saúde do PSF atuam, enfrentam e se relacionam cotidianamente com uma série de demandas e necessidades de saúde e sociais que acabam originando 'novas' demandas para além das tradicionalmente acolhidas pelos serviços de saúde. E se há uma superação das dificuldades e limites expostos por esses profissionais, superação essa que deverá transitar das ‘ações de saúde básica’ para a priorização das ‘ações básicas de saúde’, fortalecendo a proposta da Atenção Primária. 
Assim, compreender e apreender as representações de comunidade dos profissionais de saúde baseando-se em demandas e necessidades médico-sociais possibilita poder pensar estrategicamente na aproximação destes profissionais com seus limites e potencialidades; fortalecendo o que poderão contribuir e realizar nas interfaces: saúde e social, em prol da 'comunidade' tratada como alvo de suas intervenções. Além de colaborarem no encaminhamento de situações que envolvam ou não a saúde e que ultrapassam para problemáticas sociais favorecendo a diminuição das 'violências', vulnerabilidades e desigualdades sociais. 


\section{CAPÍTULO 4-OBJETIVOS}

\section{Objetivo Geral}

Investigar as representações de comunidade para o trabalho em saúde tal como a tomam os profissionais do Programa de Saúde da Família (PSF) tendo por base demandas e necessidades médico-sociais em um serviço de atenção primária à saúde no município de São Paulo.

\section{Objetivos Específicos}

1. Compreender como se processa (ou não) a incorporação de demandas e necessidades médico-sociais da comunidade no trabalho da equipe multiprofissional do PSF a partir das temáticas: violência, uso abusivo de álcool e drogas, e, sofrimento mental;

2. Identificar as potencialidades da relação 'serviço-comunidade' frente às demandas e necessidades médico-sociais. 


\section{CAPÍTULO 5 - METODOLOGIA E ASPECTOS ÉTICOS}

\subsection{DELINEAMENTO DA PESQUISA}

Diante do problema de pesquisa colocado e dos objetivos estabelecidos, o percurso metodológico escolhido é o da pesquisa qualitativa, especificamente na modalidade de Estudo de Caso.

O 'estudo de caso’ é uma modalidade de pesquisa que realiza um duplo movimento: (a) compreender, da forma mais abrangente possível, o grupo ou a organização sob estudo, analisando, de maneira a mais detalhada possível, suas singularidades, a forma de interação e a lógica institucional, ideológica ou cultural que ancora suas ações e como se correlacionam com o contexto social mais amplo, e (b) “desenvolver declarações teóricas mais gerais sobre regularidades do processo e estrutura sociais” (BECKER, 1993, p.118).

Logo, o estudo de um caso não se presta, em si, à direta generalização dos resultados. Sua maior contribuição é explorar situações e tendências, debatendo, à luz das respostas criativas e singulares dos casos escolhidos, quais são suas contribuições frente a um modelo geral de atendimento ou a um contexto social (DESLANDES; GOMES, 2004).

A abordagem qualitativa proporciona a investigação do contexto mais amplo onde se inserem os atores sociais e como estes se relacionam frente ao objeto em questão: as potencialidades da relação ‘serviço-comunidade’ e a incorporação de temas médico-sociais no trabalho em saúde a partir da lógica do PSF.

\section{SÍTIO DA PESQUISA}

Em São Paulo, desde 2001, a Secretaria Municipal de Saúde (SMS) assumiu o comando da rede de atenção primária; sendo estruturada administrativamente em cinco Coordenadorias Regionais de Saúde (Leste, Sudeste, Centro-Oeste, Sul e Norte), às quais estão vinculadas 384 unidades de saúde, sendo 173 (45\%) com PSF (ELIAS et al., 2006). 
A implantação do PSF priorizou regiões consideradas 'bolsões de pobreza'17, nas quais a renda familiar era de até 05 salários mínimos. A forma operacional utilizada baseavase na parceria da SMS com instituições privadas não lucrativas, com tradição de atuação na área de saúde no município (ELIAS et al., 2006).

Neste estudo, a investigação se processa no âmbito da atenção primária em saúde, em um serviço do sistema público na proposta organizacional do PSF, o qual pertence à Supervisão de Área Técnica Vila Prudente/ Sapopemba da Coordenadoria Regional de Saúde Sudeste da SMS de São Paulo.

A região Vila Prudente/ Sapopemba conta aproximadamente com uma população de 520.000 habitantes, sendo Sapopemba a que apresenta um dos perfis epidemiológicos mais vulneráveis do município (SANTOS et al., 2004).

Em conseqüência da luta pela sobrevivência de migrantes, principalmente do Nordeste, nas décadas de 60 e 70 do século XX, Sapopemba compreende várias ocupações. Há forte organização popular na luta por direitos, com a população organizada através de associações de bairros, grupos religiosos, predominantemente grupos pastorais ligados ao catolicismo (SANTOS et al., 2004).

Neste sentido, é enfocada uma Unidade de Saúde da Família (USF) composta por 02 equipes de saúde da família (ESF), localizada nesta região com implantação superior há 05 anos e definida como 'bolsão de pobreza’. A área de abrangência é marcada por favela, risco iminente de deslizamentos, desemprego, violência, tráfico de drogas e alta taxa de homicídios.

\footnotetext{
${ }^{17}$ O conceito 'bolsão de pobreza' foi obtido, principalmente, a partir do Mapa de Exclusão Social e dos Índices de Exclusão/Inclusão Social (IEX); construídos por pesquisadores coordenados por Aldaíza de Oliveira Spozati (IZIQUE, 2003; LOPES; PALMA, 2005).
} 
A implantação do PSF ocorreu de modo diferenciado na Coordenadoria Regional Sudeste, é importante ressaltar que esta USF integrou um projeto-piloto vinculado às esferas estadual e federal, em parceria com a Fundação Zerbini, o Programa QUALIS/PSF ${ }^{18}$.

Este Programa previu além da equipe nuclear do PSF (médico generalista, enfermeiro, auxiliar de enfermagem e quatro a seis agentes comunitários de saúde), equipes ampliadas de: saúde mental (psicólogo, terapeuta ocupacional e médico psiquiatra); saúde bucal (cirurgiãodentista, atendente de consultório dentário e técnico de higiene dentária); e saúde da pessoa portadora de deficiência (fisioterapeuta, terapeuta ocupacional e fonoaudiólogo).

Sabe-se, atualmente, que as Equipes de Saúde Bucal, Saúde Mental e de Reabilitação (Equipe de Saúde da Pessoa Portadora de Deficiência) permaneceram atuando nessa região após a municipalização em 2001 (LOPES; PALMA, 2005).

\section{PROCEDIMENTOS METODOLÓGICOS}

Como técnicas de produção de dados empíricos, foram utilizadas: a entrevista em profundidade, na modalidade de entrevista semi-estruturada; e grupo focal.

Como dito anteriormente, a Unidade de Saúde da Família - USF possui 02 Equipes de Saúde da Família, que se relacionam com as ‘equipes ampliadas’: Equipe de Saúde Bucal; Equipe de Saúde Mental e Equipe de Reabilitação.

Desse modo, previu-se que todos os profissionais de nível superior da ESF em sua estrutura nuclear e 'ampliada' fossem entrevistados, a saber: médico generalista (02), enfermeiro (02), cirurgião-dentista (02), psicólogo ou terapeuta ocupacional (01), médico psiquiatra (01) e fisioterapeuta, terapeuta ocupacional e/ou fonoaudiólogo (02).

Para melhor visualização, temos:

- Equipe nuclear: médico generalista (02) e enfermeiro (02);

- Equipe ampliada:

\footnotetext{
${ }^{18}$ Ver notas anteriores ( $n^{\circ} 3$ e 10$)$.
} 
o Saúde Bucal - cirurgião-dentista (02);

o Saúde Mental - psicólogo ou terapeuta ocupacional (01) e médico psiquiatra (01);

o Reabilitação (Equipe de Saúde da Pessoa Portadora de Deficiência) fisioterapeuta, terapeuta ocupacional e/ou fonoaudiólogo (02).

Também se planejou a realização de 02 grupos focais com os demais componentes das equipes nuclear e ampliada: 1). Grupo focal com agentes comunitários de saúde (cerca de 12 participantes); 2). Grupo focal com profissionais de nível técnico: auxiliares de enfermagem, auxiliar de consultório dentário e técnico de higiene dentária (cerca de 06 participantes).

Neste sentido, previa-se a participação de aproximadamente 28 profissionais de saúde que compõem a equipe multiprofissional da USF selecionada.

\subsection{CONTEXTO DO ESTUDO E QUESTÕES OPERACIONAIS}

Em um primeiro momento foram realizadas visitas à USF para apresentação do projeto de pesquisa e agenciamentos das entrevistas e grupos focais.

A direção administrativa e alguns profissionais fizeram convites para participar das reuniões semanais de ESF, tidas como estruturantes do trabalho e que duram aproximadamente 3 horas.

Com o objetivo de conhecer e aproximar do cotidiano de trabalho, participei de 06 reuniões, sendo 03 com cada ESF. Estas reuniões se mostraram interessantes pela riqueza de informações trazidas pelos ACS quanto à sua relação com a comunidade.

Observei nos relatos de casos/situações emergentes discutidos nessas reuniões a grande proximidade dos ACS com a comunidade, entretanto com discursos enquanto profissionais a serviço da comunidade e não como integrantes dela. 
Foi difícil perceber a fragmentação da saúde em processos físicos, psicológicos e até mesmo sociais pelos ACS. Parece que esta tarefa cabe sempre aos profissionais de nível superior.

Nos contatos com o serviço pude observar grande fluxo de usuários, tanto no período matutino quanto no vespertino, composto principalmente por mulheres jovens e crianças.

Alguns profissionais citados no projeto de pesquisa não compõem a USF.

O quadro atual de profissionais que integram a USF selecionada é composto por: médico generalista (02), enfermeiro (02), cirurgião-dentista (02), psicólogo (01), médico psiquiatra (01), fisioterapeuta (01), terapeuta ocupacional (01), fonoaudiólogo (01), agentes comunitários de saúde (11); auxiliar de enfermagem (05), auxiliar de consultório dentário (01) e técnico de higiene dentária ${ }^{19}(0)$.

Surgiram dificuldades quanto à disponibilidade para realização das entrevistas por parte dos profissionais devido às ausências por férias e licença maternidade.

Através do contato pessoal, as entrevistas foram agendadas respeitando as escolhas dos profissionais quanto ao dia, horário e local. Somente 02 profissionais escolheram realizar a entrevista fora do horário e ambiente de trabalho.

Obteve-se um total de 15 entrevistas, que tiveram duração média de 02 horas e 30 minutos. Aquelas que foram realizadas no mesmo ambiente de trabalho apresentaram limites quanto ao local: ruídos, muitas interrupções e receios dos entrevistados pela possibilidade de serem ouvidos quanto tratavam de assuntos mais sigilosos.

As entrevistas foram gravadas, transformadas em MP3 e transcritas para análise.

O grupo focal com profissionais de nível técnico (auxiliares de enfermagem e atendente de consultório dentário) não foi possível realizar pelo pouco número de participantes dada a falta de disponibilidade principalmente dos auxiliares de enfermagem, em

${ }^{19} \mathrm{O}$ técnico de higiene dentária (THD) é um profissional de nível técnico que compõe a Equipe de Saúde Bucal. A direção administrativa e os profissionais dessa Equipe justificaram a ausência deste profissional pelo número pequeno de ESF e falta de espaço físico para realização do trabalho simultaneamente. 
número reduzido (um profissional estava de licença médica e outro foi demitido), de deixar seu posto de trabalho.

Neste sentido, foi reformulada a proposta e realizada entrevistas com estes profissionais também.

Já o grupo focal com ACS ocorreu após alguns descompassos entre as informações dadas pela direção administrativa e pelos profissionais quanto ao melhor momento para realização deste. Houve confusões no dia agendado, o que gerou atrasos e agitação nos participantes que não sabiam o que fazer.

O grupo foi realizado em duas tomadas, com duração média de 02 horas, devido à abrangência dos temas e a quantidade de relatos de casos/situações apontados pelos participantes. O local escolhido foi a capela, espaço utilizado para grupos e reuniões, que fica ao lado da USF.

A pesquisadora se colocou enquanto mediadora do grupo e 02 auxiliares de pesquisa, uma para cada tomada, foram relatoras. Além disso, o gravador foi utilizado para auxiliar a confecção dos relatórios.

Portanto, o campo foi realizado durante 03 meses e teve a participação de 26 profissionais de saúde que compõem a equipe multiprofissional da USF selecionada.

Foram entrevistados:

- Equipe nuclear: médico generalista (02), enfermeiro (02), auxiliar de enfermagem (03);

- Equipe ampliada:

o Saúde Bucal - cirurgião-dentista (02) e auxiliar de consultório dentário (01);

o Saúde Mental - psicólogo (01) e médico psiquiatra (01); 
o Reabilitação (Equipe de Saúde da Pessoa Portadora de Deficiência) fisioterapeuta (01), terapeuta ocupacional (01) e fonoaudiólogo (01).

Foi realizado 01 Grupo Focal com ACS em duas tomadas, sendo que na primeira houve a participação de 10 ACS e na segunda, 07 ACS.

Embora desconhecendo os procedimentos de finalização desta pesquisa, a USF como um todo, em diferentes momentos de entrevista e grupo focal, solicitou uma devolutiva considerando a importância do tema.

Agendou-se um retorno à USF para apresentação e entrega da dissertação no primeiro semestre de 2009 após conclusão e defesa da mesma.

\subsection{CUIDADOS ÉTICOS DO ESTUDO}

O presente estudo foi submetido ao Comitê de Ética em Pesquisa da Secretaria Municipal de Saúde do Município de São Paulo - CEP/SMS e à Comissão de Ética para Análise de Projetos de Pesquisa - CAPPesq da Diretoria Clínica do Hospital das Clínicas e da Faculdade de Medicina da Universidade de São Paulo, que analisaram e aprovaram emitindo os pareceres ${ }^{20}: n^{\circ} .316 / 07$, de 27 de dezembro de 2007 e $n^{\circ} .1104 / 07$, de 30 de janeiro de 2008, respectivamente.

Para a abordagem dos participantes da pesquisa foram considerados aspectos éticos da portaria 196/96 - Termo de Consentimento Livre e Esclarecido ${ }^{21}$; sendo que todos os participantes assinaram o termo antes de conceder a entrevista e de participar do grupo focal.

Preserva-se em sigilo o nome dos participantes, bem como o do serviço de saúde escolhido como sítio da pesquisa.

\footnotetext{
${ }^{20}$ Vide anexo A.

${ }^{21}$ Vide anexo B.
} 


\section{CAPÍTULO 6 - ANÁLISE TEMÁTICA DO MATERIAL EMPÍRICO}

A análise do material empírico (dados advindos das entrevistas e do grupo focal) segue a orientação da técnica de Análise de Conteúdo Temática.

Em termos de tratamento dos depoimentos colhidos, nas entrevistas semi-estruturadas e grupo focal, utilizamos o 'método de interpretação de sentidos' que buscam interpretar o contexto, as razões e as lógicas de falas, ações e inter-relações entre grupos e instituições (GOMES et al., 2005).

$\mathrm{Na}$ trajetória analítico-interpretativa, percorremos os seguintes passos: a) leitura compreensiva, visando à impregnação, visão de conjunto e apreensão das particularidades do material da pesquisa; b) identificação e recorte temático que emergem dos depoimentos; c) identificação e problematização das idéias explícitas e implícitas nos depoimentos; d) busca de sentidos mais amplos (sócio-culturais), subjacentes às falas dos sujeitos da pesquisa; e) diálogo entre as idéias problematizadas, informações provenientes de outros estudos acerca do assunto e o referencial teórico do estudo; f) elaboração de síntese interpretativa, procurando articular objetivo do estudo, base teórica adotada e dados empíricos.

Destaca-se que no tocante ao grupo focal, por sua especificidade de buscar o caráter coletivo da produção de sentido, a análise privilegia também, os consensos e discordâncias processadas pelo grupo.

Numa primeira abordagem do material, o conteúdo das entrevistas e do relatório do grupo focal foi dividido e classificado através de 03 recortes temáticos que apontam para um desenho de análise, vislumbrando o aprofundamento e a síntese interpretativa, conforme explicitado acima.

Os 03 recortes temáticos são: trajetórias e percepções (a trajetória dos profissionais até o momento atual no contexto do PSF, bem como suas percepções sobre estrutura e funcionamento do serviço em que trabalham); relação 'serviço de saúde e comunidade' 
(aspectos do serviço de saúde, a relação com a comunidade e as demandas e necessidades médico-sociais no cotidiano desta relação) e compreensões temáticas (a percepção dos fenômenos: violência, uso abusivo de álcool e drogas, e saúde mental, pelos profissionais).

Para a análise do material produzido, utiliza-se o recurso conceitual das representações sociais.

A representação social é uma modalidade de conhecimento particular, resultante de atividade psíquica ligada a valores, normas e regras sociais, cuja função é a de elaborar conhecimentos, comportamentos e comunicação entre indivíduos (MOSCOVICI, 1978).

Moscovici (2007) considera que todas as interações humanas pressupõem representações. Se estas forem menosprezadas, apenas sobrarão trocas, ou seja, ações e reações não específicas e empobrecidas na troca. Portanto, ele afirma que:

o que é importante é a natureza da mudança, através da qual as representações sociais se tornam capazes de influenciar o comportamento do indivíduo participante de uma coletividade. É dessa maneira que elas são criadas, internamente, mentalmente, pois é dessa maneira que o próprio processo coletivo penetra, como fator determinante, dentro do pensamento individual (MOSCOVICI, 2007, p.40).

O indivíduo ao representar reproduz um objeto que pode ou não ser socialmente valorizado. Deste modo, a representação não pode ser analisada apenas como um reflexo de um objeto na consciência individual ou coletiva enquanto reprodução do real. Esta possui um caráter ativo uma vez que a reprodução implica em remanejamento das estruturas, reconstrução de dados e remodelação de elementos (MOSCOVICI, 1978, 2007).

Para ele, o indivíduo cria, repensa o objeto, reexperimenta-o e o refaz. Logo, há uma grande liberdade para a atividade mental àquele que se empenha em apreender um dado externo, já que este dado jamais será algo acabado e unívoco (MOSCOVICI, 1978).

Ao trabalhar a noção de representação social, o autor reabilita a experiência vivida e reconhece a possibilidade de diversas racionalidades em que diferentes grupos têm visões distintas de um mesmo objeto e maneiras diversas de conhecer e lidar com o saber. Assim, faz 
uma revalorização do senso comum, do saber popular, do conhecimento cotidiano ao abordálos como um sistema coerente de signos ao contrário de como eram considerados: confusos, inconsistentes ou equivocados (ALENCAR, 2006).

Alencar (2006) evidencia uma questão relevante. A ‘mão contrária’ na troca entre universos científicos e cotidianos não é problematizada por Moscovici. Este autor discute apenas a apropriação por parte do senso comum sobre o conhecimento científico, mas não enfatiza a possibilidade da ciência ter contribuições do mundo ordinário, ou seja, abstém-se da questão sobre como se mesclam esses dois tipos de conhecimento, em ambas as direções.

Compreende-se, portanto, que a teoria desenvolvida por Serge Moscovici (1978, 2007), o primeiro a introduzir o conceito de representações sociais e trazer à cena o conhecimento do senso comum e a relação entre os conhecimentos especializados e cotidianos no campo da psicologia social contemporânea, também traz importantes contribuições para esta análise.

\subsection{TRAJETÓRIAS E PERCEPÇÕES}

\subsubsection{TRAJETÓRIA E INSERÇÃO NO PSF}

Como citado anteriormente, a USF foi uma das primeiras a serem implantadas no Município de São Paulo por estar em uma área considerada 'bolsão de pobreza,22. Esta unidade integrou um projeto-piloto vinculado às esferas estadual e federal, e em parceria com entidades filantrópicas, o Programa QUALIS/PSF; sendo municipalizada em 2001.

O grupo de participantes do estudo tem como característica peculiar um número expressivo de profissionais que estão desde o início dessa implantação no território, há aproximadamente 10 anos de tempo de serviço.

Nos relatos, há certo saudosismo dos que participaram do processo de implantação, quanto à atenção desempenhada pelos propositores e coordenadores do Programa através de

\footnotetext{
${ }^{22}$ Ver nota $n^{\circ} 17$
} 
capacitações e acompanhamentos diários. Estes últimos enfatizavam a inversão do modelo tradicional de saúde, que priorizava as ações curativas para uma compreensão centrada na família e ampliada do processo de saúde e de doença.

O PSF quando começou tinha um outro tipo de apoio, uma outra realidade política, que era maravilhosa. (...) priorizava a inversão, do curativo para investir no preventivo, que afinal esse é o nosso objetivo. Mas existe uma pressão muito grande, cada vez maior da gente reinverter, (...) voltar ao tradicional (Letícia, fisioterapeuta).

diferente de outras unidades, parece que as coisas [aqui] conseguem se manter mais. As construções não se perdem. (...) houve mudanças, mas você vê que boa parte dos agentes comunitários que começaram (...) permaneceram ao longo de todos esses anos. Isto é um diferencial, porque as pessoas têm essa 'história na veia' (...). São pessoas que trazem o que nessa época, no início do Programa foi muito investido em termos de capacitação. Então, consegue-se alimentar um pouco no restante do grupo (Aline, fonoaudióloga).

É marcante a rotatividade dos profissionais de nível superior, principalmente, médicos e enfermeiros. Atualmente, os que estão na USF possuem no máximo 02 anos de tempo de serviço.

Não se inserir na residência médica (por opção ou não), após a conclusão do curso de graduação e a falta de profissionais são fatos que justificam o porquê do PSF ter se tornado uma possibilidade de primeiro emprego nos últimos anos para médicos. Isto reforça o curto período de permanência na ESF para aqueles que objetivam se inserirem no próximo ano em uma residência médica.

Vim por indicação. Eles estavam precisando de médicos. (...) e eu estava [tentando] a residência para saúde da família. Não passei. E aí a mãe de uma amiga falou: "Você não quer vir trabalhar?" É o que eu sempre quis, tanto que ia fazer residência nisso (Amanda, médica).

Os ACS que representam parte do grupo mais antigo no serviço, defendem que se mantiver a configuração inicial de trabalhadores é relevante para a manutenção dos ideais precursores do Programa. Entretanto, observa-se que não necessariamente aqueles que estão há mais tempo na USF detém a maior integração e vínculo com a comunidade. 
Mesmo os profissionais com mais de 05 anos de trabalho sentem dificuldades em relatar situações, casos, experiências relacionadas às demandas e necessidades médico-sociais da comunidade. Ou seja, discorrem em seus relatos as atividades técnicas, curativas e tradicionalmente aceitas da sua função profissional, sem ampliar as percepções e explorar atividades multidisciplinares e coletivas diante do cotidiano na atenção primária à saúde.

Em contrapartida, profissionais com apenas 01 ano de trabalho compreendem que reconhecer as demandas e necessidades médico-sociais de uma comunidade exigem maior integração e vínculo com a mesma, e isto, compete ao trabalho integrado em equipe do cotidiano na atenção primária à saúde. No capítulo seguinte será aprofundada esta discussão.

Quanto ao tempo de formação, os 11 profissionais de nível superior possuem de 01 a 27 anos. No intervalo de 01 a 10 anos, 08 profissionais; de 11 a 20 anos, 2 profissionais; e acima de 20 anos, 1 profissional. Do número total, 08 possuem pós-graduação, sendo 03 na área de Saúde Pública e Coletiva.

Sabe-se que no PSF há a justificativa em priorizar a contratação de profissionais recém-formados, pela maior adesão destes diante das novas propostas de atuação diferentemente daqueles que têm muito tempo de experiência em hospital ou em serviços tradicionais (LOPES; PALMA, 2005). Considerando os anos de implantação do Programa e os dados, observa-se que a maioria dos profissionais está no intervalo de 01 a 10 anos de formação reiterando esta idéia.

Quanto aos 04 profissionais de nível técnico, o tempo de formação varia de 05 a 22 anos, sendo que no intervalo de 05 a 10 anos, 03 profissionais, e acima de 10 anos, 01 profissional. Ressalta-se que dois dos três auxiliares de enfermagem tiveram experiência anterior como ACS em outras USF da região.

Dos 11 ACS participantes, 08 possuem ensino médio completo; embora não seja exigida qualificação específica, basta que o ACS seja morador da comunidade onde atuará. 
Com exceção do cirurgião-dentista e do psiquiatra que trabalham 20 horas semanais, os demais profissionais trabalham 40 horas semanais, e todos são contratados em regime celetista por instituição parceira da Secretaria Municipal de Saúde de São Paulo (SMS-SP).

Percebe-se que a construção das trajetórias dos profissionais de saúde até à inserção no PSF é marcada pela polaridade: a opção ou a contingência que o levou ao emprego.

Assim, os relatos transitam entre o desejo, a vontade, o interesse, a curiosidade de trabalhar numa proposta que se mostra diferenciada ao incluir as visitas domiciliares, o trabalho em equipe e a aproximação com as famílias e a comunidade; e a oportunidade de emprego com remuneração atrativa para aqueles que estão desempregados ou querem aumentar salários, apesar de não pretenderem atuar nesta área dentro do setor saúde.

Poucos profissionais mesclam estas idéias:

achava interessante a idéia de visitar, quer dizer, de conhecer as famílias, ver o paciente no próprio ambiente, porque aí você vê as relações familiares e como isto interfere, e pode ter uma intervenção maior junto à família e a comunidade. Ver outras formas de integração, (...), essa é uma razão. A outra [razão], o salário era compensador. Era um salário duas vezes maior do que se ganhava no outro local (Romeu, psiquiatra).

Dos 26 profissionais, 15 possuem experiência anterior de trabalho no setor saúde, sendo que destes 09 relataram experiência na atenção primária. Os demais não trabalharam e nem tiveram experiências anteriores na saúde.

fui trabalhar em hospital, meu primeiro emprego, clínica médica cirúrgica. De lá pra cá foram várias experiências: medicina preventiva, resgate, prontosocorro adulto e infantil, maternidade (Roberta, enfermeira).

em 2000 comecei a trabalhar com o PSF. Trabalhei (...) de 2000 a 2004 numa mesma equipe, numa cidade pequena do interior de Mato Grosso do Sul. (...) por ser uma cidade pequena, além de fazer o PSF, fazia a parte da urgência e emergência. Eu trabalhava muito com a sala de parto (Marta, médica).

Nunca pensei em trabalhar na saúde. Era costureira. Depois me 'enfiei' em uma associação para trabalhar com movimento de moradia e aí despertou aquela coisa de comunidade (...). (...), já estava cheia de trabalhar como voluntária. Nunca tinha ouvido falar no PSF. (Raquel, auxiliar de enfermagem). 


\subsubsection{O SERVIÇO DE SAÚDE: ESTRUTURA E FUNCIONAMENTO}

A USF é um local totalmente adaptado, cedido por uma comunidade religiosa e não uma construção planejada para ser um prédio público e de saúde. O seu espaço físico é bastante restrito e com muitas divisórias que formam salas adaptadas, as quais não favorecem a execução de atividades e a privacidade necessária aos profissionais e usuários.

Todos os profissionais mencionaram a estrutura física da USF como limitadora das atividades cotidianas, bem como do desenvolvimento produtivo do trabalho como um todo.

o que decepciona aqui não é a população, não são os funcionários, não é o nosso trabalho. O que decepciona aqui é o nosso espaço físico, que é horrível, é insalubre, é tudo de ruim. Você vê mofo e água caindo para tudo quanto é lugar. Uma sala sem privacidade (...). Você não tem lugar, tudo é apertado, tudo é pequeno. Você quer fazer uma atividade diferente, não tem onde fazer. Você vai se limitando a fazer só aquilo que é o normal, que é o corriqueiro, não sai disso (Marta, médica).

O espaço físico é terrível. A minha sala é totalmente inadequada para o trabalho. (...) aqui não tem privacidade nenhuma, o que eu falo aqui a outra sala escuta, [e vice-versa]. (...) nesses oito anos sempre foi a briga dos diretores passados, mas não tem como. É uma região que não pode ficar sem posto de saúde e não tem como ampliar (César, cirurgião-dentista).

senti muito, porque as outras unidades que trabalhei eram novas (...). A gente não tem nada de estrutura praticamente para trabalhar aqui. É cadeira velha, chão que está abrindo, (...), essas coisas dificultam nosso trabalho. Se a gente tivesse um ambiente melhor, um lugar, um equipamento mais adequado, a gente poderia desenvolver com mais facilidade o trabalho (Telma, cirurgiãdentista).

A unidade possui dois andares. No primeiro andar encontra-se a recepção, um corredor

onde os usuários permanecem como se fosse uma sala de espera; uma sala onde se realizam as atividades de coleta de exames, curativos, medicações e observação de pacientes em repouso; um corredor onde estão os armários dos funcionários e materiais de higiene e limpeza; a sala de vacinação; outro corredor, utilizado para fazer os procedimentos de inalação; uma mesa em frente à escada, que serve de apoio para o laboratório (informações e pastas de exames) e agendamento de grupos; e uma capela.

Não se pensou sobre qual era a necessidade para cada sala. (...). Deveria ter uma sala especial para coleta, toda azulejada, com cantos arredondados, com balcão de acrílico para facilitar a higiene, cadeiras e espaço para o 
profissional circular lá dentro. (...) acaba ocorrendo acidentes, riscos biológicos para os profissionais, estresse (...), deveria ser tudo separado, sala de curativo, sala de medicação, sala de coleta, sala de observação. Aqui é tudo numa única sala, extremamente pequena. A janela (...) se você deixar aberta, (...) entra rato. É um espaço, que se fosse por mim, interditava (Simone, enfermeira).

As entradas da unidade e da capela são independentes, mas ficam uma ao lado da outra. O espaço da capela serve como 'coringa' para realização de grupos, reuniões gerais, reuniões de equipes, capacitações, dentre outras atividades, principalmente, por comportar aproximadamente 50 pessoas.

No segundo andar, encontra-se a farmácia; um corredor onde tem um balcão e um computador para os ACS registrarem suas atividades e administrarem as pastas de cadastramento de famílias e usuários, e um arquivo de documentos de funcionários; a sala da Equipe de Saúde Bucal; a sala da administração; a copa; o escovódromo; um banheiro unissex para os funcionários; dois consultórios; a sala da enfermagem; a sala da direção e a sala de espera.

A circulação de ar dentro da USF é dificultada por não existirem janelas, e sim vitrôs, que estão extremamente próximos das construções dos vizinhos. Com o objetivo de melhorar a circulação, colocaram um tubo de ventilação que capta o ar no único banheiro e distribui para os demais espaços, grande falha citada pelos profissionais, pois ao ser ligado expande o mau cheiro por vários terminais após o uso do banheiro. Mesmo assim, a tubulação não é inutilizada, pois há a necessidade de ar quando há mais de 20 pessoas no segundo andar.

não têm janelas (...). Aí puseram o tubo de ventilação, (...) em cima da privada do banheiro. É uma coisa boa de engenheiro que pensa, porque qualquer pessoa que usa o banheiro vai o cheiro todo nesses terminaizinhos. (...). A sala da direção simplesmente não dá para usar. Três pessoas na sala, você não consegue respirar, porque não ventila. (...) tem que ligar também, porque às vezes tem grupo [no espaço da sala de espera] que cabe vinte, trinta pessoas e não respiram (Simone, enfermeira).

A unidade está num momento muito ruim de estrutura, de pintura, de água minando. Está faltando uma manutenção, a gente tem uns problemas crônicos de ventilação, de escada, que paciente não consegue subir para sala de odonto ou para pegar remédio (Luana, terapeuta ocupacional). 
A dificuldade de acessibilidade (escada estreita e íngreme) e a falta de disponibilidade de espaços diante do número total de profissionais limitam as atividades, ora extinguindo-as, ora apontando para que sejam até realizadas fora da USF.

Não se pode ter um consultório dentário com escadas e sem rampa. Eu fazia tratamentos de pacientes deficientes. Pedia para carregar o paciente (...) para o andar superior. Aí a coordenação teve que mandar encerrar, porque se o paciente sofresse algum acidente, a culpa era do profissional. (...) tive que realmente parar, porque eram duas ou três pessoas subindo na nossa escadinha (César, cirurgião-dentista).

faço [grupos] naquele espacinho da sala de espera quando tem alguma coisa acontecendo na capela. (...), mas procuro otimizar bastante os espaços que tenho fora da unidade. (...) tem dois CEDECA. Então, desço [o morro] e (...). (...) o grupo de idoso não dá para acontecer lá, (...), porque descer escada, com casca de fruta, com tudo que eles jogam no meio da viela. Se cair, um paciente, um idoso que está indo para o grupo, como que eu vou ficar? Aí não dá. Mas as pessoas mais 'durinhas', os adolescentes, acabam descendo (Simone, enfermeira).

Como visto, a precariedade das instalações físicas, as limitações para o desempenho das atividades no cotidiano, além de problemas quanto à manutenção (infiltrações, torneiras e equipamentos quebrados) e higiene (proximidade com depósitos de lixos favorecendo o aparecimento de insetos e ratos), acabam gerando desânimo, desmotivações e estresses nos profissionais.

O escovódromo (...) usado para fazer a escovação das crianças está com problema nas torneiras. Agora é feito como? Só simulação (...)! Então, a gente leva [a criança] lá na frente do espelho e ensina a escovar, só simulando (Simone, enfermeira).

A gente trabalha aqui por amor mesmo, porque é bem desumano. (...). Isso aqui não foi projetado, aproveitou um restinho, um espaço e foi transformado numa UBS. (...), não tem sala de observação, não tem sala para curativo, não tem para [coleta de] papanicolau, não tem sala para coleta de exames, a gente vai se virando com o que tem. (...). É desgastante, difícil e às vezes causa até insatisfação (Raquel, auxiliar de enfermagem).

Muitos consideram que a estrutura física da USF é um descaso pelos anos de existência no território, um descaso com os profissionais e, principalmente, com a população.

na verdade isso aqui nem deveria ser uma unidade de saúde, porque deixa muito a desejar. Falta muita coisa, é tudo muito precário, as paredes, a umidade, a gente não tem um lugar decente pra trabalhar (Camila, auxiliar de enfermagem). 
Alguns relatos dos profissionais sugerem que a USF foi aberta por reivindicação da população, ou seja, não surgiu por iniciativa pública, e sim, por um movimento de lideranças comunitárias do local. Por estar razão, foi feito todo um rearranjo estrutural para comportá-la inicialmente.

A USF está localizada na entrada de uma favela, um entroncamento de ruas que também serve de entrada para as pessoas ligadas ao tráfico de drogas. Antigamente, este local era tido como 'terra de ninguém’, com troca de tiros entre os representantes do tráfico e da polícia em qualquer horário do dia.

Para alguns profissionais, a presença de um equipamento público de saúde, como a USF, representa algum tipo de ordem, limite, enfim, a entrada do Estado no território da favela. Isto desencadeou mudanças na dinâmica das relações ali constituídas, diminuindo a violência. Entretanto, reconhecem que esta diminuição é relativa, já que muitas situações relacionadas à violência e ao tráfico de drogas estão cada vez mais escondidas.

quando foi construída, eles [gestores] pensaram na questão da comunidade para diminuir os índices de violência (...). Esse ponto que a unidade está era desova de corpos. Matavam as pessoas e traziam para este local, por isso a idéia da capela. (...). Então, para reduzir isto entrou a saúde, porque quando circula a mãe do traficante, a gestante do traficante, há um respeito. (...) foi uma estratégia (Simone, enfermeira).

Embora existam todas essas problemáticas enquanto estrutura física, a USF como um todo é coesa, organizada, acolhedora e tem um bom funcionamento, segundo os profissionais.

por estranho que pareça é um dos lugares que nunca faltou consultório para eu atender (...). (...) tive muita interação com as colegas que são médicas de família, facilidade para conversar, discutir. (...). (...) foi o local que percebi mais próximo a interação (...). É lógico que é pequeno, mas funciona razoavelmente bem (Romeu, psiquiatra).

funciona bem na medida do possível (...). Mesmo sendo muito pequeno, sem ter lugar para fazer, a gente consegue realizar, (...), tanto que a gente sempre cumpre as nossas metas em tudo, vacina, consulta, e atendimento [específico] (Marta, médica).

Há uma ajuda múltipla entre os profissionais e determinação em realizar ações de saúde para a comunidade: atendimentos em visitas domiciliares, atendimentos na unidade 
(acolhimentos e consultas agendadas), exames laboratoriais, grupos (prevenção, orientação, educação, saúde da mulher, saúde da criança, saúde do adulto, saúde do adolescente, etc.) e atividades educativas e intersetoriais (creches, escolas, Conselho Tutelar, dentre outros).

A unidade se propõe a tentar ultrapassar aquilo que é um protocolo esperado do PSF. (....) dar conta de outras coisas mais educativas, de atividades coletivas. (...) consegue fazer uma busca ativa, discriminar as necessidades, direcionar isso para atividades de grupo para dar conta de ampliar e oferecer outras estratégias do que só o atendimento individual. E nisso eles funcionam bem, programam bem (Rebeca, psicóloga).

A USF possui $02 \mathrm{ESF}$, que se relacionam com as 'equipes ampliadas': Equipe de Saúde Bucal, Equipe de Saúde Mental e Equipe de Reabilitação.

tem a terapeuta ocupacional, a fisioterapeuta e a saúde mental que ajudam. (...) se tem um acamado, vai a médica, a enfermeira, a TO, a fono, a fisio. E aí tenta fazer um atendimento conjunto numa casa. (...) dá para gente sentar, olhar [e discutir o caso]: "Ele está precisando disso. Está precisando daquilo. Eu vi isso.” (Amanda, médica).

O fato de ser uma unidade pequena e com apenas 02 ESF é valorizado pelos profissionais, que acreditam ter maiores possibilidades de integração e cumplicidade do que em outras USF opostas a esta. As discussões, brigas e atritos são evitados pela proximidade no cotidiano de trabalho; o que favorece a permanência e evita a rotatividade costumeira do PSF.

é uma equipe muito unida, todos são muito companheiros. (...) no nosso início foi (...) complicado, porque aqui era muita violência. (...) e era muito simples fazer atendimentos e não saber quem estava atendendo. Mas as agentes comunitárias sabiam (...). Então, às vezes você tinha que fazer um tratamento e as agentes davam um aviso, para saber quem era quem. (...) até já teve de um cara (...) bater a mão na arma para ser atendido (César, cirurgião-dentista).

Há um aspecto desfavorável quanto ao tamanho da unidade: ao ocorrer a falta de um profissional, seja por motivos de adoecimento, férias ou qualquer outro. Isto interfere diretamente no funcionamento da USF, causando sobrecargas de trabalho aos demais.

Em diferentes relatos, os profissionais de nível superior assinalam que os ACS são bastante envolvidos com o trabalho, sendo poucos os que possuem distanciamento do cotidiano das práticas em saúde. Percebem também que estes profissionais por estarem 
cotidianamente inseridos no território possuem alto grau de sofrimento, ansiedades e estresses por se depararem com as dificuldades de entendimento do fluxo, do modo da unidade operar, e de pedidos e solicitações inviáveis da comunidade.

Quanto ao funcionamento das ESF, os entrevistados ressaltam: o bom relacionamento entre os profissionais; a participação ativa dos integrantes na divisão de tarefas; a execução de ações na busca ativa por demandas, não apenas aguardando os usuários; o surgimento de propostas criativas a partir de pequenas ações que decorrem do conhecimento peculiar das dinâmicas familiares; e a apropriação das necessidades dos usuários baseadas em dados sociais, culturais e epidemiológicos.

Sabe-se que houve momentos de competição entre as ESF 1 e 2, mas nos últimos anos têm conseguido trabalhar, criar projetos e impactar a população conjuntamente, tanto que alguns profissionais já consideram que esta USF possui apenas uma grande equipe.

é uma UBS pequena: são dois médicos, dois enfermeiros, onze agentes comunitários e cinco auxiliares de enfermagem. (...) é muito pouco, não tem como você não integrar, não tem como a equipe 1 não participar da equipe 2, assim a gente trabalha junto. É lógico que cada equipe faz o seu serviço, mas sempre estamos juntos, principalmente nos grupos (...). Agora não é só da área 1 ou só da área 2, é da unidade (Marta, médica).

Alguns profissionais marcam a ocorrência de conflitos, discussões e diferenças de opiniões dentro da ESF, entretanto, consideram que estas divergências produzem construção para o trabalho multidisciplinar.

Observam-se diferenças entre as ESF quanto ao modo delas se relacionarem com o trabalho, dadas as realidades das áreas em que atuam, o tempo de ação diante de uma situação-problema, as características próprias de seus integrantes e os processos de mudanças em suas conformações de equipe por entradas e saídas de profissionais.

a equipe 1 (...) é mais aberta para falar e resolve ali na hora. É rápida. (...). A equipe 2 é (...) mais fechada, mais difícil de trabalhar, tem que ir um pouco pelas entrelinhas. (...) a própria população divide: a área 2 é favela e área 1 não (Roberta, enfermeira). 
tem um grau de sofrimento muito grande, principalmente na equipe 2, que tem a área mais complicada em termos sociais e uma população com baixa escolaridade (Rebeca, psicóloga).

a equipe 1 (...) era totalmente desandada, nada funcionava, tanto é que equipe 2 que era o 'top'. Depois, (...) mudou muitas coisas. (...) os pacientes começaram a interagir [mais], (...), e a equipe virou outra. Foi mudando os médicos, (...), e todos que vieram também colaboraram muito com a equipe (Camila, auxiliar de enfermagem).

Acho que a equipe 1 trabalha mais redondinho, mas até pela estrutura [de área]. A área é mais tranqüila, é carente, mas não tanto como a área 2. (...). Além de que o adoecimento da área 2 também é maior, até pela estrutura de moradia, (...) são mais barracos. Mais gente morando dentro do mesmo barraco e não tem nenhuma ventilação (Raquel, auxiliar de enfermagem).

\subsubsection{TERRITÓRIO DE ABRANGÊNCIA}

Como dito anteriormente, a USF está localizada na entrada de uma favela e cobre uma área onde quase cem por cento dos usuários cadastrados são moradores desta ocupação. Podese dizer que o território de abrangência corresponde a algumas ruas na parte alta próxima à unidade e aos dois barrancos, morros repletos de vielas onde se localiza a favela.

No encontro dos morros havia um córrego, que era chamado de 'buracão'. Apesar deste ser canalizado e até já ter uma nova rua, o nome 'buracão' permanece, bem como as atitudes da população diante dele ao jogar lixos desde cima dos morros, que se acumula nas encostas e gera problemas relacionados à falta de higiene como a proliferação de insetos e ratos.

A área da ESF1 possui um melhor acesso físico, embora haja contrastes: duas microáreas possuem ruas asfaltadas com rede de esgoto, casas bem estruturadas e população usuária de convênios médicos; e as outras quatro micro-áreas são vielas localizadas no morro, sem saneamento básico, as moradias são barracos e a maioria dos usuários é exclusiva do SUS (SUS - dependentes).

A área da ESF2 o acesso físico é mais dificultoso e todas as micro-áreas estão localizadas na favela. Suas vielas são mais fechadas, estreitas, inclinadas e com degraus que chegam até sessenta centímetros de altura. A maioria das moradias são barracos em precárias 
condições. Possui um lixão, esgoto a céu aberto e até uma bica de água contaminada. Há muita sujeira e mau cheiro.

O acesso ao território como um todo é repleto de obstáculos, justamente por ser um lugar estratégico para a circulação e esconderijo das pessoas ligadas à violência e ao tráfico de drogas.

é uma área difícil mesmo. (...) às vezes a gente percebe que alguns lugares são estratégicos, por causa da população, já que tem muita droga (Roberta, enfermeira).

Sabe-se que parte da população coberta pela área 1 não circula na área 2, principalmente, por medo e preconceito.

O que prevalece, (...), é que ainda tem o medo pelas coisas que aconteceram que foram mais na área 2. (...) chacinas mesmo, [problemas] de drogas e todas as outras coisas mais de ruim aí no meio (Roberta, enfermeira).

No ponto de vista dos profissionais, ambas as áreas possuem moradias bem próximas, com pouca ou quase nenhuma privacidade, mas que também promovem a interação interpessoal.

É muito interessante, é tudo muito junto. Então, o que acontece na casa do vizinho, eu ouço; eu nem estou querendo ouvir (...). É tudo aberto e todo mundo é íntimo de todo mundo (Luana, terapeuta ocupacional).

a primeira visita que fiz: desci aquelas [vielas], então vira numa, passa dentro do quintal do outro, sobe uma escada, desce... Percebi uma coisa muito curiosa: que havia uma interação muito grande entre as pessoas. Bem diferente do que vejo, por exemplo, na classe média. (...). Mas nunca vi tanta interação como lá, quer dizer, lá as pessoas, uma vai e conversa com a outra. (...) está tudo ali no meio, muito próximo (Romeu, psiquiatra).

Entretanto, a comercialização informal e a ocupação de terreno por não pagantes geram muitas brigas, desentendimentos e até mortes. Além disso, a construção desenfreada de moradias localizadas nas encostas dos morros possui riscos constantes de deslizamentos.

como é que cabe tanta casa uma em cima da outra. As construções (...) aparecem assim, você entra num beco e não sabe onde vai sair. É meio que um labirinto. Você fica impressionada de ver como que as pessoas constroem as casas, é uma engenharia deles. Você pensa isso: "Não fica de pé e fica.” (Telma, cirurgiã-dentista). 
Há uma proximidade do território com pólos petroquímicos, sendo um dos motivos da ocorrência de síndromes raras no local, segundo alguns profissionais.

umas síndromes meio raras (...), que tem a ver com a poluição da água, com os pólos petroquímicos que estão muito próximos daqui. Enfim, têm algumas coisas que a gente levanta neste sentido, porque só acontecem nessa região (Letícia, fisioterapeuta).

É um território formado por uma população cuja maioria é migrante do Norte e Nordeste, com diferentes hábitos culturais e que têm muitas dificuldades em se inserir profissionalmente dada a sua baixa escolaridade, o que favorece a inserção no "trabalho escravo’ e não reconhecido.

percebo várias situações até porque chega muitas deficiências instaladas, deficiência auditiva, tendinites, dores (...). (...) você vê uma relação direta com alimentação inadequada e com a situação de trabalho ruim. Então, é aquela pessoa que trabalhou 40 anos na fábrica sem ter nenhuma proteção auditiva (...). (...) ainda hoje aqui tem um trabalho escravo grande, de exploração mesmo. (...) pessoas que vivem de costura, que vão em fabriquinhas próximas daqui, mas que tem que trabalhar um absurdo para ganhar. Cem peças para ganhar dez reais. (...) tem um pai de um paciente nosso, (...) que ele montava mil carrinhos para ganhar um centavo por carrinho (Aline, fonoaudióloga).

Como as pessoas migrantes vêm de uma situação muito precária, aos poucos, amigos e familiares vão se agregando no mesmo barraco daqueles que chegaram primeiro, na esperança de conseguirem melhores condições de vida na cidade de São Paulo. Logo, as famílias cadastradas na USF são extremamente populosas.

A gente tem uma família numa mesma casa com vinte e duas pessoas. Não são casas grandes, é tudo barraco, é tudo pequenininho, tudo apertado. (..). Eu não vejo que eles se ajudam muito não. (...) eles acabam recebendo as pessoas às vezes por falta de opção mesmo. (...). É muito precoce a sexualidade para [as crianças]. É comum, porque numa casa de três cômodos moram doze pessoas, sendo três casais. Como que faz sexo nessa casa? Todo mundo participando ali no mesmo quarto, no mesmo ambiente (Simone, enfermeira).

Muitas crianças chegam à USF com a demanda de dificuldades de aprendizado na escola. Entretanto, para os profissionais esta demanda é muito mais relacionada com as vulnerabilidades do território, sendo que vão desde o convívio com pais analfabetos ou que possuem baixa escolaridade até as dificuldades familiares de prover proteção e cuidado como 
por pais em uso abusivo de álcool e/ou outros tipos de drogas, sem rendas, que deixam seus filhos à mercê das ruas.

Problematizam também a atual distorção do papel da escola, que além de ter a preocupação exclusiva quanto à freqüência de crianças e adolescentes, passou a ser um espaço de uso e tráfico de drogas.

por mais que a maioria das crianças e adolescentes estejam freqüentando, isto não quer dizer que estejam estudando ou que tenham uma boa educação (Amanda, médica).

fui conversar com a coordenadora pedagógica da escola daqui da frente. (...) $\mathrm{O}$ ano passado eles tinham os alunos que apontavam e sabiam quem usava drogas, mas não usavam dentro da escola. Esse ano piorou muito, entrou um grupinho, que está usando dentro da escola. Então, está bem difícil (Simone, enfermeira).

Grande parte das pessoas é analfabeta e com escolaridade inferior a oitava série do antigo ensino fundamental. Há um alto índice de desemprego, tanto de homens, mulheres e jovens. Os profissionais reforçam a idéia de que quanto menos estudo, menos condições as pessoas da comunidade têm de valorizar o próprio trabalho.

Assim, a presença constante do tráfico de drogas denota relações contraditórias de garantia de emprego, poder e segurança aos que lá moram e até trabalham.

Chega final de ano eles têm cesta de natal. No dia das crianças, eles têm festa com carrinho de 'yopa'. É uma coisa muito bem organizada, muito forte. "Eu não tenho emprego, eu não tenho estudo. O que que eu posso fazer?" "O que está de oferta ali no meu ambiente?” O que eles têm de mais oferta no ambiente deles é o tráfico, infelizmente é o tráfico (Simone, enfermeira).

há um respeito muito grande, por parte da população [do tráfico], tanto é que a nossa unidade aqui nunca foi roubada. (...) é um aliado. Não sei se por bem ou por mal, mas estamos trabalhando mais tranqüilos aqui. Da época que a gente iniciou o trabalho, não é nada (César, cirurgião-dentista).

A pobreza, a miséria, a fome e outras tantas faltas marcam os relatos dos profissionais, que questionam o agir em saúde e até compreendem o porquê de muitas mulheres brigarem entre si quando há poucas vagas na creche, o lugar onde estas podem garantir a alimentação diária para o filho. 
Briga entre familiares por causa de um pão. Saiu uma briga de uma mãe, porque a filha acordou mais tarde e outra priminha já tinha comido o pão (Simone, enfermeira).

a pobreza que é difícil. (...) não se acostuma, mesmo vendo aquilo todo dia. As pessoas de fora não imaginam, (...) é um monte de gente morando num cubículo e passando fome (Camila, auxiliar de enfermagem).

Eles vivem em condições subumanas, não vivem, sobrevivem. (...). Tem uma questão social que é muito mais importante do que a questão da saúde. (...). Como a gente vai orientar a pessoa a fazer um exercício, sendo que ela não está comendo? Você vai orientar a pessoa a arranjar uma cama hospitalar, se não cabe nem uma cadeira de rodas dentro da casa dela (Letícia, fisioterapeuta).

às vezes você vai fazer algum procedimento, uma cirurgia e chega na pessoa: "Você comeu?" "Não, não comi nada." (...). O risco que se corre é maior no trabalho, porque são pessoas desnutridas, debilitadas (Telma, cirurgiãdentista).

tem bastante criança nas creches aqui. As mães deixam nas creches. A maioria delas não trabalha, mas deixa mesmo a criança passar o dia até por causa de alimentação (Andréa, auxiliar de enfermagem).

Para os profissionais, as vulnerabilidades da maioria da população do território, que

pode ser caracterizada como sendo muito jovem, denunciam uma realidade social complexa:

iniciação sexual precoce, gravidezes na adolescência, uso abusivo de álcool e drogas,

aliciamento sexual e pelo tráfico de drogas, e falta de expectativa de vida.

No dia que a gente (...) levou a vacina [para] os trabalhadores que estavam catando lixo, chegou um molequinho de oito anos (...). Ele é soro positivo. Aí virou para mim: “Tia, você não tem uma vacina para Aids?” É complicado. (...) Como que é trabalhar com essa criança? Como que é a sua sexualidade? E falei: "Por que você quer uma vacina para Aids?” (...). "Porque comecei namorar e não quero que a minha namorada pegue." "Mas o que é namorar para você?” "Ah, ela faz sexo oral comigo.” Apenas oito anos de idade (Simone, enfermeira).

Muitas gestantes adolescentes, (...), que já tem três, quatro filhos. Mães de dezenove anos com quatro, cinco filhos (Amanda, médica).

Se você está nas vielas, você vê as crianças com as latinhas de lançaperfume, cigarrinho de maconha, com as bolotinhas de pedra (...). Se eu não tenho o mínimo pra sobreviver, preciso pelo menos esquecer de como vivo. (...) é o meio que se encontra de fugir dessa realidade, (...). Além de que esse mundo das drogas dá um suporte para eles, tanto que quando um moleque aqui é o olheiro, (...), se ele é pego nesse momento que está trabalhando, a família vai receber um salário e o que eles chamam de ‘jumbo’. (...), a cesta [básica] que a família tem que levar semanalmente para o presídio (Simone, enfermeira). 
Quanto aos equipamentos do território, percebe-se que muitos dos profissionais não moradores desconhecem, até mesmo pontuando que são inexistentes. Entretanto, ao enumerálos se obtém um número expressivo: o Centro de Defesa da Criança e do Adolescente “Monica Paião Trevisan” - CEDECA; o Espaço Gente Jovem - EGJ, relacionado à área de assistência social da SMSP; o Alcoólicos Anônimos - AA; o Centro de Direitos Humanos de Sapopemba - CDHS; o Conselho Tutelar - CT; o Cantinho da Esperança; o Núcleo de Apoio ao Cantinho da Esperança - NASCE; a Pastoral da Criança; 03 escolas (02 municipais e 01 estadual); 01 creche municipal; 01 biblioteca e igrejas de diferentes denominações.

O CEDECA e o CT são os equipamentos mais recorrentes nos relatos dos profissionais. O primeiro por possuir um espaço utilizado para atividades da USF e o segundo pelas situações/casos que implicam em intervenções conjuntas.

Os profissionais das ‘equipes ampliadas’ de Saúde Mental e de Reabilitação, por priorizarem em suas diretrizes o desenvolvimento de ações intersetoriais, foram os que tiveram maior propriedade para expor sobre os demais equipamentos do território.

a região é rica em termos de equipamentos. (...) tem o CEDECA, que é bastante atuante, tem duas igrejas que são bastante atuantes, inclusive no espaço de uma igreja funciona o equipamento da assistência social, o EGJ. Tem o CDHS (...) e que junto com o CEDECA dispara algumas ações de assistência jurídica, assistência de caráter social e psicológico (...). (...) a Pastoral da Criança, que tem algumas agentes [comunitárias de saúde] que estão ligadas, e que fazem parte especificamente nessa área que eles falam que é o 'buracão.' O CEDECA montou agora uma sede (...), que irá ter alguns cursos profissionalizantes (Rebeca, psicóloga).

você vê que é uma comunidade que tem vários recursos. (...) quem construiu estes recursos se baseou no índice de desenvolvimento humano, [ou] foi a própria população que se organizou. (...) a biblioteca que é nova, sei que foi uma luta popular; o espaço novo do CEDECA foi uma luta popular, (...). Os outros espaços, imagino que sejam assim (Luana, terapeuta ocupacional).

Segundo os profissionais, há poucos espaços de lazer no território, sendo que a brinquedoteca foi desativada recentemente.

O único espaço [de lazer] que tinha era a escola, mas por questão política e mudança de direção foi fechado o espaço de final de semana. (...) foi uma perda. Eles não têm nem rua, é tudo viela (Simone, enfermeira). 
tem o campo de futebol, mas não é todo mundo que consegue usar, (...), falta cinema, falta lazer, essas coisas é um pouquinho longe. (...) tem uma praça que há pouco tempo foi reformada (...) acho que é a única coisa que tem mesmo que dá pra usar aqui perto (Luana, terapeuta ocupacional).

um dia a gente abriu o posto para lazer (...). A única parte que teria para usar seria a escola, mas a escola não abre mais de fim de semana. No fim do ano a gente fez gincana com criança, (...), tudo para tentar uma interação. (...) foi uma parte lúdica, porque a nossa brinquedoteca não está funcionando direito. (...) nossa brinquedoteca era minúscula, pequeníssima, e estava com um problema sério de ratos (Amanda, médica).

Bares e botecos preenchem o cenário do território, caracterizando-se como um espaço de lazer pelos jogos de sinuca, baralho, dominó e o uso de bebida alcoólica. Neles se encontra a maior parte da população masculina adulta.

As mulheres adultas são donas-de-casa, não trabalham e não possuem espaços de lazer. Fato que os profissionais justificam presença constante delas na USF.

Neste item, destacamos outras polaridades que permeiam a análise do material de estudo: as percepções dos profissionais moradores do território e dos que não são moradores. Isto reforça a divisão entre os ACS e os profissionais de nível superior e técnico, respectivamente.

O território de abrangência é bem marcado pelos entrevistados não moradores, que o lêem, desde o seu ingresso neste território, como marcado pela pobreza e miséria; repleto de ‘faltas’ (saneamento básico, lazer, moradia adequada, dentre outros).

O tempo de atuação não alterou a concepção inicial destes profissionais, poucos relatam que se acostumaram com o que vêem.

Os ACS que são também moradores, em grupo focal, apresentam discordâncias sobre as percepções acerca do território. Este ora é visto com apreço, por ser parte da história de vida (infância, adolescência e juventude) com cenas ricas em detalhes, ora é repudiado pela pobreza, falta de saneamento básico, presença do tráfico de drogas e da violência.

Percebe-se, ainda, dificuldades em pontuar os preconceitos para aqueles que lá moram (ACS), embora as discussões reflitam que são existentes. Isto pôde ser apreendido no relato 
de uma ACS que revelou a necessidade de um familiar mentir sobre o bairro de moradia para ser aceito em uma seleção de emprego.

\subsubsection{COTIDIANO DE TRABALHO}

Para maior clareza este item será descrito segundo o que cada categoria profissional relatou.

\section{Equipe nuclear}

\section{Médicos}

O cotidiano é bastante dinâmico e suas atividades são: acolhimentos (escuta dos usuários em situações de emergência); consultas agendadas (consultas de clínica médica, como consultas de crianças menores de um ano, gestantes, hipertensos, diabéticos); reuniões diárias de equipe (reunião para discutir e decidir estratégias com os demais profissionais da equipe, casos e situações da área); grupos (de hipertenso e diabético, de criança menor de dois anos, de crianças entre três a cinco anos, de crianças de seis a doze anos, de resultado de exames, de troca de receitas, de planejamento familiar, de gestantes, ' $100 \%$ leve', de idosos, de adolescentes); e visitas domiciliares, priorizadas e agendadas em reunião de equipe.

As visitas domiciliares geralmente são feitas para aqueles que não conseguem vir no atendimento na USF (acamados, restritos ao lar, em pós-cirúrgico); usuários resistentes a tratamentos, com doenças crônicas ou com amputação de membros; famílias que precisem mudar hábitos e situações para evitar adoecimentos. Mas caso necessite como, por exemplo, uma puérpera, tanto de uma cesária quanto de um parto normal, a visita será realizada.

Há a participação nas demais atividades propostas pela USF: reunião geral, reunião de conselho gestor, passeio com a comunidade, gincana com as crianças, gincana de idosos, gincana de gestantes e campanhas, as quais promovem ações de saúde e integração, por exemplo, o "Dia da Saúde Bela” (dia de cuidados de beleza e higiene para as mulheres da comunidade). 


\section{Enfermeiros}

Observam-se diferenças nos relatos do cotidiano desses profissionais; um deles está recentemente na USF por cobrir licença maternidade de outro profissional e expõe que somente realiza atividades previstas por um cronograma.

sou [nova] na unidade. Não sei se é medo, talvez receio de colocar algumas coisas pra mim, talvez (...) por não me conhecerem a fundo, não saber do potencial que a gente tem. (...) já percebi que me poupam (...), justamente por saber que vou ficar aqui pouco tempo (Roberta, enfermeira).

Já o outro profissional, discorre muitas atividades que compõem seu cotidiano: consultas de enfermagem, reuniões diárias de equipe, coletas de exames das gestantes, grupos fixos da equipe (idosos, hipertensos e diabéticos, prevenção à saúde), visitas domiciliares. É profissional de apoio no laboratório e no curativo, supervisora do exame de papanicolau e responsável pelos setores de vacina e planejamento familiar.

Diante das demandas e necessidades da comunidade, participação na criação e organização dos grupos: Grupo de adolescentes (espaço de escuta de adolescentes abordando temas de prevenção de doenças e drogas), Grupo Vitória (um espaço de escuta e acolhimento de mulheres) e Grupo 100\% Leve (acompanhamento, incentivo e motivação para redução de peso e adoção de um estilo de vida saudável). Os dois primeiros grupos são realizados em parceria com o CEDECA.

Também participa das demais atividades propostas pela USF: reunião geral, passeio com a comunidade, gincanas, campanhas e caminhada matinal.

Não adianta falar para os usuários: "Vai lá fazer caminhada.” Não tem ninguém da unidade fazendo caminhada. Eles têm que ver que a gente também pratica, que também realiza, que está junto ali e tem as mesmas dificuldades que eles têm (Simone, enfermeira).

\section{Auxiliares de enfermagem}

A equipe de auxiliares de enfermagem apresenta-se bem integrada, compartilhando ajudas sem a necessidade de uma escala rígida para organização do trabalho. 
As atividades que compõem o cotidiano são variadas: atendimentos, reuniões diárias de equipe, visitas domiciliares, grupos, auxílios na vigilância à saúde e nas notificações de doenças compulsórias, vacinação, inalação, verificação de pressão arterial, medicação, curativos e observação de usuários em repouso. Há um destaque para as atividades do laboratório (coletas de exames e organização dos resultados), que seguem uma rotina diária.

às vezes a rotina quebra, por exemplo, quando está sem funcionário. Então, nem sempre são as mesmas pessoas que vão subir para colher [os exames], (...). Mas sempre acontece a coleta (Camila, auxiliar de enfermagem).

Nos relatos, os auxiliares problematizaram o aumento das cobranças quanto ao cumprimento de metas, a sobrecarga de trabalho e a falta de tempo, o que impede as participações deles em atividades importantes para o trabalho em equipe, tais como reuniões diárias de equipe, visitas domiciliares e atividades coletivas para a comunidade.

Rotina maçante (...). A gente não consegue mais entrar num grupo e participar. É só a demanda: medir pressão, pegar exame, fazer vacina, fazer curativo. Rotina de auxiliar mesmo, como se fosse auxiliar de PS. (...). Tudo é muito corrido (...). Tem uma perda (...). Não tem mais qualidade (Andréa, auxiliar de enfermagem).

\section{Agentes Comunitários de Saúde (ACS)}

As atividades que compõem o cotidiano dos ACS são: cadastramentos de usuários e famílias da micro-área de atuação, vigilância em saúde, reuniões diárias de equipe, visitas domiciliares, reuniões com equipes ampliadas para discussões de casos, grupos e atividades coletivas e intersetoriais (CEDECA, escolas, creches, etc.).

Também participam das demais atividades propostas pela USF, tais como reunião geral, reunião de conselho gestor, passeio com a comunidade, gincanas, campanhas, caminhada matinal, dentre outras.

\section{Equipe ampliada}

\section{Saúde Bucal}

Esta equipe é formada por 02 cirurgiões-dentistas e 01 auxiliar de consultório dentário. À proporção que se coloca para o trabalho de referências é de 01 cirurgião-dentista para 01 
ESF e 01 ACD para 02 ESF. Nesta USF, um dos cirurgiões-dentistas é contratado por 20 horas semanais, diferentemente dos demais profissionais.

\section{Cirurgiões-Dentistas}

As atividades que compõem o cotidiano dos cirurgiões-dentista são: reuniões de ESF e da USF; visitas domiciliares; avaliações das famílias e seus componentes; grupos de orientação em saúde bucal; grupos de tratamento inicial (Grupo de TI); grupos de tratamento restaurador atraumático, o qual detém a progressão da doença cárie (Grupos de ART); atendimentos de emergência e urgência; atendimentos específicos agendados na USF e atividades educativas em creches e escolas.

Auxiliar de Consultório Dentário (ACD)

O ACD auxilia o cirurgião-dentista fornecendo o material de consumo e permanente, que é o chamado trabalho a quatro mãos; cuida do material odontológico (esterilização e abastecimento da sala); realiza e participa de grupos de orientação em saúde bucal e atividades educativas em creches e escola; e participa de reuniões de ESF e da USF esporadicamente.

\section{Saúde Mental}

Os profissionais desta equipe trabalham como duplas de referências para ESF (psicólogo ou terapeuta ocupacional e psiquiatra) em diferentes USF. Os psicólogos ou terapeutas ocupacionais, contratados por 40 horas semanais, estão distribuídos na proporção de 01 técnico de saúde mental para 04 ESF. Já os psiquiatras, contratados por 20 horas semanais, têm a proporção de 01 para 14 ESF.

\section{Psicólogo}

As atividades que compõem o cotidiano do psicólogo são: reuniões de ESF com ESM mensais (neste espaço se dá a organização dos agendamentos e discussão de casos/ situações de famílias mais conflituosas); atendimentos individuais e grupais na USF; atendimentos em 
visitas domiciliares realizados em conjunto (ESF e ESM); discussões diárias de casos/situações com integrantes da ESF; intervenções nas questões da infância encaminhadas por creches, escolas e Conselho Tutelar; atividades multiprofissionais (orientações, atividades psicoeducativas com famílias e crianças, brinquedoteca, etc.) integrando ESF, ESM e Equipe de Reabilitação; realização de grupos por temas e necessidades da USF; participação nos grupos fixos já existentes da USF; articulações e intervenções intersetoriais através de discussões de situações/casos em escolas, Conselho Tutelar, CEDECA, etc.; e participação nas atividades gerais propostas pela USF.

\section{Psiquiatra}

O psiquiatra está na USF uma vez por mês e suas atividades são: atendimentos junto com a dupla de referência em saúde mental; discussões de situações/casos com os médicos de família; capacitações para ESF de como intervir em saúde mental; visitas domiciliares e participação em grupos de acolhimento em saúde mental.

\section{Reabilitação}

Os profissionais desta equipe trabalham enquanto trios de referências para ESF (fonoaudiólogo, fisioterapeuta e terapeuta ocupacional) em diferentes USF. Cada trio é referência para 16 ESF. Como a USF possui 02 ESF, este trio está pelo menos dois períodos semanais na unidade.

\section{Fonoaudiólogo}

Este profissional fez uma diferenciação dos primeiros anos do Programa com o atual momento. Enfatizou que no início do trabalho havia um enfoque maior na prevenção e promoção na área de reabilitação permitindo ações coletivas e intersetoriais. Com o tempo isto se modificou, dada a sobrecarga de atendimentos de demandas específicas na USF.

As atividades que compõem o cotidiano do fonoaudiólogo são: atendimentos específicos individuais e grupais; reuniões mensais de ESF com a Equipe de Reabilitação; 
atendimentos e visitas domiciliares; atividades integradas com as ESF e ESM; parcerias com a Equipe de Saúde Bucal; participação em grupos propostos pela USF e ações intersetoriais pontuais através de discussões de situações/casos em creches, escolas, CEDECA e etc..

\section{Fisioterapeuta}

As atividades que compõem o cotidiano do fisioterapeuta são: atendimentos e visitas domiciliares priorizando usuários restritos ao lar, acamados, idosos que sofrem quedas freqüentes e aqueles que não têm condições de ir à USF e nem ao ambulatório; atendimentos na USF aos usuários com deficiência respiratória, seqüelas de acidente vascular cerebral, amputados e às crianças com atraso no desenvolvimento global; atividades preventivas (orientações); grupos (orientação postural, dores, crianças); participação em grupos fixos da USF, por exemplo, o grupo de puericultura junto com a ESF para detectar algum atraso no desenvolvimento; e discussões de situações/casos com os ACS.

\section{Terapeuta Ocupacional}

As atividades que compõem o cotidiano do terapeuta ocupacional são: acolhimentos com horários ‘coringas’ para uma demanda aberta, ou seja, as ESF podem agendar usuários que não têm nenhum encaminhamento nas mais diversas queixas, já conhecendo previamente o trabalho da terapia ocupacional no PSF; discussões de situações/casos com os ACS; atendimentos individuais de demandas específicas da terapia ocupacional na USF; atendimentos e visitas domiciliares; grupos (relaxamento, adolescentes); participação em grupos fixos da USF; intervenções intersetoriais (creche e escolas); atividades explorando novos espaços da comunidade, por exemplo, a biblioteca.

\subsubsection{RESULTADOS DAS AÇÕES}

Os profissionais entrevistados ao serem questionados sobre a percepção dos resultados de suas ações individuais, revelam que os obtém através de retornos dos próprios usuários que 
dão continuidade aos tratamentos, das visitas domiciliares, de alguns dados do SIAB, dos relatórios e planilhas feitas diariamente, e das avaliações durante os planejamentos.

dá para ver o resultado do seu trabalho (...), porque você faz um tratamento completo com seu paciente. (...) dá para acompanhar o seu trabalho (...). Quando vê um paciente que você fez um trabalho e vingou, vamos dizer assim, é muito interessante (César, cirurgião-dentista).

quando a gente se reúne em alguns períodos de planejamento, fica mais claro ver o impacto sobre cada ação. O que a gente faz ao longo do ano parece aquela coisa de formiguinha, (...) é até difícil visualizar o resultado, mas acho que os levantamentos estatísticos que são feitos acabam favorecendo (...). (...) consegue fazer uma análise do envolvimento do funcionário individualmente e em grupo, das equipes, além da população se colocar também (...). (...) e quando a gente junta elementos mais subjetivos e os dados estatísticos consegue ver que tal aspecto reduziu ou não (Aline, fonoaudióloga).

Percebe-se nos relatos uma dificuldade em pontuar indicadores de avaliação de modo mais sistemático, sendo isto problematizado em apenas um relato.

têm avaliações informais, empíricas, observações, não tem um instrumento de avaliação mais preciso, que [realmente] pretenda avaliar (...). Com os recursos tecnológicos de hoje, você não ter um banco de dados que funcione, que seja comum é complicado. Você fica trabalhando só no manual. (...) Se eu não voltasse para discutir [o caso] e se a equipe não o trouxesse, perderia a continuidade. Além de ter um território com uma grande demanda de interfaces, a equipe não dá conta de fazer o monitoramento de todos (Rebeca, psicóloga).

Quanto à percepção dos resultados das ações coletivas da USF, os profissionais os percebem através do uso do serviço pela comunidade, do aumento na adesão de usuários em grupos propostos pelas ESF, da integração da ESF na produção de intervenções conjuntas, e também, de alguns dados do SIAB.

pela adesão de grupo. (...) você pede para vir uma pessoa, aí vem a vizinha atrás, a rua inteira. Esse que é o resultado do trabalho da equipe, da ação do agente comunitário, a resposta da consulta médica e dos acompanhamentos da enfermagem (Simone, enfermeira).

Os profissionais afirmam que até o momento atual obtiveram os seguintes resultados: poucos casos de crianças desnutridas e desidratadas; ótima cobertura vacinal de crianças; poucos idosos sem cobertura vacinal e acompanhamento; diminuição dos casos de depressão em idosos; diminuição de gestação em adolescentes que participaram do grupo de 
planejamento familiar; maior adesão de métodos anticoncepcionais oferecidos pela rede pública; maior agilidade nos processos de métodos definitivos para planejamento familiar; intervenções em escolas com adolescentes prevenindo o uso abusivo de drogas; redução de cárceres privados; diminuição de casos de crianças recém-nascidas com deficiência; diminuição de casos de AVC e de amputação; maior controle dos hipertensos e diabéticos cobertos pela USF.

tinha uma demanda reprimida, imensa no ano passado, de pacientes esperando a adesão do planejamento familiar para métodos definitivos. A gente conseguiu zerar isto no ano passado. Então, a pessoa que está hoje aguardando, ela está dentro do prazo da lei, sessenta dias e não mais três, quatro anos (Simone, enfermeira).

adolescente ainda é muito difícil trabalhar, mas você vê que cada vez mais a equipe não desiste. De um ano e meio para cá, por exemplo, você vê um trabalho mais fortalecido. Na reunião de equipe, a enfermeira apresentou um trabalho que está fazendo na escola e que consegue conversar com os adolescentes (...), ao ponto deles verbalizarem que estão usando drogas e se disporem em colocar os nomes numa lista, para poder fazer um trabalho junto com a equipe de saúde em redução de danos. Conseguir isto é fantástico! (Aline, fonoaudióloga).

Também pontuam aspectos e/ou situações que não obtém resultados, tais como: casos

de uso abusivo de álcool e drogas em diferentes faixas etárias; casos de depressão em mulheres jovens; reabilitação e inclusão de pessoas com deficiências na comunidade.

Outros profissionais se questionam, o quanto é possível ser resolutivo diante da ausência de uma rede intersetorial e do aumento das demandas e necessidades da comunidade.

essa realidade de pobreza, de favela, esta questão social, faz com que a gente reflita mesmo: Até que ponto a nossa ação aqui sem uma questão social integrada, mais efetiva, (...), é resolutiva? Eu não sei, às vezes penso que nos iludimos um pouco ao achar que conseguimos fazer algumas coisas sem toda essa rede (Letícia, fisioterapeuta).

o resultado não deixa de ser positivo, mas também não abrange a quantidade que tinha que abranger, apesar da gente fazer acima da nossa meta de atendimento via SIAB. Quer dizer, na verdade a gente atende mais de $100 \%$, mas mesmo assim, na minha opinião, não é $15 \%$ do que a população precisaria. Dizem que nós tínhamos três mil e quinhentas pessoas na área, ou seja, em média novecentas famílias na minha área. Só que este é um número que foi dado quando iniciou, (...). O SIAB aumenta este número gradativamente, mas têm muitos agregados (...). Então, um médico para cinco mil pessoas. Como é que um médico, que ele tem em média oito períodos por semana, vai conseguir atender essas cinco mil pessoas? Não 
consegue. Você consegue sim as prioridades, que são os hipertensos, diabéticos, crianças menores de um ano, gestantes. (...). Acho que por mais que eu faça, representa muito pouco (Marta, médica).

\subsubsection{O TRABALHAR NO PSF}

Para alguns profissionais que inicialmente assinalavam o desejo, a vontade desde a graduação em trabalhar numa proposta inovadora, ao se depararem com a prática revelam limites, dificuldades e frustrações.

A criação do vínculo tão apregoado pelas diretrizes do Programa é dificultosa no momento em que os profissionais entrevistados necessitam delimitar espaços na relação com os usuários.

Eu imaginava totalmente diferente (...), uma visão romântica que você vai conseguir mudar o mundo, mas não dá. É um trabalho desgastante demais. A criação de vínculo é difícil, porque cria a falta de limite. O paciente não sabe até onde vai (Amanda, médica).

Percebe-se também uma dificuldade em priorizar ações e atividades preventivas e de promoção da saúde, pois justificam que a população reforça o modelo tradicional de saúde ao preferir ações curativas e rápidas.

Não adianta só o remédio se não tiver uma mudança dentro do ambiente, dentro do contexto familiar (...). PSF é isso, não é só curativo, é mais preventivo do que o curativo. Isso que é difícil, a gente mudar a cabeça das pessoas. Para eles é: "Estou doente, procuro o médico, tomo o remédio e passa” (Amanda, médica).

é uma população que não acostuma aderir muito aos grupos educativos. (...) fiquei meio frustrada, porque achava que eles não tinham acesso a este tipo de trabalho (...). Mas, na verdade, não. (...) consegui entender que São Paulo tem uma população medicalizada. É muito mais fácil fazer uma consulta médica, tomar um remédio do que, por exemplo, você aprender como prevenir um problema de lombalgia (Letícia, fisioterapeuta).

eles gostam de vir no pronto-atendimento (...). Por ter mais de dez anos implantado o PSF aqui, eles não têm aquela idéia da prevenção. Eles querem o 'PA' mesmo. Chegar, atender e resolver a queixa dele, naquele dia, naquele momento (Raquel, auxiliar de enfermagem).

Pode-se compreender que não é apenas a população uma limitadora de ações e atividades preventivas e de promoção da saúde. Constata-se nos relatos que diante de 
situações complexas e que geram grandes demandas, preferir realizar ações técnicas previstas, rápidas e curativas mascaram as possibilidades de novas intervenções.

a gente vê muito o PSF funcionando como um pronto-atendimento e não conseguindo dar conta daquilo que se preconiza de fazer promoção de saúde, fazer prevenção. Então, perde-se um pouco esse caráter de saúde comunitária (Rebeca, psicóloga).

Além disso, fatores presentes no território como o tráfico de drogas e a violência, influenciam e limitam o planejamento de intervenções da USF.

têm coisas que fogem da capacidade de intervir. Às vezes, você percebe uma situação que é muito difícil ter o que fazer, (...) principalmente, em determinado tipo de sofrimento que está vinculado à violência. (...). Tem coisas que a gente fica tentado a fazer (...). Recentemente uma enfermeira fez uma proposta para mim. Ela queria fazer um trabalho de prevenção da dependência de drogas. Acho extremamente interessante e necessária, mas não sei se tenho coragem de fazer. Acho que não. Vai mexer diretamente ali com os traficantes, o tráfico. Isso pode ser uma coisa perigosa, complicada (Romeu, psiquiatra).

Outros profissionais ao serem questionados sobre o trabalhar no PSF, revelam que gostam do desafio do trabalho, bem como da sua comunidade alvo. Consideram-no como uma excelente estratégia, embora percebam que o processo de mudança dos padrões de adoecimentos para os de saúde e qualidade de vida seja moroso. Também valorizam a atuação centrada na família, a visita domiciliar, o trabalho em equipe e a junção da equipe nuclear com as equipes ampliadas de Saúde Bucal, Saúde Mental e Reabilitação.

Para estar aqui tem que primeiro gostar do que faz e por quem faz. (...) Quando lá na caminhada você vê as pessoas que passaram no grupo com você, (...) esse é o melhor momento que pode existir. A sementinha que você plantou, está brotando. (...) trabalhar no PSF é plantar muitas sementes. Você tem que gastar muita saliva, que não é na primeira vez que vai conseguir persuadir na decisão da outra pessoa (Simone, enfermeira).

sinto que faço a diferença, não sozinha, porque efetivamente eu faço parte de uma equipe (...). Aqui vemos pessoas (...). É verdade, vemos as famílias. E isto exige não só conhecimento técnico (...), mas um amadurecimento enquanto sujeito a cada dia (Luana, terapeuta ocupacional).

as propostas das equipes de apoio, saúde mental, reabilitação, odonto, (...) enriquecem. (...) você começa a trabalhar com famílias e vê que isso é efetivo. Consegue trabalhar não naquele modelo só biomédico, mas ter um olhar para questões que vão além da doença (...). Você consegue pensar de fato (...) na autonomia do usuário, na necessidade do outro. (...) tem muitas 
dificuldades, mas tem um alicerce que permite caminhar na contramão do sistema (Aline, fonoaudióloga).

Diante de tantas mudanças desde a proposta inicial do PSF pelo MS, profissionais desmotivados apontam dissoluções de diretrizes e princípios ideais, o que resulta em ilusões quanto à resolutividade do trabalho, ausência de reconhecimento profissional e cobranças.

Parece que você não chega a lugar nenhum. Faz, faz, faz e está parado no mesmo lugar. (...). Só foi no começo que me deram uns cursozinhos, depois disto, acabou. (...). Não me canso de fazer todo dia a mesma coisa, canso de não ter coisas novas, ver que resolvo entre aspas. (...). A gente consegue melhorar o quê? A qualidade de vida? Não, a gente talvez melhore a situação do dia. Está passando mal, você passa remédio ou vê um resultado de exame. Pronto, é só isso (Marta, médica).

O PSF é mais do que só atender aqui no posto. (...). Hoje a gente só está aqui dentro. Atendimento, atendimento, atendimento. (...). O trabalho tinha que ser mais de campo (...). Senão você não trabalha no PSF, fica trabalhando no pronto-socorro, só esperando o doente chegar para atender. Não é isso. Tem que ir lá, ver a família, tratar antes de acontecer (Andréa, auxiliar de enfermagem).

Não sei se é o tempo. Se já estou cansada, se é o local ou a própria questão de estrutura da unidade. (...) com as mudanças [políticas], vieram cobranças. Pouco reconhecimento e muitas cobranças. Eu antigamente valorizava muito mais o PSF do que agora (Camila, auxiliar de enfermagem).

Entretanto, ressalta-se a presença de profissionais que apostam na proposta do PSF e

assinalam a necessidade de superações diante de um território tão complexo de demandas e necessidades.

é uma proposta interessante de acessar, de fazer vigilância de saúde, de estabelecer ações no território. Mas acho que em alguns territórios, comunidades específicas, a equipe mínima mesmo com uma referência de saúde mental e de reabilitação é muito pouco para dar conta das necessidades. [Deveria ter] mais gente para potencializar outras atividades e enriquecer em termos de ações. (...) ter outros profissionais de referência para pensar outras prioridades, por exemplo, saúde do jovem, saúde da mulher, saúde mental com enfoque de gênero (...). Uma equipe de saúde da família não consegue dar conta disto se não tiver um apoiador, uma figura técnica responsável por puxar as ações. Então, outros profissionais faltam para dinamizar outras frentes. (...) a atenção básica é a porta mesmo do sistema e onde mais lida com a pessoa em contexto e em comunidade (Rebeca, psicóloga).

O trabalhar no PSF pelos ACS se configura na ambigüidade: ser profissional de saúde e ser da comunidade. 
A afirmação dialoga com a discussão dos autores Cohn, Nakamura, Cohn (2005), os quais assinalam essa indistinção atribuída pelo PSF ao introduzir na equipe de saúde o ACS:

"borra” a possibilidade de delimitar de forma clara as relações estabelecidas entre as esferas pública e privada da vida social e permite, ao mesmo tempo, que a primeira se confunda com o próprio Estado. Atuando como uma "dobradiça” entre essas duas esferas, os ACS permitem operacionalizar o que parecia incompatível ou de difícil aproximação na proposta de mudança de modelo de atenção enunciada no PSF (p.183).

Assim, alguns ACS também demonstram em grupo focal que estão numa posição privilegiada e diferenciada da própria comunidade que pertencem por serem profissionais de saúde. Gostam de auxiliar os usuários e idealizam obter melhores condições financeiras através deste emprego.

Outros diante do cotidiano repleto de solicitações da comunidade, sem limites de horários e dias da semana, desejam se mudar da comunidade objetivando a diminuição das interferências dos outros em sua vida, mesmo que isto implique em perder o emprego ${ }^{23}$.

Percebe-se no grupo focal que pertencer à comunidade significa ter proximidade, conhecer casos e situações de vizinhos e familiares, e consequentemente, ter a responsabilidade de ser um ‘porta-voz’ no serviço de saúde.

há agentes comunitários que não têm total percepção disto, mas existe uma apropriação muito grande das necessidades dos usuários, o conhecimento da vida de cada um, dos modos de vida, das dificuldades (Aline, fonoaudióloga).

[Os usuários] reconhecem (...) no agente de saúde, uma pessoa que promove saúde, limpeza, coisas que vão ajudar na qualidade de vidas deles. Percebo muito isto em VD, a relação que os usuários têm com os agentes (Letícia, fisioterapeuta).

Contudo, angústias, frustrações e sofrimentos desencadeados pelo cotidiano são percebidas nos relatos dos ACS e profissionais que com eles convivem.

os ACS têm dificuldades, porque vem com toda a ansiedade, com todas as cargas dos problemas socioeconômicos e biológicos que tem dentro da

\footnotetext{
${ }^{23}$ Um dos requisitos para exercer a função de ACS é residir na área da comunidade em que atuar há pelo menos 02 anos.
} 
favela. (...) e eles querem resolver a problemática que estão enfrentando (Simone, enfermeira).

Em diferentes momentos, os ACS externalizam em grupo que os demais profissionais da USF não moradores do território ao se depararem com limites e dificuldades podem se retirar daquele meio, enquanto eles não. A pressão por respostas e soluções permanece constantemente, fazendo os lembrarem que além de profissionais, são também da comunidade.

\section{2. 'SERVIÇO DE SAÚDE E COMUNIDADE' E AS COMPREENSÕES DE}

\section{TEMÁTICAS RELACIONADAS ÀS DEMANDAS E NECESSIDADES MÉDICO-}

\section{SOCIAIS}

\subsubsection{A RELAÇÃO 'SERVIÇO DE SAÚDE E COMUNIDADE'}

Os profissionais entrevistados ao serem questionados se o serviço de saúde em que trabalham atinge os objetivos propostos mostram-se divididos ao elaborarem suas respostas.

Aqueles que consideram que o serviço de saúde não atinge os objetivos, justificam o território insalubre, a população usuária, o espaço físico da USF, as mudanças e desorganizações dos integrantes da ESF, os desgastes dos profissionais ou até mesmo a má administração gerencial da USF como os fatores limitantes para efetivação dos objetivos propostos.

Como um todo não atinge os objetivos. (...). Nossa estrutura física é muito difícil. (...) fica nessa briga de sala e aí já atrapalha o serviço. A gente tenta, por exemplo: “Ah, vamos aumentar o número de grupos.” Mas não tem espaço para fazer. A parte física é uma coisa que atrapalha nosso maior objetivo (Amanda, médica).

Infelizmente não, algumas coisas não dependem da gente. (...). A população é muito difícil (...). Para fazer um grupo você tem que dar alguma coisa para eles, senão eles não vêm. (...) tem que ter um cafezinho, um lanchinho para você chamar atenção para vir (...). E mesmo assim é uma dificuldade muito grande. (...) não é pelas questões da unidade, porque apesar dos problemas físicos (...), carências de material para atender (...), a gente consegue ainda fazer muita coisa. Só que por conta da população ser difícil, a gente não consegue fazer mais. (...) Se a gente tivesse como convencer a população, como fazer com que eles aceitassem, muita coisa talvez iria mudar (Roberta, enfermeira). 
Não atinge os objetivos. (...) vejo que muita coisa falta ainda. (...) a gente vê a insatisfação de alguns pacientes, coisas que não dão muito certo e (...) a área meio descoberta. Não está tendo controle certinho. (...). [Não atinge os objetivos pelas] mudanças de profissionais ou pela própria gerência (...). (...) falta pulso para tomar algumas atitudes, de punir alguma coisa que está errada, de elogiar a outra que esteja certa (Camila, auxiliar de enfermagem).

Outros profissionais afirmam que a USF atinge os seus objetivos, principalmente, por cumprir as diretrizes previstas pelo PSF ao atender grupos prioritários; distinguir dificuldades e falhas no processo de trabalho; reconhecer necessidades da comunidade para além da saúde; e desfrutar de uma boa integração entre os profissionais.

Tem [atingido os objetivos]. (...) cobertura de gestantes, hipertensos, diabéticos, crianças até dois anos. (...) é uma unidade que percebe as falhas e que tem muitas questões que envolvem a intersetorialidade (Luana, terapeuta ocupacional).

Acredito que sim, [o serviço tem atingido os seus objetivos]. (...) tem um entrosamento, integração, trabalho conjunto (Aline, fonoaudióloga).

Nota-se que uma considerável parcela dos profissionais sente dificuldades em constatar ou não o cumprimento dos objetivos gerais e específicos propostos pelo serviço de saúde devido à inexistência estruturada de processos e critérios avaliativos. O teor subjetivo presente nos relatos reiteram esta idéia.

não tenho conhecimento de dados mensais, de tabelas de consulta, de VD, não sei disso, mas tenho a impressão que de uma maneira geral sim, atinge os objetivos (Letícia, fisioterapeuta).

sou muito 'crica' com esse negócio de falar que a gente faz avaliação. Acho que são impressões. (...) a equipe tem coisas que acaba monitorando via SIAB. (...) nunca tive acesso a olhar esses dados. Tinha coisas do tipo: “A gente vai comemorar, porque cumprimos a meta de coleta de papa”. (...) “Ah, a gente cumpriu 100\% da meta de vacinação.” (Rebeca, psicóloga).

Toma-se como um aspecto problemático para o desempenho do trabalho em saúde, os profissionais somente possuírem sensações, impressões acerca do cumprimento dos objetivos da USF. Ao mesmo tempo em que pode ocasionar a desvalorização dos resultados quando cumpridos os objetivos e desmotivações, pode ocasionar o abandono dos ‘alvos’ e percepções 
quanto ao andamento do processo de trabalho, impossibilitando a retomada da missão para a qual a USF foi concebida diante de limites e dificuldades.

A discussão a respeito da relação entre o serviço de saúde e a comunidade é levantada por considerar que esta se dá em um território complexo, compreendendo às vezes, barreiras indissolúveis.

Entende-se, com base no percurso teórico, que buscar uma relação permeável e possível de trocas favorece o reconhecimento de demandas e necessidades médicos-sociais de uma comunidade pela equipe multiprofissional.

Desde os preceitos colocados pelo PSF que a enfatizam até a sua construção a partir das relações interpessoais, a relação 'serviço de saúde-comunidade’ possui concepções diferenciadas por seus atores/integrantes que vão se delineando e consequentemente, influenciando o modo de trabalhar em saúde.

Para o momento, apreende-se dos dados as seguintes concepções dos profissionais acerca dessa relação:

- a relação 'serviço de saúde-comunidade’ é tida como estática e distante, sendo também influenciada pela ineficácia do setor Saúde (aspecto macro);

Para mim não existe relação. (...) só na hora da consulta eles [os usuários] começam a reclamar: "Aqui não funciona! Esse postinho não vai pra frente” (Amanda, médica).

existem casos que não gostam, reclamam, falam que a unidade não presta (...). (...) acho que é uma forma de desabafo, porque a Saúde está realmente um pouco falida (...). Às vezes, a gente se estressa com um paciente, porque ele xinga, reclama, fala. Mas depois você pára, pensa e fala: "É uma humilhação a pessoa ficar pedindo, implorando uma consulta, implorando um exame". (...) dentro do possível acho que eles pensam: "Olha, com isto aqui está ruim, sem isso eu não sei o que seria da gente.” (...) uns oitenta por cento das pessoas pensam assim (Marta, médica).

- a falta de compreensão sobre o funcionamento da USF, o não ser atendido de acordo com as expectativas e as discordâncias incitadas pela comunidade são apontadas como situações ‘esgarçadoras’ da relação ‘serviço de saúde-comunidade’ no cotidiano; 
tem muitas pessoas empenhadas no serviço (...). É lógico que existem problemas de vagas para encaminhamentos e tudo isso, mas às vezes eu tento comparar (...): se tem um convênio e for marcar uma consulta hoje, eu posso demorar três meses para ser atendida, mas eu vou esperar. Já aqui eles não têm paciência. Eles acham que veio hoje, amanhã tem que estar passando. (...) eles têm bastante atenção, têm todas as resoluções dos seus problemas, mas querem tudo na hora (Telma, cirurgiã-dentista).

em termos de vínculo, a comunidade com o serviço, tem. Mas esse vínculo (...) fica quase que em risco de ser quebrado em função de não ser atendido da forma que é a expectativa. Por exemplo: "Ah, eu me dou bem com a agente comunitária, ela é legal e tal. Mas puxa eu nunca consigo passar com o médico.” Não consegue, porque, por exemplo, você é um hipertenso e eles querem direcionar pra um grupo de hipertenso. A pessoa (...) quer ficar passando em consulta todo mês. Então, há essa dissonância entre a expectativa do usuário com o modelo do PSF que está organizado para direcionar para (...) um acompanhamento coletivo. A pessoa tem a sensação de que ser bem atendido, é ter sua consulta mais individualizada (Rebeca, psicóloga).

- o profissional de saúde é responsável em preservar a relação com a comunidade, ou

seja, cabe a ele adotar uma postura, uma linguagem facilitadora;

enquanto profissional, você tem que estar atento para passar a informação de uma maneira fácil, que ele [usuário] consiga entender, participar e assumir isso para vida dele. (...) tem que dar o apoio mesmo, estar ouvindo e identificar o que aquela pessoa está precisando. (...) a necessidade dela. (...), por exemplo, ela chega aqui tossindo, acumulou líquido, está com febre e você manda tomar água por causa do tempo. Você tem que falar tudo. Porque se você falar para ela só tomar água. [Ela vai dizer:] "Mas eu vim aqui no posto para você me mandar tomar água?” (...) você tem que gastar tempo para explicar. Aí quando (...) ela toma água e melhora, na outra semana ela vem falar: "Nossa, sabia que tomei água e foi bom mesmo" (Simone, enfermeira).

- a inserção do ACS possibilita e intermedia a relação 'serviço-comunidade', sendo esta concebida como uma relação próxima e dinâmica;

uma relação legal. (...) é uma unidade que tem uma relação que propõe bastante atividades com a comunidade, as agentes comunitárias são pessoas bastante atuantes. (...) andando com as agentes, fazendo visita, eu percebia a forma delas lidarem com a população e como a população lidava com elas, havia um vínculo positivo. Não era uma coisa assim: "Eu já te falei mil vezes que eu queria isso, você falou com a médica?” Via que tinha uma relação boa, afetiva, de troca (Rebeca, psicóloga).

- os ACS afirmam possuir uma relação de grande proximidade com a comunidade,

mas se contradizem ao acreditar que é uma 'via de mão única', pois muitos usuários não sabem o quanto eles conhecem de suas histórias de vida, sem limites de privacidade. 
Em grupo focal, os ACS debatem outros aspectos da relação 'serviço de saúdecomunidade’ a partir das suas vivências cotidianas. Apontam a dificuldade em se relacionar com necessidades e demandas da comunidade, e em manter a privacidade própria e de sua família quando estão fora do horário de trabalho.

Para os ACS, ser um agente da comunidade significa trabalhar o tempo inteiro, já que os usuários-vizinhos não têm limites quando necessitam de qualquer tipo de informação e/ou ajuda. Sentem-se também insatisfeitos, porque vêem e lidam com situações de conflitos familiares graves no decorrer da semana de trabalho que se perpetuam nos finais de semana. Isto é apontado por eles como um fato diferenciado, pois os demais profissionais da USF que não são moradores da comunidade não têm esta relação.

Para eles, os profissionais que não são moradores da comunidade em que atuam conseguem dissociar nos finais de semana as situações graves, frustantes e limitadoras, presenciadas no cotidiano do trabalho. Acreditam que os demais profissionais vivem melhor, sem se preocupar e influenciar as suas famílias.

Nos relatos de alguns profissionais, não moradores da comunidade, observa-se que diante das complexidades do território corroboram a fala dos ACS. Eles se retiram, ‘desconectam’, para lidarem semanalmente com o trabalho.

eu brinco que a gente tem que ter vida fora daqui do trabalho (...), vê coisas diferentes. Porque se você ficar só casa e trabalho, e ver só esta pobreza e esta miséria o dia inteiro, você acaba ficando um pouco com uma saúde mental alterada. (...) tem que ver que existem outros tipos de vida lá fora, (...). (...) você sabe que vai conviver com isso diariamente. Mas tem que trabalhar a cabeça para conviver com isso da melhor maneira possível. (...) a gente vê muita desgraça, as piores coisas (...) que a gente nunca imagina que vai acontecer (...) acha aqui dentro. Só que você tem que saber separar que aqui é o seu ambiente de trabalho, não é o seu ambiente de vida. A gente tem que saber separar muito bem, isso para conseguir encarar (Telma, cirurgiãdentista).

Apreende-se que este posicionamento influencia as percepções dos ACS, os quais ao discutirem o aspecto de sua relação com a comunidade, marcam seu perfil profissional e não comunitário. Além disso, possibilita a criação de fantasias de potência quanto ao ser 
profissional de saúde, considerando que este pode se 'esquecer nos finais de semana' e se afastar do que realizou no cotidiano de trabalho.

Essa idéia não é verificada na maioria das falas dos profissionais não moradores da comunidade, até porque para que haja integração e relação, situações cotidianas impactarão de alguma forma o profissional de saúde independentemente do espaço temporal (dias, semanas, fins de semanas, meses, anos).

Em meio às discussões com os ACS sobre o assunto, estes concluem que deveria ser repensada a exigência de se morar na comunidade para o ACS, pois trabalham em saúde para cuidar dos outros e não conseguem enquanto moradores cuidar da própria saúde.

Esta conclusão traz uma polêmica ao contradizer justamente uma das características marcantes do PSF: a inclusão de um profissional que tenha destaque em sua comunidade pela capacidade de se comunicar com as pessoas e pela liderança natural que exerce, além do contato permanente com as famílias facilitando o trabalho de vigilância e promoção da saúde ao traduzir para os demais membros da ESF e USF a dinâmica social, as necessidades, as potencialidades e os limites de sua comunidade.

A discussão será retomada no capítulo seguinte quando serão abordados os limites e potencialidades do trabalho em saúde.

Interessante salientar outra concepção sobre a relação ‘serviço de saúde e comunidade’ que surge nos relatos: a USF concebida como espaço da comunidade. A unidade repleta de usuários significa ora a boa relação serviço-comunidade, ora um local para 'compartilhar a vida’ dada às ‘faltas’ de outros espaços e equipamentos no território de abrangência.

uma coisa que aprendi (...), quando a unidade estava vazia era sinal de que tinha uma coisa errada. Se não é um dia de chuva ou um dia de muito frio, a unidade não tem que estar vazia. A população tem que confiar na gente, estar junto com a gente. Não que ela vai vir para passear, vai vir para ser assistida. Não é vir só para o acolhimento da manhã, porque está com dor, febre. Ela vai vir para cuidar da saúde dela (Luana, terapeuta ocupacional).

muitas pessoas vêm aqui só para conversar. (...) não trabalham. Muitas mulheres são donas de casa e quem trabalha é o marido. Elas ficam sozinhas 
o dia inteiro. É filho para cuidar, é casa para arrumar, não tem um lazer, não tem nada. Então, é aqui no posto que elas vêm procurar (Amanda, médica).

Muitas vezes o que eles vêm procurar aqui, a dor não é física, tem uma dor emocional, tem a dor do afeto, tem a dor do aconchego. Tem várias dores que a gente trata aqui que não é dor de medicina, (...) é a dor da alma (Simone, enfermeira).

Contudo, sabe-se que estes aspectos, embora importantes, não se resumem a caracterizar uma relação integrada e compartilhada.

Aprofundando a discussão, vê-se como relevante abordar a dimensão comunicacional da relação, bem como a existência de coincidências entre o que o serviço de saúde propõe e o que a comunidade espera.

A maioria dos profissionais afirma que há comunicação entre o serviço de saúde e a comunidade. Entretanto, no decorrer das entrevistas fazem algumas ressalvas. Primeiramente, diferenciam comunicação de entendimento, ou seja, consideram que existe comunicação, mas não o entendimento da população usuária.

nem sempre os usuários entendem o que o pessoal do serviço de saúde fala, mas há bastante comunicação (Telma, cirurgiã-dentista).

tem comunicação, (...) não tem entendimento. (...) a gente sempre procura explicar tudo (...), às vezes até demais, (...). Agora cabe a pessoa aceitar, (...). Nem sempre a pessoa vai aceitar, porque o que ela quer não é o que a gente tem para oferecer. Porque o PSF é prevenção da família, (...). A pessoa quer é imediatismo, quer que se resolva na hora. Eles estariam satisfeitos com PA, porque não entendem o programa. Isto é uma briga, mas eles não vão entender mesmo (Camila, auxiliar de enfermagem).

Evidenciam que a comunicação é atravancada pela comunidade por falta de informação, vontade, instrução, educação e cultura.

eles [usuários] acham que vindo aqui reclamar, gritar lá na recepção vai resolver e não. (...) a falta de informação, a falta até de educação mesmo. Eles não sabem que se houvesse participação, se tivesse um conselho gestor forte, o posto mudaria. Eles acham mais fácil brigar (...) na recepção, que está mais próxima, do que ir numa palestra, ficar numa discussão. (...) essa comunicação população e unidade fica muito no bate-boca (Amanda, médica).

também é a questão da ignorância, não digo, ignorância de ser estúpido, ignorância da pessoa em não saber, (...), e isso não vai mudar (Camila, auxiliar de enfermagem). 
Existem casos que a pessoa não está nem aí. Parece que não faz sentido. Você fala da importância do paciente, especificamente, não faltar, porque você está prejudicando não ao profissional, que eu estou lá presente, teoricamente estou ganhando o que tenho que ganhar. A diferença é que se ele faltar por faltar, ele vai atrapalhar o seu vizinho, que é o próximo que vai fazer o atendimento, atrasa uma semana da chamada de outro paciente. Ainda nós temos alguns casos de pacientes que nem vem ao primeiro tratamento e sabem da dificuldade que é conseguir um tratamento odontológico, sabe que o valor de um tratamento particular é super alto, sabe disso tudo isso (...). Não sei (...) como explicar mais do que estou explicando. Então, acho que deve ser um problema cultural mesmo (César, cirurgião-dentista).

Por fim, alguns apontam que a comunicação precisa ser melhorada devido às diferentes vivências do profissional de saúde e do usuário; expectativas resultantes do modelo de saúde incorporado pelos usuários (modelo médico-centrado); e ao modo de falar técnico e rebuscado dos profissionais impossibilitando à compreensão dos usuários.

a convicção que tenho é uma, a que a comunidade tem é outra (...). (...) é diferente a gente chegar na (...) pessoa que tem emprego, salário e falar: "Olha, vem na reunião do conselho gestor. Vai ter um cafezinho e a gente irá conversar sobre assuntos da comunidade.” Agora falar para uma pessoa que está com fome, (...), não tem saúde, não tem a primeira necessidade que ela precisa enquanto ser humano. (...) as pessoas falam assim: “Ah, a gente precisa fortalecer o conselho gestor, porque fortalecendo o conselho gestor este será um meio de comunicação maior lá na comunidade.” (...) vai ter um caminho muito longo para se atingir isto. (...) Porque as necessidades dos usuários são outras. (...) às vezes a necessidade do profissional está sendo uma e a necessidade daquele indivíduo é outra (Simone, enfermeira).

O usuário (...) foi escutado pela enfermagem, recebeu a medicação e saiu com a sensação de que não foi atendido. "Não passei com o médico, vim aqui e fiquei falando com esta enfermeira.” (...) a mãe leva o seu bebê (...) com uma tosse e quer passar com o médico. (...). Se [a enfermagem] fizer uma escuta e ver que tem um sinal de pneumonia, (...) aquilo vai subir para (...) a agenda do médico. (...). Só que se não tiver [o sinal], como irá explicar para a mãe: "Olha, a tosse (...) do seu filho não é tosse de passar com o médico, é tosse de passar com a enfermeira.” (...). Ela sai achando que o filho não irá melhorar, porque não passou com o médico. Não foi o médico que viu, foi a enfermeira. Isto é menor do que a ação do médico (Rebeca, psicóloga).

deveria ser uma troca que capacita, que dá condição para o outro ter ferramentas para assumir mais os seus cuidados sem depender tanto. Poder se apropriar do que cabe a ele, se responsabilizar, desenvolver uma autonomia, (...). (...) consigo identificar colegas e equipes que conseguem ter um pouco mais este trabalho. E outros que não (Aline, fonoaudióloga).

Somente três profissionais marcaram a presença do ACS como um 'tradutor', mediador da comunicação entre serviço de saúde e comunidade; sendo que a opinião de um 
deles sobressai ao problematizar os vícios produzidos nos usuários pela descaracterização das funções do ACS.

\begin{abstract}
é claro que o agente comunitário é quem representa [a comunidade], a ponte que liga a família à equipe de saúde. Mas são delegadas a eles funções que não cabem. (...) um exemplo: a questão de o agente ficar que nem um 'pombo-correio'. Vai lá e leva a consultinha. A pessoa falta e leva outra consultinha. (...) por que não se cria uma maneira da vaga estar ali disponível? (...) o usuário tem que ir até a UBS para tomar posse da sua consulta. Parece uma bobagem, mas o índice de faltas ainda é muito grande. Você vê que é muito cômodo para eles [usuários], estão sempre ali esperando chegar à mão. (...) tem o ranço, porque o agente ficou muito viciado nisto. A população também ficou muito viciada e cobra do agente esta maneira de agir (Aline, fonoaudióloga).
\end{abstract}

Ressalta-se dos dados que um número irrisório de profissionais associa a sua dificuldade e do serviço em saúde em se fazer compreender pelos usuários. Nesta 'relação dialógica’, a comunidade é quem tende a ser culpabilizada pelos profissionais.

Diante da discussão sobre a existência ou não de coincidências quanto ao que serviço propõe e o que os usuários esperam, os profissionais se dividem.

Aqueles que afirmam existir coincidências, constatam que as propostas do PSF atingem as expectativas dos usuários baseados no grande número de usuários presentes diariamente na USF, na diminuição de reclamações sobre o funcionamento do serviço, e na cobertura dos usuários doentes em grupos prioritários.

têm coincidências sim, porque senão (...) eles [os usuários] não entrariam nem dentro da unidade. (...) a quantidade de pessoas para atender é preocupante. (...). UBS e PSF que a população não vai para unidade, não procura o serviço é porque alguma coisa está acontecendo. Não é o nosso problema (Roberta, enfermeira).

têm coincidências. (...) oitenta por cento da população é saudável, vinte por cento da população é doente. Estes vinte por cento estão [classificados] em quê? Diabético, hipertenso, doenças crônicas em geral, um avecezado, um paciente que teve um câncer ou coisa do gênero. Alvos das nossas ações (Marta, médica).

Já os profissionais que consideram que não há coincidências, apontam discordâncias nas relações no cotidiano do trabalho e afastamentos do que é preconizado pelo PSF. 
Observam-se as atitudes tanto dos usuários como dos profissionais de saúde, não favorecem às coincidências entre o que o serviço de saúde propõe e o que a comunidade espera.

Ao contrário do que é proposto pelos profissionais de saúde, os usuários esperam ações curativas, imediatas, individualizadas, sendo que às vezes até propõem tratamentos e diagnósticos. Alguns profissionais de saúde se afastam do que é proposto pela USF e PSF ao priorizar somente procedimentos específicos e técnicos, enfim, não conseguem ouvir as demandas e necessidades do outro que está diante dele.

Eles [os usuários] não sabem qual é o papel da UBS. (...). Eles acham: “Agora estou sentindo dor, agora preciso do médico”. (...). O PSF é para não deixar ficar doente, (...), fazer ações antes para depois não ter que fazer tratamento, não ter que [prescrever] remédios (...). Eles acham que aqui é um pronto-socorro igual a qualquer outro. (...) não entendem que o posto é um local que eles têm que ir antes que adoeçam, não depois. "Ah, eu vou fazer um acompanhamento." "Vou fazer um check-up esse ano". (...). "Que legal ali tem um grupo de caminhada, eu li ou eu ouvi que a caminhada ajuda." "Ah, tem um grupo de orientação nutricional." Mas não. "Na hora em que estiver doendo, aí vou lá procurar um médico que é melhor.” (...). É difícil mudar um modelo que sempre foi: "quando estiver doente vá ao médico e procure o pronto-socorro.” (Amanda, médica).

Tem muito paciente que já chega com o diagnóstico. (...). Enquanto você não atende o que ele quer, ele não sossega. (...). Na odonto isto acontece muito, porque chega paciente que você vê que ele não tem necessidade de tirar um dente, mas: "Eu quero!" (...). Aí você fala: "Mas não tem necessidade. Dá para tratar. Você precisa de uma restauração. Dá para fazer um canal." "Ah, mas eu não tenho dinheiro, vou arrancar.” (...) já chegou gente que fala assim: "Quero tirar, porque não quero trabalhar hoje.” (...) tem que ser o que eles querem, na hora que eles querem (Telma, cirurgiã-dentista).

Não há coincidências. (...) as pessoas ainda vêm de um movimento, até por uma questão cultural mesmo, de procurar o especialista. As pessoas ainda não querem passar com um médico de família, um enfermeiro de família. (...) dez anos trabalhando, mas você vê que ainda há uma insatisfação (...). (...) será que essa população não está sendo escutada quando conversa com o profissional? (...). Não sei se todos os colegas têm esta preocupação, (...), isto é um conflito. (...). Muitas vezes também o funcionário está focado só no procedimento e não consegue ter um olhar além, (...), ver se aquele procedimento vai atingir o pedido do usuário ou conseguir criar alguma coisa que atenda mais a necessidade. Se não até colocar para ele o porquê do não para que tenha o esclarecimento. Aí fica mais fácil para o paciente colaborar ou se responsabilizar, entender o processo (Aline, fonoaudióloga). 
Sobre as demandas e necessidades da comunidade que os profissionais mais se deparam no cotidiano de trabalho da USF, estas podem ser enumeradas segundo o grau de ocorrência apresentado nos relatos:

$1^{\circ}$. Aquelas que requerem pronto-atendimento: problemas respiratórios (resfriados, bronquites, pneumonias, falta de ar, etc.), diarréias, febres, vômitos, dores de ouvido e garganta, tosses, verminoses e pediculose. São relacionadas às moradias precárias (casas ou barracos pequenos, sem janelas e higiente) e à falta de saneamento básico pelos profissionais.

$2^{\circ}$. As solicitações de exames gerais e específicos (exames de sangue para diagnósticos de doenças sexualmente transmissíveis, check-up, ultrassonografia, tomografia, ressonância magnética, ecocardiograma, teste ergométrico, eletroencefalograma, raio-X).

$3^{\circ}$. As dores agudas e crônicas; consideram que a maioria da população exerce atividades de trabalho classificadas como braçais.

$4^{\circ}$. As solicitações de atendimentos e consultas com especialistas (ortopedista, cardiologista, fisioterapeuta).

50. As situações/casos de sofrimento mental (depressão e esquizofrenia).

Percebe-se que os profissionais integrantes das equipes ampliadas fazem uma diferenciação, apontam as demandas e necessidades que mais chegam da comunidade relacionando-as ao seu campo de atuação profissional:

- Equipe de Saúde Bucal: dores, extrações e restaurações;

- Equipe de Saúde Mental: transtornos de humor; situações de crise e surtos psicóticos relacionado ao uso de substâncias como álcool e drogas junto; uso abusivo de álcool; sofrimentos por situações de violência doméstica;

- Equipe de Reabilitação: dores; casos ortopédicos, reumatológicos e neurológicos; bebês em situação de risco; e pessoas em diferentes faixas etárias com incapacidade. 
Todos os profissionais compreendem que o serviço de saúde acolhe bem as demandas e necessidades colocadas pela comunidade. Para eles, o acolhimento só não é realizado quando há a interferência, por exemplo, de mudanças estruturais e políticas.

as demandas de pronto-atendimento acredito que atenda melhor que o $\mathrm{AMA}^{24}(\ldots)$. O PSF cumpre este papel melhor, porque o acesso é mais fácil. A equipe está mais próxima do usuário, não só em termos de proximidade do local de moradia, mas de escuta mesmo. Hoje você vê que muitas demandas que a equipe tenta encaminhar para o AMA são devolvidas, o que gera muito estresse para os funcionários e acaba dificultando o trabalho nas ações necessárias (Aline, fonoaudióloga).

O serviço tenta acolher, só que no momento por questões políticas, existe uma ordem de não acolher muitas coisas. É ordem de cima, da prefeitura. Então, a gente obedece e manda para o AMA. Isto é um pouco sofrido. (...) há coisas que você tem que fazer aqui por mais que exista o AMA. (...) ele é importante, tem o seu lugar. Mas se eu tenho vínculo com aquela pessoa, conheço muito mais do que a patologia, então tem que acolher aqui mesmo (Luana, terapeuta ocupacional).

De modo geral, os profissionais da USF não marcam prontamente os temas médicosociais: violência, uso abusivo de álcool e drogas, e, sofrimento mental ao serem questionados sobre as demandas e necessidades da comunidade que mais aparecem no serviço de saúde.

Contudo, quando esses temas são problematizados diretamente, observam-se as percepções dos profissionais se alternam quanto à freqüência com que se deparam no cotidiano de trabalho sem negar suas existências.

Os ACS são unânimes ao afirmar que se deparam com demandas e necessidades relacionadas à violência, uso abusivo de álcool e drogas, e, sofrimento mental. Relatam que grande parte destas não chega de modo espontâneo, são percebidas em visitas domiciliares ou diálogos informais na rua por eles ou no decorrer dos atendimentos e consultas agendadas por outros profissionais, principalmente, pelo médico ou enfermeira da ESF.

\footnotetext{
${ }^{24}$ A Assistência Médica Ambulatorial - AMA foi implantada em 2005 a partir de uma intensa discussão sobre a mudança de modelo de atenção básica de saúde no município de São Paulo. Esta é gerida pela SMS-SP e parceiros públicos e privados; sendo que prioriza o atendimento dos pacientes portadores de patologias de baixa e média complexidade nas áreas de clínica médica, pediatria e cirurgia geral ou ginecologia. Além disso, tem como objetivo ampliar o acesso de pacientes que necessitam de atendimento imediato, racionalizar, organizar e estabelecer o fluxo de pacientes para UBS, Ambulatórios de Especialidades e Hospitais (PREFEITURA MUNICIPAL DE SÃO PAULO, 2007, 2008).
} 
Outros profissionais consideram que os temas são relevantes no setor Saúde, mas não os reconhecem como presentes no cotidiano do seu trabalho.

Considera-se que a efetiva relação entre o serviço de saúde e a comunidade vai ao encontro de estudos que valorizam a APS como estratégia para visualizar demandas e necessidades sutis, porém concretas, que muitas vezes estão escondidas no território.

Somadas essas idéias, sugere-se que os profissionais de saúde que possuem maior aproximação e integração com os usuários percebam e reconheçam mais e melhor as demandas e necessidades médico-sociais da comunidade.

Segue-se a problematização e a compreensão das três temáticas médico-sociais (violência, uso abusivo de álcool e drogas, e, sofrimento mental) relacionadas às demandas e necessidades da comunidade alvo da USF enfocada por este estudo.

Para efeito de análise, a polaridade ${ }^{25}$ formada pelas percepções dos profissionais moradores do território (profissionais técnicos e com nível superior) e dos que não são moradores (ACS) será retomada.

\subsubsection{VIOLÊNCIA}

teve um menininho que a mãe queimou a mão, porque ele mentiu. Ela queimou a mão com a colher quente. Colocou a colher no fogo, 'catou' a mão dele e queimou como castigo (Camila, auxiliar de enfermagem).

Uma das ACS ouviu a criança da vizinha chorando e gritando para o pai parar. Ouviu várias vezes. Viu que a mãe da criança estava do lado de fora da casa. Todos os dias a mãe saía no mesmo horário e deixava as filhas sozinhas com o pai. A mãe sabia o que ele fazia, mas não podia fazer nada. Então, não ficava em casa para as outras pessoas não saberem que ela deixava (Relato de ACS sobre abuso sexual de crianças reproduzido no Relatório do Grupo Focal).

apanha, apanha, apanha e diz que ama e vai voltar. Há casos que o marido corta a mulher. Já peguei uma aqui que o marido cortou a mama (...). Depois de muito tempo, que já cicatrizou (...): “Ah, doutora! Meu marido é muito violento, me bate, me espanca, mas eu não posso contar para ninguém, porque ele me ameaça. Se eu contar para alguém ele vai fazer maldade comigo (...).” Aí puxa a blusa, você olha e vê que está cortado. Há outras que os maridos são altamente ciumentos e não as deixam sair de casa, nem para vir na unidade (...). Outras vêm roxas (Marta, médica).

\footnotetext{
${ }^{25}$ Inicialmente discutida no item 6.1.
} 
Inicialmente a violência é percebida pelos profissionais de saúde entrevistados a partir das características do próprio território de atuação. A região onde se localiza a USF é tida pelo senso comum e pelos dados ${ }^{26}$ como uma das mais violentas do município de São Paulo por associar tráfico de drogas, esconderijo de fugitivos e altos índices de homicídios.

Somente um profissional, que atua há aproximadamente 07 anos na região, aponta para existência de mitos sobre a violência e criminalidade na comunidade. Concorda que ocorreram tiroteios, mortes na época dos ataques do PCC $^{27}$, até situações em que se colocou em risco; porém, estes foram episódios pontuais e não interferiram na execução e continuidade do seu trabalho.

Os demais profissionais contradizem esta opinião e acreditam que a influência da violência na comunidade nunca deixou de existir. Até pode-se observar sua interferência na relação do serviço de saúde com a comunidade, pois alguns profissionais evitam se aproximar dos usuários e o ‘saber demais’ para não desencadear situações de risco para eles.

procuro não me aprofundar tanto, (...). Tem gente que vai atrás, porque quer saber. Eu não. (...) é até a questão que falo da violência (...), se não me atinge é porque procuro não ficar sabendo do que acontece. Senão a gente não vive, não consegue nem trabalhar em paz. Por isso que falo que eu não sei muito dos casos a fundo. (...), porque quanto menos você sabe, menos envolvida você está (Camila, auxiliar de enfermagem).

A violência é compreendida pelos profissionais de diversas formas: um problema amplo; tudo que agride o outro, seja por palavras e ações; tudo que limita a ação individual; coação; impedimento de se expor, dentre outras. Diferentemente os ACS, que são moradores da comunidade, a compreendem a partir de suas experiências e vivências, limitando o conceito para o que os atingem diretamente.

Este último grupo cita, como exemplo, o que é violência para eles: ver vizinhos que passam fome e não têm como conseguir alimento; trancar os filhos em casa e não deixá-los

\footnotetext{
${ }^{26}$ A região é considerada um dos 'bolsões de pobreza' do município de São Paulo. Para ler mais sobre esta informação veja o Capítulo 5, item 5.1.

27 Primeiro Comando da Capital - PCC é uma organização criminosa comandada por presos e foragidos principalmente no Estado de São Paulo.
} 
brincar na rua pelo medo que se envolvam com drogas; não ter o direito de ir e vir por causa dos limites de horários impostos pelo tráfico de drogas; conviver com um grupo de adolescentes e jovens fumando maconha na porta de sua casa; não conseguir dormir pelo barulho das festas patrocinadas pelo tráfico de drogas em frente de sua casa.

Sobre o porquê da ocorrência da violência, alguns profissionais consideram que esta se deve aos fatores sociais. Acreditam que ela está presente em todo lugar e citam os problemas de ordem financeira e de estrutura familiar como os que mais geram e desencadeiam as situações de violência.

Um ponto levantado por uma ACS é o comodismo das pessoas em relação à violência.

Eu acredito que aqui [a origem da violência no território] (...) é as pessoas fazerem 'vistas grossas' para o que acontece. Aceitarem e deixarem por isso mesmo. Mas o povo já se acomodou. Para eles está tudo bem (Marcela, ACS).

Outra ACS mencionou que as escolhas pessoais podem conduzir uma pessoa para a violência. Relata que por ter crescido na favela recebeu convites para se envolver com 'coisas ilegais', no entanto, decidiu por não seguir este caminho. Sente-se bem por ter casado com um homem honesto, estar empregada e ter conquistado um modo digno de viver diferentemente de muitos colegas de infância e adolescência.

De acordo com alguns profissionais, as demandas e necessidades da comunidade relacionadas à violência aparecem pouco e de modo enviesado na USF.

Violência (...) mesmo são poucos. Neste tempo que estou aqui (...), dois ou três casos que nós vimos (...), um ou outro caso isolado (Amanda, médica).

Eu não lembro do que aconteceu. (...) sei que entrou no Conselho Tutelar. Depois que terminou o tratamento [odontológico] fiquei meio à parte sobre o que aconteceu. Não foi só nós da [Saúde Bucal] não, foi a equipe em geral também (César, cirurgião-dentista, ao lembrar de uma situação de abuso sexual de criança).

sabe que existe, mas não pode falar que tem. Senão a gente está em risco. Aqui é aquela coisa, você vê de olhos fechados. Isto [situações de violência] todo dia aparece, mas você vê e não faz nada. (...). Você dá um atendimento, se precisar, você encaminha (...). Mas você não pode ir além da conversa (Roberta, enfermeira). 
Esta percepção se difere daqueles que trabalham e moram na comunidade. Os relatos dos ACS são repletos de detalhes e dão ênfase às diferentes situações/casos de violência presentes em seu cotidiano: violência relacionada ao uso de drogas e ao tráfico; violência familiar (pais que espancam crianças; mulheres que apanham do marido; filho que bate em pai idoso); violência sexual (abuso sexual; estupro cometido por pessoa de fora da comunidade).

Embora os profissionais tenham relatado em um primeiro momento que são poucas as demandas e necessidades relacionadas à violência que chegam à USF, quando questionados sobre situações/casos que mais lhe chamaram atenção revelam um repertório vasto demonstrando o número expressivo, algumas proximidades e tentativas de intervenções. As situações/casos se repetem nos relatos em termos de violência contra mulheres, crianças e jovens; e, em menor número, contra idosos e doentes mentais.

Apreende-se que essas situações/casos chegam à USF problematizadas, em sua maioria, pelos ACS. Eles pontuam que as discutem em reuniões de ESF, mesmo que não haja posicionamentos da equipe para intervir ou procurar meios para efetivar alguma ação.

As agentes comunitárias sabem de tudo. (...). Por elas morarem na comunidade e todas há anos. A grande maioria nasceu aqui ou veio para cá quando eram crianças. Então, elas conhecem um por um, vida íntima, vida pessoal, vida de tudo. Elas trazem: "Olha, naquela família aconteceu isso, isso e isso." Aí elas falam: "Doutora, não vejo solução, porque não tem como fazer. Não dá”. Há [casos de] violência doméstica, que não deixam entrarem. Quando a mulher apanha muito do marido, dos filhos, eles não deixam o agente entrar (Marta, médica).

Essa potencialidade do ACS em elucidar as demandas e necessidades da comunidade ao serviço de saúde, corrobora com os estudos realizados por Malfitano e Lopes (2003); Crevelim e Peduzzi (2005); Cohn, Nakamura e Cohn (2005); e, Lopes et al. (2007).

Entretanto, outros profissionais não moradores da comunidade contrapõem essa idéia acreditando que os ACS aceitam a violência por naturalizá-la no meio em que vivem ocasionando até mesmo a diminuição de sua problematização no serviço de saúde. 
agressões contra mulheres, brigas de marido e mulher, crianças em situação de violência (...) têm bastante. Agora mudou, não chega tanto. Mas sabe por que mudou? Isso é muito complicado de falar, as agentes comunitárias acham isso tudo normal (...). (...) lembro de uma história que quando elas contaram, fiquei indignada. (...) o pessoal da boca, os chefões, (...) eles 'pegam' a menina mais bonita da comunidade e os pais têm que autorizar. É meio um harém para o dono da boca. Ele pode ter relações sexuais com ela. (...). Quando as agentes me contaram isto, me contaram como se fosse a coisa mais normal do mundo (...). Tentei discutir, não dava, porque é uma coisa que está introjetada mesmo (Luana, terapeuta ocupacional).

As situações/casos consideradas 'mais gritantes' pelos profissionais, por exemplo, a

violência, os maus tratos e os descasos relacionados às crianças, que estão implicados os familiares, bem como outros atores e equipamentos sociais, escola, Conselho Tutelar e até mesmo integrantes da comunidade são repetidos nos relatos por diferentes profissionais.

Muitas vezes chega para mim casos (...), por demanda da escola ou da creche. (...). Então, a gente vai atrás. Ou (...) pelo Conselho Tutelar. (...) tenho um caso de uma criança que sofreu queimaduras no começo do ano passado, é a segunda vez, brincando com uma outra criança de jogar fogo um no outro. (...) a criança não estava indo para escola, estava sempre mal cuidada, (...). (...) [o Conselho Tutelar] mandou uma carta pedindo um relatório de acompanhamento e perguntando se ele estava indo ao especialista. (...) desde a última vez que eu tinha ido a casa dele, a gente fez um encaminhamento para ele passar com o médico cirurgião plástico, e a mãe ainda não o tinha levado. (...) a enfermeira e a psicóloga sentaram com a mãe (...). O menino teve que fazer enxerto de pele. A perna toda queimada, a barriga, o braço, teve uma queimadura importantíssima mesmo. (...). No dia que eu fui vê-los, a mãe estava lavando o menino com sabão de pedra. A comida toda estragada em cima do fogão. Ela punha a mesma faixa no curativo, não lavava, não limpava, era complicado. A gente tentou fazer este resgate e até conseguiu que ele viesse na unidade mais uma, duas vezes. Ele sumiu de novo. E a gente tenta de novo (Amanda, médica).

Entende-se que essas situações/casos conseguem ser vistas de modo multiprofissional e intersetorial a partir do momento que abrange outros atores e equipamentos para além do universo da USF.

Diante de situações/casos tão 'gritantes' quanto a que foi citada e que se mostra com 'complicadores', principalmente, por envolverem pessoas ligadas ao tráfico de drogas e à criminalidade, percebe-se uma estagnação e justificativas reiteradas de que não há o que se fazer. 
No grupo focal, uma das ACS relatou aos sussurros, por medo de ameaças, que foi impedida de realizar a visita mensal em uma casa vizinha, porque como ela mesma pontua lá predomina a sentença: ‘em briga de marido e mulher, ninguém mete a colher’, dado que quem agride a mulher é um dos traficantes maiorais da comunidade.

Os profissionais do serviço de saúde diante da violência contra mulheres recorrem ora ao julgamento moral, ora a medicalização. Há uma culpabilização das mulheres por permanecerem nessa 'relação doentia’. D’Oliveira (2000), Schraiber et al. (2002, 2007) e Kiss (2004) problematizam este tema em seus trabalhos.

Ressalta-se dos relatos a existência de regras e leis da comunidade que impossibilitam o aparecimento das situações/casos de violência. Não falar por medo de represálias, aceitar a situação em que estão submetidos e ter vergonha diante do profissional de saúde são atitudes dos usuários que sofrem violências apontadas pelos profissionais.

No acolhimento não chega, mas chega às vezes na sala de curativo. (...) a gente ficou uma semana cuidando de uma perna de uma moça. Aí eu olhava para aquele ferimento (...) e não condizia o ferimento com o que ela está falando. (...). Aí chegou um dia com outra história, ela contou e não me convenceu. (...). [Depois de uns dias] ela falou: "Eu posso te contar de verdade? Posso te falar mesmo o que aconteceu? É que eu fui dar uma facada no meu marido, ele segurou e passou na minha perna” (Simone, enfermeira).

algumas situações de violência até de colegas (...) e você orienta: "Olha, existe delegacia da mulher, tem um monte de telefone." "Ah não, não adianta não. Não precisa.” Então, as pessoas agem normal em apanhar, em ficar quieta (...). (...) no cotidiano dos atendimentos, também ouço muitas situações de violência. (...) na grande maioria não é nem reclamar, nem pedir ajuda, é meio que um desabafo. E quando você tenta se aproximar, oferecer alguma proposta, aí você tem: “Ah, não. Assim está bom”. Raras vezes as pessoas querem efetivamente correr atrás (Luana, terapeuta ocupacional).

Agora [violência] doméstica, de marido e mulher, sempre tem. Só que eles não chegam muito aqui, acho que até eles têm vergonha, apesar de que a gente conhece bem a família (Camila, auxiliar de enfermagem).

Os ACS também confirmam que os usuários tentam esconder os casos/situações de violência deles. 
Poucas mulheres que sofrem violência pedem ajuda e quando a solicitam querem apenas uma ‘escuta’ do médico, enfermeira ou psicóloga para si. A maioria das mulheres não solicita ajuda para o marido, nem aceitam denunciá-lo.

Outra forma de violência escondida é o abuso sexual de crianças. Sabe-se que graves punições são dadas pelos componentes da organização do tráfico, que 'cuidam' da comunidade, aos envolvidos e familiares coniventes.

Os donos do pedaço se vêem crianças na rua depois das dez horas da noite, eles fazem colocar para dentro de casa. Se (...) chegar ao ouvido deles que alguém está espancando: "Olha fulano está fazendo isso, isso e isso com ciclano.” Eles tomam providência. Nós não podemos tomar providência, mas eles podem (Marta, médica).

Os profissionais de saúde ao serem questionados se consideram a violência aceitável, muitos respondem que não. Só que diante do território onde atuam as percepções mudam:

enquanto eu estou aqui, é que nem a gente fala, a gente tem que fechar um pouco os olhos. Se for bater de frente, a gente não fica aqui, não fica mesmo. Eu tenho que acabar sendo conivente com algumas coisas. E é assim, fecho os olhos. Se eu não vir é melhor (Amanda, médica).

Todos os ACS em grupo focal afirmam que não aceitam a violência, mas são obrigados a aceitá-la, já que não podem fazer nada para combatê-la em seu território de moradia e trabalho. Revelam que não concordam com o que vêem diariamente, mas sentem-se impotentes para mudar a realidade do território.

As contradições apontadas pelas percepções dos profissionais de saúde diante das demandas e necessidades relacionadas à violência, revelam o quanto o grupo é heterogêneo e desconhecedor de seus 'pares'. Logo, as relações em equipe multiprofissional vistas como coesas e integradas, em um terreno repleto de complexidades se mostram vulneráveis aos distanciamentos no decorrer do cotidiano de práticas do PSF.

Vê-se, portanto, uma 'rede esgarçada' em determinados momentos: os profissionais de saúde, não moradores da comunidade, encaram somente a parte comunitária dos ACS e estes últimos reproduzem somente as atitudes técnicas aprendidas no trabalho em saúde que os 
distanciam dos usuários do serviço de saúde como se eles não fossem pertencentes à mesma comunidade. Relações não estáticas, mas que podem ocasionar desvios da missão colocada pelo PSF. Outros pesquisadores estudam essas relações como Cohn, Nakamura e Cohn (2005).

\subsubsection{USO ABUSIVO DE ÁLCOOL E DROGAS}

Tem um caso de uma paciente que ela entrou numa depressão tão grande, que começou a ser usuária. Um dia ela me pediu: "Eu quero fazer exame de HIV, hepatite, etc.” (...). "Nossa, mas por quê?” Aí ela me contou que era usuária de farinha, só que injetável. (...). Eu nunca ouvi falar isso na minha vida, mas ela disse que diluía em pinga. Não me pergunte como, mas ela disse (...): “Isso mesmo, doutora, eu diluía em pinga” (Marta, médica).

uma mulher que usava muito álcool e isto era apenas uma das questões. Ela tinha uma filha de 10 anos, portadora do HIV, e viviam numa situação de muita miséria. Morava num barraco horroroso, ela, esta filha (...) e o filho adolescente. $\mathrm{O}$ adolescente (...) usava maconha, estava envolvido com o tráfico (...). (...) ela recolhia papelão, bebia muito e não conseguia exercer o papel de cuidadora mais efetiva da menina, que precisava tomar coquetel e ser levada ao serviço de referência. Ela acabava perdendo as consultas, (...). A menina tinha momentos de adoecer, de se internar e veio efetivamente a falecer (Rebeca, psicóloga).

Ao contrário do que emerge das falas iniciais sobre a violência, nas quais ela é paulatinamente discutida como tema que aparece no cotidiano da USF, o uso abusivo de álcool e drogas tem presença unânime e constante nos relatos de todos os profissionais de saúde.

Para os profissionais, alguns usuários que usam abusivamente do álcool chegam à USF por demanda espontânea. Esta se constitui por homens adultos, na faixa etária de 30 a 50 anos, que solicitam ajuda para parar de beber. Nesta situação, observa-se que a relação profissional-usuário é prejudicada pelo abandono rápido do tratamento pelos usuários e pelas ausências de aporte técnico dos profissionais e de equipamentos para referência e contrareferência.

Outras situações/casos são percebidas no cotidiano. São usuários que freqüentam a USF, mas não necessariamente fazem algum tipo de tratamento. Um dado marcado pelos profissionais é o número expressivo de mulheres adultas que fazem uso abusivo de álcool. 
ela chegou aqui esses dias. Acho que ela bebeu tanto, tanto, que está com uma pancreatite. Ela foi internada e tem três crianças pequenas. Ninguém queria ficar com os filhos dela. (...). Você imagina a mãe internada e [os conselheiros tutelares] levaram as crianças, quer dizer, ela não vai parar de beber nunca (Marta, médica).

Uma questão problematizada por todos os profissionais que desfavorece as ações preventivas ao uso abusivo de álcool é a quantidade de bares e botecos existentes no território.

Eu tenho a área dos alcoólatras, numa única rua, com mais de treze bares (Simone, enfermeira).

Se você descer numa viela, você vai ver um botequinho, um botequinho, um botequinho. Olhei por curiosidade e falei: "Quanto custa uma dose de pinga?” Na época custavam 0,25 centavos e um leite custava 1,20 (...). O morador daqui não tem lazer. Então, ele vai e toma uma dose no bar. (...). E aí o que acontece, deixar marcar uma pinguinha, ele deixa. O leite, ele não deixa (César, cirurgião-dentista).

É o que mais tem aqui. Mais que droga, violência. Porque o álcool é barato, alimenta. A oferta é muito grande, não é proibida e tem muita procura. É a lei da oferta e da procura (Marisa, ACS).

Sete horas da manhã, quando a gente está vindo para cá [para a USF], tem um homem dono de um boteco perto da escola, que mesmo quando está dormindo, o povo está na porta dele. Ele toda hora está enchendo os copos e dando cachaça e vinho para as pessoas. O povo bate na porta da casa dele e ele já sai com a garrafa na mão (Corina, ACS).

Os ACS ressaltam que muitos usuários deixam de tomar seus remédios para fazer uso de bebida alcoólica diante das facilidades em acessar os bares e botecos. Assim, concluem que a única coisa que podem fazer para a diminuição do uso abusivo de álcool é orientá-los.

A maioria dos profissionais de saúde acredita que as pessoas fazem uso do álcool para fugir da realidade e dos problemas; diminuir as tristezas diante das faltas de expectativas; alimentar-se; agredir seu próprio corpo; ter coragem de falar o que pensa; esquecer-se de algo que fez no passado; e, por prazer.

Eles não têm auto-estima, perspectiva de vida. Muitos bebem para passar a fome. Tem pai de família que bebe porque não tem o que comer. Como é que ele vai sobreviver sem comida? (...). A fome dele diminui a partir do momento que ele bebe (...) pinga, conhaque, que é trinta, quarenta, cinqüenta centavos a dose. Então, dá para tomar quantas doses por dia com dez reais? (Marta, médica).

tive um paciente no hospital (...), que deu todo o estudo para esposa se formar. Depois, ela se separou dele e por este motivo ele se entregou ao 
álcool (...). (...) ele havia sofrido um acidente por uso abusivo e (...) teve um monte de problemas. Um deles era a fratura de mandíbula (...). Ele ficava contido no hospital, porque tinha abstinência (César, cirurgião-dentista).

tem dia que Dona Maria vem firme: "Não, eu não vou beber mais.” (...) E fica firme dois, três meses. Mas vai ver a história de vida desta pessoa, ela já perdeu um filho assassinado. As histórias do pessoal aqui, que são alcoolistas, são muito tristes. É um passado de violência familiar, morte na família por causa de droga, morte na mão de policiais (Raquel, auxiliar de enfermagem).

você pega uma pessoa que é mais tímida, quer dizer, a pessoa usou o álcool e aí se desinibiu, gostou de tomar a bebida. Cada vez que ela vai tomando, ela vai se desinibindo (...). Só que quando ela desinibe, não desinibe só o que tem a ver com a timidez, desinibe a agressividade, desinibe outras coisas que estão ali. (...) pode-se sentir culpada, aquilo retorna e aí bebe porque se sente culpada, enfim, os fatores são múltiplos (Romeu, psiquiatra).

Contudo, uma profissional considera que as justificativas para o uso abusivo de álcool às vezes se tornam exageradas:

a maioria é falta de vergonha mesmo. (...) as pessoas bebem por falta disso, por falta daquilo, falta daquilo outro (...). Você não precisa beber para superar os seus problemas, tem tanta coisa que você pode fazer. Aqui eles não fazem nada, a bebida é uma forma de desabafo. (...) se briga com a mulher, vai para o boteco beber, porque brigou com a mulher. Se for mandado embora do emprego, vai beber, porque foi mandado embora do emprego. Se for fazer alguma coisa, vai beber, porque é aniversário do fulano. Tudo é motivo de beber (Marta, médica).

No grupo focal, uma ACS reitera ao dizer que não existe necessariamente um motivo a priori para beber. Para ela, muitas pessoas começam a fazer uso de bebida alcoólica sem motivos e assim vão consumindo cada vez mais até ficarem dependentes.

Para os ACS, o álcool afeta diretamente as dinâmicas familiares. Citam exemplos de pessoas que fazem o uso diário e não apenas o pouco aceitável nos finais de semana e as que necessitam da bebida para conseguir falar o que pensam acarretando mágoas aos familiares.

Neste mesmo sentido, destaca-se o depoimento de uma profissional que ilustra as dificuldades familiares diante do alcoolismo:

Tenho casos na família, (...) já perdi um irmão, vai fazer um ano por causa do álcool, e tem um outro que está com 34 anos. (...) este [último] já perdeu a família, mulheres e filhos. Dois casamentos destruídos por causa do alcoolismo. (...). Parou de beber um tempo, porque viu que o outro [irmão] morreu (...). Mas voltou a beber. (...). Isso com o pai, com a mãe, com todo mundo aconselhando. Agora ele teve um AVC. (...) meu pai, minha mãe 
nunca beberam. (...). Mas tinha um avô que era terrível, bebeu até morrer, só que os meus irmãos não conviveram com ele. (...) curtir bêbado não dá. (...) meu avô era muito estúpido, muito difícil (...). A minha mãe teve que fugir de casa muito nova. Ela saiu de casa e foi casar aos 15 anos, porque o meu avô era demais (Raquel, auxiliar de enfermagem).

Já problematizar o uso abusivo de drogas na condução das entrevistas e grupos focais se mostrou bastante provocativo e, ao mesmo tempo, denunciante das impotências e fragilidades dos profissionais de saúde. Todos marcam a necessidade urgente de se olhar para o tema, porém se vêem muitas vezes de 'mãos atadas'.

Tem [uso abusivo de drogas], nossa como tem. Mas a gente não pode falar disso. Por quê? Porque a gente está no meio da boca, entendeu? (...). Você vai mexer com isso, vai mexer com quem? Com o chefe. E aí depois, como você anda na comunidade? Você não anda. Então, a gente sabe que tem, mas não se discute casos extremos. (...). Sabemos que existem jovens traficando (...) e usando, mas não se comenta muito não (Luana, terapeuta ocupacional).

Os ACS relatam que as mães são as que mais procuram ajuda para os filhos em situação de uso abusivo de drogas e diante delas não sabem o que fazer e nem para onde encaminhar (Relatório do Grupo Focal).

Uma ACS questiona a não existência de clínicas para o tratamento de pessoas que fazem uso abusivo de drogas. Ela afirma que quando sabe de algum grupo, clínica ou lugar fora da comunidade para tratamento indica para as famílias, mas considera muito pouco frente à oferta constante de drogas próxima às residências das pessoas.

Outra ACS explica ao grupo que as clínicas de internação se extinguiram devido à atual proposta da família cuidar do familiar que faz uso abusivo de drogas com objetivo de não abandoná-lo em instituições fechadas.

Diante disso, foi aberto um debate durante o grupo focal sobre o que fazer diante das drogas e os melhores locais para o tratamento daqueles que necessitam de ajuda.

Os ACS optam pela internação como a ajuda possível para as pessoas em uso abusivo e dependência de drogas. Justificam esta escolha pelas facilidades de acesso às drogas no território, ou seja, acreditam que se a pessoa continuar morando com a família, não conseguirá se livrar do vício. 
Esses profissionais afastam qualquer possibilidade de intervenções resolutivas a partir da USF em seus depoimentos. Observa-se que os ACS têm confusões e dificuldades em delimitar o seu papel e o da USF diante das demandas e necessidades da comunidade relacionadas ao uso abusivo de drogas.

A organização do tráfico de drogas novamente foi apontada por todos os profissionais como bem estruturada e com grande interferência na comunidade.

A comunidade respeita o traficante, porque de alguma forma ele traz alguma norma, segurança ali (Romeu, psiquiatra).

Traficante aqui dá presentes de natal, cestas básicas, presentes para as crianças, (...). "Quem não mexe comigo e quem precisa, eu ajudo". Porque eles [os usuários] ficam coniventes com isso. Às vezes, a gente fala: “A maior proteção é do traficante, não é da polícia” (Amanda, médica).

Os ACS compreendem que a organização do tráfico é uma possibilidade de trabalho para as crianças que vivem na comunidade. Os rapazes mais velhos influenciam os meninos na inserção do tráfico ofertando garantias de dinheiro fácil, rápido e poder para conquistar desde um tênis até 'status' na comunidade. Além disso, afirmam que muitos pais são coniventes, porque também se utilizam do dinheiro obtido e os 'benefícios' trazidos pelo tráfico através de seus filhos.

Importante compartilhar que houve uma reação diferenciada no grupo focal dos ACS quando estes debateram o tema. A agitação para exporem suas idéias suscitou relatos com sentimentos de medo, impotência e raiva. As ACS que possuem filhos pequenos demonstraram ter muito medo de que estes se envolvam futuramente com o universo das drogas. Ficam indignadas com as festas promovidas pelo tráfico de drogas na comunidade, as quais estimulam a presença de muitos jovens já que eles não têm outro tipo de lazer.

Outros profissionais também exemplificam essas relações que ‘chocam’ por serem tão próximas do cotidiano da comunidade e até mesmo do serviço de saúde:

É muito complicado criar um filho aqui dentro porque a droga é muito próxima deles (...). Tem crianças com sete, oito anos, que querem trabalhar na boca. Para eles é legal, vão ganhar dinheiro. Eles querem trabalhar na 
boca que nem o menino que morreu aqui. Disseram que ele fez aviãozinho a noite inteirinha. Ficava vendendo as drogas para os 'caras'. E o que ele ganhava? Droga para ele consumir. Deu uma overdose. Cinco horas da manhã já trouxeram ele para cá morto (Raquel, auxiliar de enfermagem).

Segundo os profissionais, há muitas pessoas, em diferentes faixas etárias, que fazem o uso abusivo de drogas. Estas não freqüentam o serviço de saúde a não ser quando têm outras demandas e necessidades de saúde que requerem atuações rápidas e pontuais (por exemplo, a inalação).

Tem bastante caso, mas também não vem. Essa população que usa muita droga não vem ao posto, um ou dois só vêm quando estão passando mal. (...). Passando mal porque está muito ruim de uma tosse, por outras coisas. (...) parece que tem alguma coisa entre eles, alguma lei que não pode vir para cá. Uma vez um rapazinho estava passando mal e uma moça virou para ele: "Você sabe que não pode ir aí.” Não sei se é alguma coisa, um código. Por ser perto, às vezes 'pega' alguma coisa para eles (Andréa, auxiliar de enfermagem).

Os ACS acreditam que por serem profissionais de saúde conseguem perceber e sentir o uso abusivo de drogas de seus usuários quando este ainda está no início, diferentemente dos demais moradores da comunidade que só percebem a situação quando está bem avançada. Entretanto, não conseguem pensar em ações preventivas e/ou redutoras de danos por eles e pela USF.

\footnotetext{
"Cansei de vir aqui na boca duas, três horas da manhã buscar esse menino." Falou que cansou de vir, fez de tudo. As mães perdem muito fácil para as drogas aqui dentro. Tem criança, adolescente que quando vim para cá ele estava com dez anos. Hoje ele está com catorze e a gente já vê que está declinando (Raquel, auxiliar de enfermagem).
}

Destacam-se os relatos dos profissionais que marcam a impotência e evidenciam a repetição de uma triste cena: a USF só 'acolhe' os adolescentes e jovens que usam abusivamente de drogas quando estes chegam em overdose, sendo que neste momento pouco pode ser feito.

As percepções dos profissionais de saúde sobre o porquê de uma pessoa fazer uso abusivo de drogas lembram aquelas percepções apresentadas diante do uso abusivo de álcool, ou seja, as que se remetem à fuga, à desesperança, ao modo de esquecer problemas e/ou 
sofrimentos. Em um contexto de extrema miséria, a droga também é uma alternativa para diminuir a fome.

tenho adolescentes com bastante problema de carência nutricional, falta alimento e tem a oferta abundante do mundo das drogas. A área em que atuo da USF é uma das mais violentas daqui (Simone, enfermeira).

Os ACS evidenciam outras percepções sobre o porquê do uso abusivo de drogas: a influência pelas relações de amizades, a empolgação, a curiosidade, a busca por uma 'válvula de escape' diante dos conflitos familiares; situações que comumente perpassam a adolescência.

A ACS considerou que a influência dos amigos é o fator preponderante no envolvimento com as drogas na comunidade. Baseada em sua experiência pessoal, relatou que o irmão trocou o álcool pelo crack, após construir uma amizade com um rapaz que era usuário de drogas (Relatório do Grupo Focal).

Nos adolescentes é curiosidade, é o experimentar, é conhecer, é o descobrir. "Ah, quando eu uso, eu estou bem; aí, eu vou usando outro, eu vou oferecendo aos outros”. Aí começa, principalmente a cocaína e o crack que em três ou quatro vezes juntos tem-se uma dependência química (Amanda, médica).

Tem uma família que já perdeu os filhos para o Conselho Tutelar por causa do alcoolismo (...). Os dois meninos ficavam até altas horas da madrugada fazendo 'aviãozinho' para o pessoal que queria droga. As pessoas davam dinheiro para eles buscarem a droga. Os pais ficavam em casa e bebiam de dormir, de capotar, e estas crianças sem ter o que comer. $\mathrm{O}$ que elas poderiam fazer? (Raquel, auxiliar de enfermagem).

Finaliza-se esta análise, ao se retomar a discussão sobre aceitar ou não o uso abusivo de álcool e drogas pelos profissionais de saúde.

Os profissionais não moradores da comunidade polarizam suas opiniões: ora se consideram um pouco mais tolerantes compreendendo que o uso de álcool e drogas faz parte das necessidades do ser humano, ora repudiam totalmente por ele se tornar abusivo e ocasionar problemas físicos, mentais e até mesmo sociais naqueles que o utilizam. Já os ACS foram unânimes em dizer que não aceitam o uso abusivo de álcool, nem de drogas.

Sobre estes dados, vale salientar que: 
- Alguns profissionais não moradores se mostram dissociados ao expressarem opiniões diferentes quando questionados sobre suas concepções pessoais e profissionais.

- O posicionamento unânime dos ACS provoca estranhamentos e retoma a hipótese de que estes recuperam as concepções normativas e morais da sociedade.

- O não aceitar por todos os ACS não condiz com a vivência cotidiana, percebida nas entrelinhas dos relatos, quando alguns demonstram o prazer em fazer uso de bebidas alcoólicas em momentos familiares, festas e/ou finais de semana. Nem significa combater o uso de álcool e drogas, porque nos relatos pode ser apreendido que a 'convivência cotidiana' os tornam naturalizados, enfim, integrados ao território e à comunidade.

As demandas e necessidades relacionadas ao uso abusivo de álcool e drogas perpassam compreensões de cunho normativo, medicalizado e relativizado diante das complexidades nelas implicadas, desse modo as ações e intervenções da USF são afastadas e as sensações de impotências e frustrações somente são denunciadas quando problematizadas.

Um dado emblemático é que as ações intersetoriais, que poderiam ser uma estratégia para lidar com essas demandas e necessidades da comunidade, não foram citadas pelos profissionais de saúde.

\subsubsection{SOFRIMENTO MENTAL}

uma vez, uma moça tomou um monte de remédio. Não sei se foi ela que tomou ou se alguém deu. Chamaram para ir à casa para ver como ela estava. Cheguei lá e fazia mais (...) de 24 horas que dormia. (...). A gente orientou que tinha que levar para o hospital e o suposto marido (...) não queria levar (Raquel, auxiliar de enfermagem).

um paciente jovem. (...) ele estava numa depressão profunda, não saía de casa, não tomava banho, não comia. Entramos com uma medicação e ele teve uma virada maníaca. Então, ele veio cheio de colares de prata, todo arrumado e agitado. (...). Ele é uma pessoa que vem no posto para fazer social. Então, ele 'xaveca' todo mundo, briga se alguém quer passar na frente ou de repente começa a discutir. (...). Complicado o manejo de medicação, às vezes ele toma (Amanda, médica).

é uma paciente esquizofrênica. (...) por mais que você trate, ela não tem cura. (...). Mas o que ela faz com a família é uma coisa de louco. Ela fica falando: "Ele me estuprou, ele me fez um filho." E ela fica apontando para quem? Para o pai. O pai chora. "Nem encosta em mim, porque você me estuprou. 
Você fez um filho e me fez tirar.” E não é verdade. (...). Os pais sempre cuidaram muito bem dela. Ela bate na mãe, briga, não aceita tomar remédio, grita, chora. Ela se tranca dentro do banheiro e deixa o chuveiro ligado por 3, 4 horas (...). Ela toma café, joga café fora, tira a roupa, sai na rua, grita, (...). Ali eu vejo o sofrimento da família (Marta, médica).

Nos relatos dos profissionais de saúde em geral percebe-se que a saúde mental tem lugar diferenciado na relação ‘serviço e comunidade’ pelo fato de a compreenderem enquanto situações/casos de usuários que possuam alterações e doenças mentais. Nesta perspectiva, as demandas e necessidades relacionadas aparecem, em sua maioria, espontaneamente e a USF é reconhecida como local de referência e acolhimento principalmente para manutenção de medicações e trocas de receita.

Há questões de bipolaridades, esquizofrenias, mas todos já tomam medicação. Então, é mais um manejo de medicação e acompanhamento. Esta é uma demanda que tem crescido bastante. A maioria destes casos vem por troca de receita. Veio trocar a receita do remédio, a gente começa a acompanhar. Muitos casos de depressão vêm por demanda espontânea (Amanda, médica).

caso de depressão a gente descobre em consultório. A pessoa vem numa consulta e começa a chorar. Você vai perguntando e ela começa a destrinchar todos os problemas que tem (Marta, médica).

Ao propor a questão com os profissionais sobre a existência de demandas e necessidades relacionadas ao termo 'sofrimento mental', observa-se um aumento importante de situações/casos. Estas demandas e necessidades são ampliadas para além da concepção de doença mental e têm presença constante no cotidiano do trabalho em saúde.

temos um grau subestimado de saúde mental, tem coisas que não são classificadas, não são ditas de saúde mental, mas como enfermeira acredito que sejam casos da saúde mental sim. (...) um estilo de vida que está levando a uma loucura, por exemplo. (...) tem desde mães, pais, irmãos, que vivem no mundo com conflitos. Têm outros que não, que a gente sabe que é saúde mental mesmo, que tem CID específico de doença mental (Simone, enfermeira).

a grande maioria das pessoas com sofrimento mental adquiriu a doença pelos problemas dos filhos, que são usuários de drogas, que trabalham na boca de fumo; por estado de miséria, ninguém da família tem emprego, nem os filhos, nem a mulher, nem o marido; e por viverem se alimentando de favor. Então, adoecem mentalmente (Marta, médica). 
As situações/casos relacionadas ao sofrimento mental são trazidas a USF principalmente pelos ACS.

muito dificilmente foi feito um diagnóstico sem que o agente comunitário tenha passado o caso. (...). Assim, pela experiência de trabalho, os agentes comunitários aprenderam a distinguir o paciente 'normal' e o paciente de saúde mental. (...) a grande maioria dos casos de saúde mental quem traz é o agente comunitário (Marta, médica).

Em grupo focal, os ACS sobre este tema mesclam suas compreensões, ora vêem a saúde mental enquanto alterações mentais citando diagnósticos e até mesmo confundindo com deficiências mentais, ora com situações de sofrimentos ocasionadas por perdas e/ou faltas (mortes de familiares em situações violentas; perda de emprego; falta de alimentação e moradia; dentre outras situações).

Relatos dos profissionais de saúde reforçam e exemplificam também estas idéias que transitam nas compreensões dos ACS:

Teve mães que perderam os filhos, coisas de violência mesmo, as pessoas eram totalmente normais e sofreram um susto, um baque, um trauma e ficaram com alguma deficiência, com alguma doença mental, e nunca conseguiram se recuperar (Letícia, fisioterapeuta).

um pai estava entrando em depressão, já estava em surto eu acho, porque imagine um pai de família que tem filhos e esposa sem ter o que comer e sem ter as coisas em casa. Ele acabou ficando meio pirado. Não é uma coisa que foi imposta, que ele quis, é algo que veio pela situação (Roberta, enfermeira).

Para intervir nas situações/casos considerados de saúde/sofrimento mental os ACS fazem uma diferenciação: há momentos que eles entendem que os usuários precisam ser ouvidos e acolhidos, esta ação pode ser executada por eles mesmos. Há outros momentos que percebem risco de algum usuário vir a cometer suicídio ou usuários que não estão estabilizados com a medicação (falam sozinhos, vêem 'coisas', agitados), e recorrem diretamente ao psicólogo e ao psiquiatra da ESM. Esta última ação também é citada pelos demais profissionais da ESF.

tentamos abordar os casos de saúde mental da melhor forma, por exemplo, se aparece um caso desses nós assumimos, não mandamos para outro serviço não. Nós sabemos as dificuldades deles, a dificuldade da família. (...). 
Sabemos que a pessoa que pedimos para ir para o hospital, não vai. (...) nós ligamos para o psiquiatra ou para a psicóloga, pedimos para vir à unidade, para dar alguma medicação. O médico daqui também medica. Nós vamos à casa do usuário fazer medicação se ele não vier aqui (Aline, auxiliar de enfermagem).

Quando necessita uma visita, há visita (...) na família pela equipe como um todo. (...). Tem também a discussão junto com a Equipe de Saúde Mental, junto com o psiquiatra e a psicóloga (...) para se tentar um plano de trabalho, um plano de ação conjunto (Amanda, médica).

é um surto, uma crise, a Equipe de Saúde Mental entra junto para fazer essa visita, articular uma medicação, articular outros atores da equipe que vão entrar nesse processo de vínculo e cuidado (Rebeca, psicóloga).

Outros profissionais também problematizam a discussão sobre a ausência de locais de referência e contra-referência quando estão diante de situações/casos que necessitam de internações psiquiátricas. Para eles, isto limita o desempenho e a continuidade do trabalho realizado pelo PSF.

até hoje o nosso grande problema é que temos casos na área em que a pessoa está em surto e tem que ser internada. Nós não temos para onde mandar, não existe referência de internação. Se mandar para o hospital da região, o hospital faz o quê? Impregna esta pessoa de Haldol e manda de volta. O paciente esquizofrênico; psicótico, daquele de tentar matar a irmã, a mãe, o pai; suicidas, que já tentou suicídio, tomou mil e um remédios, veneno, tentou se jogar. Na maioria das vezes não temos respaldo (Marta, médica).

Os profissionais de saúde em diferentes momentos relatam com riquezas de detalhes que identificam, acolhem e viabilizam cuidados, atendimentos e encaminhamentos aos usuários que sofrem mentalmente. Nota-se que este posicionamento sem resistências pode ser justificado pela existência de uma Equipe de Saúde Mental na USF que integra a ESF atendendo e discutindo situações/casos relacionadas ao tema desde sua implantação, aproximadamente há 07 anos.

Como visto, os profissionais de saúde consideram a saúde mental como um fenômeno amplo e complexo, envolvendo desde as alterações mentais que são patológicas até sofrimentos que abrangem aspectos sociais.

Os ACS ao discutirem a origem do sofrimento mental associam-no à doença mental, aos traumas na infância, às perdas violentas e aos problemas decorrentes do momento do 
parto. Uma ACS ao relatar sobre mulher que tinha 'vida normal', mas 'surtou' e enlouqueceu depois que assassinaram seu filho, exemplifica as demais opiniões do grupo que enfatizam as ocorrências de depressões e surtos de usuários após passarem por situações de violência. Para eles, muitos não conseguem recuperar o estado de saúde emocional que possuíam.

Ao tratar as opiniões dos profissionais de saúde sobre o aceitar ou não o sofrimento mental, alguns profissionais afirmam que ele é aceitável, porque consideram parte da vida o sofrer e não uma questão de escolha.

sofrimento mental é aceitável e necessário, tem uma função, (...), às vezes a pessoa precisa adoecer naquela família para que as emoções familiares mudem, precisa ter um surto para que ela pare, (...) precisa ter uma overdose de droga para que ela precise (...). Os adoecimentos, de modo geral, revelam como o sujeito está se relacionando com a sua vida e com o seu entorno. (...) o sofrimento é aceitável, é necessário, o que não é aceitável é não tê-lo (Rebeca, psicóloga).

O sofrimento mental é aceitável sim. (....) não é uma coisa que escolho e falo: "A partir de hoje vou ser uma pessoa com transtorno bipolar”. Então, ninguém escolhe na minha concepção. É um processo e a pessoa sofre com isso. De ser diferente, de não saber o que é ou mesmo não ter um diagnóstico, como que os outros vão vê-la, como que ela vai ser tratada pela comunidade (Luana, terapeuta ocupacional).

é inevitável. Acho que o sofrimento mental faz parte, mas precisa ser trabalhado também, porque a vida envolve um grau de sofrimento mental. Somos trabalhados desde pequenos para conseguirmos suportar, sabermos lidar. (...) cada vez mais percebemos que nem sempre a família consegue criar suporte até para o sofrimento (Aline, fonoaudióloga).

Outros profissionais incluindo o ACS não aceitam o sofrimento mental, porque acreditam que nenhum tipo de sofrimento deva existir. Para eles, caso exista, ele deve ser tratado e minimizado.

nenhum tipo de sofrimento é aceitável. (...) tem que buscar diminuir se não consegue sarar, tratar ou curar. A gente tem que pelo menos buscar uma melhora da qualidade de vida. (...). Nenhum tipo de sofrimento é aceitável em todos os níveis: fisico, mental, emocional (Letícia, fisioterapeuta).

aceitável ele não é. (...) é muito difícil para uma pessoa ter sido normal um dia e de uma hora para outra ficar assim, doente da cabeça, com depressão, com sofrimento mental. E o pior é que dificilmente ela irá voltar a ser uma pessoa como era antes (Telma, cirurgiã-dentista).

nenhum tipo de sofrimento tem que ser aceitável. Ele tem que ser trabalhado, reduzido (Simone, enfermeira). 
Importante ressaltar que esta última percepção não está relacionada ao não aceitar o usuário que possui sofrimento mental no sentido de exclusão da sociedade.

\subsection{REPRESENTAÇÕES DE COMUNIDADE NO TRABALHO EM SAÚDE}

\subsubsection{COMUNIDADE: AS PERCEPÇÕES DOS PROFISSIONAIS DA USF}

Ao problematizar as três temáticas médico-sociais violência, uso abusivo de álcool e drogas, e, saúde mental, pode-se apreender percepções dos profissionais de saúde acerca da comunidade em que atuam. Neste sentido, destacam-se as diferenças entre profissionais moradores da comunidade e não moradores, bem como as contradições sobre o que é aceitável para si e para comunidade ao se depararem com esses temas. Estas contradições podem ser verificadas ao comparar a análise apresentada com o capítulo anterior (itens 6.2.2, 6.2.3 e 6.2.4).

\section{Violência}

Todos os profissionais não moradores da comunidade ao discutirem se a comunidade aceita ou não a violência afirmam categoricamente que a comunidade aceita e se mostra conivente, passiva e até mesmo autora de violência.

Poucos profissionais preservam a não generalização ao pontuar a existência de pessoas da comunidade que repudiam e tentam se afastar da violência, embora acreditem que estas na convivência acabam sendo induzidas a aceitá-la.

acho que sim [para a comunidade a violência é aceitável], porque eles agem e pagam com a mesma moeda. "Aqui se faz, aqui se paga." Eles mesmos procuram resolver entre eles. Então, acho que para eles é aceitável. (...). "Roubou, vai apanhar. Bateu, então, vai morrer. Mexeu com a mulher do outro, vai apanhar." Acho que em tudo eles agem desta forma. "Mexeu com quem estava quieto, agora agüenta.” Não é assim a fala deles? (Camila, auxiliar de enfermagem).

aqui eu vejo pessoas falando: "Vai lá, rouba, faz um movimento e acabou." (...) é uma coisa que eles aceitam, porque se não aceitassem não estariam aqui. "Ah, mas eu não tenho para onde ir. Então, eu tenho que aceitar”. Há muitas pessoas que dizem isto. São pessoas que se trancam em casa à noite, ouvem tiros direto e correrias. É policial que entra, é policial que sai. É o 
filho que vai e se droga. Filho que sai e volta morto. Não volta, ou está preso. Então, é uma violência aceitável até pelo contexto daqui. Traficante aqui dá presentes de natal, cestas básicas, presentes para as crianças, protege (...). (...) e eles [os usuários] ficam coniventes (Amanda, médica).

É estranho, muitas vezes sim [é aceitável para a comunidade a violência]. (...) às vezes, até para as próprias vítimas. (...) talvez o convívio com isto, não sei se para todos, mas eu já vi algumas pessoas (...) que certamente aceitam. (...) eles convivem, porque aquilo acaba ficando no cotidiano. (...) já vi uma mulher falando assim: "Teve uma época que eu saía aqui e tinha três corpos.” Isso é horrível e a pessoa não fala isso como uma coisa normal. Ela sente que é ruim, mas como convive no dia-a-dia, a pessoa acaba assimilando algumas coisas. (...) naturalizando coisas que não fazem sentido (Romeu, psiquiatra).

Alguns profissionais de saúde citam o repudiar da violência pela comunidade, mas este é ocasionado por interferências do tráfico de drogas e da criminalidade no território ao imporem suas 'leis e regras’. Isto não quer dizer que essas 'leis e regras’ não signifiquem também outras violências.

Existe um código de ética. Mesmo entre a violência deles que eles aceitam ou não. Por exemplo, abuso sexual com criança, pedofilia, isso é inaceitável. Tanto que teve um caso que ele foi expulso da área pela 'galera do mal', porque todo mundo sabia. Os caras da boca falaram: "Ou você pára ou você vai morrer.” E aí ele sumiu. Todo mundo sabe dessa história. Então, (...) até é normal você matar um cara, porque ele te xingou. Mas não é normal um cara abusar de uma criança. Eles têm esse poder de Estado, fazem essa função dentro da comunidade. Então, eles têm esse código de ética: o que é certo, o que é errado e como que eles resolvem isso na comunidade (Letícia, fisioterapeuta).

Os ACS sobre essa discussão também expõem diferentes opiniões e não chegam a consensos nos relatos do grupo focal. Uns disseram que a comunidade não aceita de nenhum modo a violência e outros consideram que a comunidade a aceita por medo.

Confrontando as opiniões, uma ACS revelou que a comunidade também aceita a violência no território por esta ser um 'porto seguro’ para muitos. Cita o exemplo que os traficantes e criminosos necessitam de pessoas dispostas a perpetuá-la. Deste modo, a organização do tráfico de drogas se constitui enquanto um meio de emprego para jovens e velhos da comunidade que não conseguem emprego formal e legal. 


\section{Uso abusivo de álcool e drogas}

As opiniões dos profissionais não moradores da comunidade ao discutirem se a comunidade aceita ou não o uso abusivo de álcool divergem bastante. Em determinados momentos afirmam que a comunidade o aceita pela sua naturalização e integração no cotidiano. Em outros, a comunidade não o aceita pelas conseqüências advindas (conflitos familiares, desemprego, violências, perda da auto-estima, etc.).

É aceitável sim. (...) você pega micro-áreas que têm mais de vinte bares com nem duzentas famílias. (...). Não é visto como prejudicial. (...) é visto como social. Muitas vezes começam mesmo no social, seria bom que as pessoas conseguissem se manter no nível do que é normal, do que bebe esporadicamente, do que sabe beber (Aline, fonoaudióloga).

Faz parte do cotidiano, (...), você vê histórias de várias famílias que: “Ah, o meu pai é alcoólatra, meu marido e o meu filho também.” Há vários casos na família e (...) as pessoas lidam naturalmente com isso (Luana, terapeuta ocupacional).

É aceitável. Para eles a bebida é uma coisa normal. (...) você percebe muito isso com os agentes comunitários. Eles têm a cultura da cervejinha e também são moradores do território. (...) teve uma agente comunitária que (...) quase foi demitida por causa do uso de álcool. (...). Ela disse que desde pequenininha ia para os bares dançar para o pai ganhar bebida. A filhinha dançava e o papai ganhava a bebida (Simone, enfermeira).

Olha, eu vou te dizer que não. A comunidade não aceita o uso abusivo de álcool. As pessoas recriminam bastante. (...). Quando chega alguém mais alterado: “Ah, lá vem aquele bêbado chato...” (...). Muitos brigam, reclamam, xingam, mas depois o ignoram. "Ah, esse não tem mais jeito" (Amanda, médica).

Enfaticamente, todos os ACS afirmam que a comunidade aceita o uso abusivo de álcool dado o poder lucrativo do álcool no território. Para eles, possuir um bar ou boteco na região é muito rentável, pois qualquer pessoa pode abrir um e em qualquer lugar, por exemplo, na sua própria garagem. Não há fiscalizações e nem cobranças de impostos.

Uma ACS considera que a comunidade tem preconceitos com aqueles que fazem uso abusivo de álcool.

Presenciei um dono de padaria conversando com um rapaz jovem que até já morreu. O rapaz vivia por aí e foi assassinado. Ele chegou à porta da padaria, eu trabalhava nesta padaria, e o dono falou para ele assim: "Ah, você quer beber?" Ele estava sentado à porta e o dono foi virando a garrafa na boca dele [de propósito]. E eu ali naquela angústia, até por ter problema de álcool 
na minha família. Quando a gente tem parece que é ainda pior. Eu ficava pensando comigo: "Não, isto não está acontecendo". Como eu ia chegar para este cara e dizer: "Pára!” Ele era o patrão, ele podia (Teresa, ACS).

Do mesmo modo que os profissionais de saúde se posicionam quanto ao uso abusivo de álcool, eles dão opiniões sobre o aceitar ou não uso abusivo de drogas pela comunidade.

A maioria dos profissionais, tanto os que moram e os que não moram na comunidade, afirmam que a comunidade não aceita o uso abusivo de drogas.

Não é aceitável pela comunidade, porque não é todo mundo. De $100 \%$ da população, $15 \%$ mexem com isso. (...) eles não aceitam, mas são obrigados a conviverem calados, sem darem opiniões (Marta, médica).

Não é, porque gera muita violência (...). Têm várias situações aqui de violência por drogas, dívidas, pessoas pagando com a própria vida (César, cirurgião-dentista).

não é aceitável, porque senão a gente não teria tantos sofrimentos: o sofrimento dos pais de usuários de drogas, o sofrimento das pessoas que usam, etc. (Andréa, auxiliar de enfermagem).

Destaca-se a opinião de uma profissional que abre a possibilidade de algumas pessoas da comunidade aceitarem e serem coniventes com o uso abusivo de drogas. Entretanto, quando estas se deparam com situações/casos em sua família mudam opiniões e atitudes.

pode ser até totalmente aceitável. Mas tem situações que eles consideram não aceitável, que é isso, quando a pessoa começa a ficar violenta com a família, a furtar as coisas dentro de casa, enfim, quando ela começa a gerar incômodos. (...) aí ela se torna (...) mais inaceitável (Rebeca, psicóloga).

Alguns profissionais também questionam a postura da comunidade que embora não aceite o uso abusivo de drogas possui pessoas que não fazem nada para mudar a realidade onde vivem e permanecem no território sofrendo.

Há muitos moradores que sofrem por não aceitarem as drogas. Mas se sofrem, por que não mudam daqui? A solução é sair. (...). Se você não tem condições de mudar o lugar que mora, então sai. (...) melhorar de vida é sair daqui. Tem gente que está acostumado (...) vivendo muito bem alheio às drogas. (...). Agora para aqueles que sofrem, tem que sair. Não fazem nada para mudar a situação aqui (Raquel, auxiliar de enfermagem).

De forma geral, as ACS sentem que a comunidade não aceita o uso de drogas, mas também não faz nada para mudar a realidade que vivem. (Relatório do Grupo Focal). 


\section{Sofrimento mental}

A maioria dos profissionais de saúde, que não moram na comunidade, considera que a comunidade convive com muitos sofrimentos. Para eles, o sofrimento mental na comunidade é aceitável sim, principalmente, por acreditarem que não há opção de escolha para aqueles que sofrem.

É aceitável porque não é uma coisa que você escolhe. "Ai, quero ter sofrimento mental. Quero ter algum problema.” (...) não é uma coisa que você escolhe como álcool e drogas que você vai atrás. Agora um problema mental ou alguma coisa assim não é você que escolhe (Camila, auxiliar de enfermagem).

Outros afirmam que o sofrimento mental na comunidade não é aceitável em virtude de ser desencadeado pelas complexidades do território; do seu desconhecimento; de provocar exclusões; e de gerar outros sofrimentos nas famílias dos portadores de sofrimento mental.

Na situação aqui não é aceitável. As pessoas sofrem por imposição, elas não sofrem porque querem. Elas sofrem, porque vivem o que elas não querem viver, o que não querem presenciar, o que não gostam, o que não aceitam. (...). Muitas vezes a população não dorme, porque os traficantes colocam o som numa altura desgramada. Ela não aceita, mas pode reclamar? Não pode. Tem voz? Não tem. A comunidade só tem voz para se manter calada. Este é o papel da população, se manter calada, de olhos abertos, mas ao mesmo tempo fechados (Marta, médica).

Se as pessoas da comunidade vêem uma pessoa em surto, na rua ou em casa, as pessoas ficam angustiadas. Não aceitam, lógico que não aceitam (Roberta, enfermeira).

Não é aceitável. Vejo que os familiares de pessoas que têm problemas de saúde mental aqui cuidam, mas sofrem muito. Percebo que são famílias que cuidam mesmo, mas não têm vida. Aquela pessoa que tem algum problema de saúde mental sempre tem que ter mais cuidado. Às vezes, os familiares os excluem um pouco das coisas da família. Eles excluem aquela pessoa de trabalhar, de ter uma vida, de estudar. Tratam mesmo como doentes e acabam também ficando doentes (Andréa, auxiliar de enfermagem).

Alguns profissionais pontuam que para se resolver uma situação que está fora da ‘normalidade’ a ação mais fácil e rápida é retirá-la, extingui-la. Em razão disto, a internação dos portadores de sofrimento mental ainda é tão veiculada pela comunidade.

Aquela gente convive tanto com sofrimentos que (...) tem momentos que eles [comunidade] não querem aceitar. (...) eles preferiam que internasse 
(...), porque percebem que a pessoa está aquém de lidar com aquela circunstância. Embora o sofrimento esteja ali presente continuamente, algumas vezes a pessoa perde a estrutura para lidar até com aquele meio, aquela situação [de sofrimento] (Romeu, psiquiatra).

Já os ACS explicitam que se o sofrimento mental não ocorrer 'dentro de casa', a comunidade o aceita muito bem. As pessoas são solidárias e compreensivas quando sabem que determinada pessoa possui sofrimento mental, mas não sabem como agir e ajudar se for necessário.

Entretanto, os ACS salientam que na comunidade há também aqueles que consideram esses usuários como ‘doidos’, ‘safados’ e 'loucos’, e por conseqüência, os tratam com grande preconceito.

\subsubsection{LIMITES E POTENCIALIDADES DA RELAÇÃO 'SERVIÇO- COMUNIDADE’ E DO TRABALHO EM SAÚDE}

No decorrer dos relatos, os profissionais também revelam diversas percepções sobre os limites e as potencialidades da relação 'serviço-comunidade' e do trabalho em saúde no cotidiano de práticas do PSF. Para elucidá-las neste item, os dados advindos dos relatos serão agrupados.

\section{Limites da relação 'serviço-comunidade’ e do trabalho em saúde}

A maioria dos profissionais marca a estrutura física da USF como um limite do trabalho em saúde, conforme citado no item 6.1, devido à ausência de salas, equipamentos e ambientes apropriados para o atendimento e a realização das demais atividades da unidade, como exemplo, os grupos.

O território e contexto social da comunidade marcados pela miséria, desemprego, tráfico de drogas, criminalidade, baixa escolaridade, desestruturação familiar e a ausência de equipamentos sociais e espaços de lazer para estimular e apoiar o desenvolvimento da comunidade são marcados como limites pelos profissionais. 
Outra questão destacada repetitivamente pelos profissionais é a presença do tráfico de drogas e da criminalidade no território de atuação limitando a relação 'serviço-comunidade’ e o trabalho em saúde.

Percebe-se nesses relatos que a partir do momento que os interesses dos traficantes e criminosos são atingidos, estes impõem barreiras para a execução das intervenções da USF, bem como para o desempenho da relação ‘serviço e comunidade’ através de ameaças físicas e psicológicas aos profissionais de saúde, às vezes, 'recados’ trazidos pelos próprios ACS.

Complementam-se a estes dados os receios dos profissionais não moradores da comunidade em conhecer as histórias de vida e familiar dos usuários da USF e, consequentemente, sofrerem ameaças de morte.

Assim, os profissionais de saúde em geral concluem que abordar cautelosamente a violência e o uso abusivo de álcool e drogas devido à proximidade dos usuários da USF com criminosos e traficantes inseridos na comunidade é muito difícil.

Quanto ao trabalho em saúde, ressalta-se nos relatos a ausência de rede de saúde para dar continuidade ao tratamento iniciado pela USF (referência e contra-referência) em situações graves relacionadas ao uso abusivo de álcool e/ou drogas; de acompanhamentos psicoterápicos e centros de apoio (CAPS, CECCO, CEDECA, etc.) nas proximidades do território da USF para situações/casos relacionados à saúde/sofrimento mental; e de treinamentos e capacitações continuadas para os profissionais de saúde visando o reconhecimento e o melhor atendimento das demandas e necessidades da comunidade.

Quanto à relação ‘serviço de saúde e comunidade’, os profissionais de saúde discutem sobre como abordar usuários que não reconhecem e nem verbalizam suas necessidades de saúde em visitas domiciliares solicitadas pelos ACS; os distanciamentos da ESF como um todo no acolhimento de determinadas famílias por causa de problemas anteriores que prejudicaram essa relação; e a não aceitação dos usuários diante das intervenções propostas 
pelos profissionais de saúde e, portanto, a permanência em atitudes e hábitos geradores de doenças e sofrimentos.

Especificamente, os ACS ao discutirem a relação ‘serviço de saúde e comunidade’ em seus relatos apontam que não conseguem colocar limites e manter a privacidade diante dos usuários, o que gera muitos desgastes nas relações entre eles.

\section{Potencialidades da relação 'serviço-comunidade' e do trabalho em saúde}

Os profissionais de saúde em geral vêem a ótima aceitação do PSF pela comunidade e o estabelecimento de vínculos entre profissionais de saúde e usuários facilitando a relação 'serviço de saúde e comunidade’, bem como as intervenções e os tratamentos propostos pela USF.

Importante ressaltar que a maioria dos profissionais, não moradores da comunidade, nos relatos apontou a introdução do ACS como um facilitador da relação 'serviço de saúde e comunidade’ no PSF; as visitas domiciliares como um recurso de promover proximidades e desvelar situações/casos escondidos no território; e a abordagem familiar como a que favorece o acesso aos problemas e dificuldades vivenciados pelas famílias da comunidade, possibilitando intervenções no sentido de fortalecer o relacionamento, a dinâmica e os vínculos familiares.

Ao discutirem outras potencialidades do trabalho em saúde, os profissionais evidenciam: a realização de grupos e oficinas como intervenções que favorecem o compartilhar de dores e sofrimentos gerando um apoio mútuo entre os participantes; a atuação com uma comunidade circunscrita permite orientar, dar continuidade às intervenções realizadas e ver os resultados obtidos diferente; o desenvolvimento de trabalho em conjunto entre as ESF e as equipes ampliadas (Saúde Bucal, Saúde Mental e de Reabilitação); e, principalmente, a divisão de responsabilidades entre os integrantes da ESF (co- 
responsabilidade). Desta forma, através de conversas e trocas de experiências entre os profissionais da equipe obtém-se um melhor acolhimento dos usuários.

As possibilidades de articulações e parcerias com demais equipamentos e recursos do território, tais como, escolas, creches, Conselho Tutelar, CEDECA, EGJ, CECCO, projetos comunitários, outros serviços de saúde, etc. potencializam o trabalho intersetorial para o reconhecimento de demandas e necessidades da comunidade, e, consequentemente, a realização em conjunto de ações e intervenções.

Por fim, diante de situações/casos relacionados ao sofrimento mental, a inclusão dos usuários nos atendimentos focados na saúde em geral promovidos pela USF e a construção de novas formas de cuidados alternativos à internação psiquiátrica são vistos por todos como potencialidades do PSF.

\subsubsection{SER PROFISSIONAL DE SAÚDE DIANTE DA COMUNIDADE}

Ao analisar os relatos dos profissionais de saúde quando questionados sobre o trabalhar diretamente com a comunidade, bem como com suas demandas e necessidades médico-sociais podem-se destacar algumas percepções sobre ser profissional de saúde diante da comunidade. De modo agrupado, têm-se as análises das percepções:

1. Ser profissional de saúde diante da comunidade é assumir desafios. Para aqueles que sustentam esta opinião, atuar na comunidade é ter o desejo de ser um profissional da 'ponta' do modelo de atenção. Ou seja, lidar diretamente com tudo o que implica a atenção primária em saúde em sua complexidade conforme os estudos de Starfield (2002). Isto não significa realizar ações de saúde ‘básicas’, como enfatizado por Malfitano e Lopes (2003).

no PSF você consegue constituir melhor um trabalho, de fato, grupal, interdisciplinar e transdisciplinar. A realidade do território, as questões sociais muito específicas que têm aqui, a maior vulnerabilidade mesmo por conta destas questões, as questões culturais, isto tudo torna o trabalho um interessante desafio (Aline, fonoaudióloga).

poder fazer um trabalho muito além daquilo que fui ensinada. (...). Aqui no PSF tem a possibilidade de trabalhar questões mais amplas e que são muito mais difíceis, não têm 'receitas de bolo', (...) mas a gente vê mudanças. Você 
vê as pessoas começando a pensar. Coisas que a gente faz com o paciente ou com o grupo e começa às vezes a se repetir na comunidade. A pessoa internaliza isto e vai dividir. Ela vai ser multiplicadora para essa nova forma de pensar na saúde, tanto no que se refere à violência, ao uso de álcool e drogas, à saúde mental. Isso é muito gostoso, ver aquela história de: "Ah, estou plantando a sementinha em vários lugares” (Luana, terapeuta ocupacional).

2. Ser profissional de saúde diante da comunidade é reconhecer a existência de fatores limitantes, que vão desde os governantes e gestores que não promovem mudanças políticas e estruturais até o tráfico de drogas e a criminalidade. Estes preponderam nos relatos e impedem a execução e o desenvolvimento do trabalho em saúde, segundo alguns profissionais.

quando se fala em álcool e drogas, temos que tratar com muita delicadeza, 'pisando em ovos', porque senão a gente corre o risco de ser ameaçado. (...) e não é só o álcool e a droga. A nossa população aqui, ou é presidiário, ou já foi, ou é filho dele, ou é parente dele. Se olhar feio, eles matam. (...). Então, você tem que aprender assim: eles respeitam a nossa unidade, a gente aqui dentro e quando vamos lá fora fazer alguma abordagem. Mas não pise no território que não é para pisar, não toque no assunto que não é para tocar (Roberta, enfermeira).

tem que ser construída iniciativas locais, com atores locais e com um investimento sério e ético de governantes, instâncias, organizações políticas. (...). O problema é que existem muitos estudos produzidos, sabemos de vários indicativos de como fazer as coisas, mas emperra em nossos governantes e gestores que não fazem nada (Rebeca, psicóloga).

3. Ser profissional de saúde diante da comunidade é deparar-se constantemente com frustrações, desânimos e cansaços. Há muitos planejamentos, ações, intervenções, mas o problema central é que os profissionais não vêem os resultados obtidos.

Os limites, já citados, como a ausência de rede de saúde integrada para efetivação de referências e contra-referências, de apoios intersetoriais e políticos e até mesmo de redes de ajuda entre os profissionais da USF fazem com que o profissional sinta-se solitário em meio ao ‘olho do furacão’.

Ampliando esta percepção, nota-se que demandas e necessidades médico-sociais da comunidade consideradas complexas passam a serem esquecidas, banidas, transformadas em ‘tabus’ por ‘profissionais solitários’ nas discussões de situações/casos relacionadas a elas em reuniões de ESF. 
a gente é meio abandonado (...), tudo é (...) problema da saúde, a escola não liga, a ação social não liga, o CAPS não liga, o problema é nosso. A família está aqui e é mesmo problema nosso, mas não é só nosso. Têm muitas coisas que a gente não consegue fazer. (...). Queria saber um pouco mais sobre o que as pessoas pensam, porque a gente não conversa sobre isso [demandas e necessidades da comunidade (violência, álcool e drogas, sofrimento mental)]. (...). A gente não conversa isso em equipe, a gente não conversa nem entre a gente. (...) é tão difícil falar sobre isso, gera tanto sofrimento, tanta frustração, que a gente prefere deixar quieto (Letícia, fisioterapeuta).

a partir do momento que não é mais novidade e que você vê que não é capaz mais de resolver o problema, você já desanima. (...). Você trata e não resolve. Você tenta e não resolve. Você ouve e não resolve. Você busca ajuda e não resolve. Chega um momento em que o médico do PSF desiste, vai embora. (...). (...) a minha diferença já acabou, não tenho mais idéias para melhorar, as estratégias acabaram. São 04 anos na mesma unidade, o que você tinha que fazer, já fez. E o que mais você vai inventar depois de 04 anos? (...) vai cansando, vai deixando de produzir, vai ficando natural. Vai ficando como: "Esse [paciente] aí toda semana vem com a mesma coisa." E não é assim (Marta, médica).

É um serviço de formiguinha, bem lento, mas lento mesmo. Quase não dá nem para se perceber (...). (...) não tinha parado para pensar nessas questões de violência no meu cotidiano, no meu trabalho, na minha vida pessoal. Nunca tinha feito uma reflexão. Nunca tinha nem parado para pensar nisso. Da violência a gente só se tem medo (Raquel, auxiliar de enfermagem).

4. Ser profissional de saúde diante da comunidade é perceber as próprias impotências, incapacidades e falta de conhecimentos diante da multiplicidade e complexidade de demandas e necessidades da comunidade no cotidiano de práticas. Neste sentido, os profissionais de saúde problematizam a ausência de treinamentos e capacitações continuadas que visam à maior resolutividade das ações em saúde.

Sinceramente acho que eu não tenho preparo suficiente para trabalhar com isso. (...) ainda tenho muito pouco conhecimento para trabalhar com estes três temas. (...). Não é um medo meu. Não é um medo de trabalhar com essas pessoas, mas me acho sem perfil para trabalhar com esse tipo de situação. Sempre busco trabalhar em equipe aqui, então fica mais fácil para solucionar as coisas, muito mais fácil para solucionar os problemas. Mas sozinha eu não conseguiria lidar com os problemas. (...) a Secretaria [Municipal], o Estado e até o Ministério da Saúde deveriam se voltar para esse lado que é tão esquecido. (...) deveriam (...) dar também subsídios, condições aos profissionais para saberem mais e para poder atenderem melhor essas pessoas. Existe pouca coisa sendo feita por elas (Roberta, enfermeira).

vou atrás, estudo, procuro. (...). Mas não me sinto preparada, não me sinto mesmo. (...) é difícil você mexer com o sofrimento do outro. Esses temas são coisas que trabalhamos muito no nosso dia-a-dia. (...) a gente discute toda semana o que fazer, o que melhorar (Amanda, médica). 
Todas as ACS sentem que não estão preparadas para trabalhar com estas questões [violência, álcool e drogas, e sofrimento mental]. Dizem que aprendem no dia-a-dia ao desempenhar funções que vão muito além de suas responsabilidades. Em tom de brincadeira dizem que são um pouco psicólogas, assistentes sociais, conselheiras, etc., mas contradizem que não têm este conhecimento técnico para intervir (Relatório do Grupo Focal).

a gente consegue dar uma resposta em muitos casos. (...) pelo menos o que compete ao básico, à saúde básica. (...) em relação à saúde mental, à violência, a tudo isso que a gente conversou acho que falta muito. (...) a gente não vai conseguir, enquanto não tiver uma rede que funcione, enquanto as pessoas não estiverem mais capacitadas, mais seguras para fazer em relação a isso ou aquilo. (...) a visão das pessoas, a cultura mesmo, o entendimento tem que mudar (Letícia, fisioterapeuta).

Ampliando esta discussão percebe-se que houve avanços na atenção primária de saúde, mas não na formação dos profissionais que atuam no SUS.

deveria ter uma capacitação (...). Na verdade, acho que falta um treinamento. Não é fácil lidar com o paciente (...). (...) tem que saber lidar. Eles estavam dando um treinamento em determinada época, mas não teve continuidade (Célio, cirurgião-dentista).

5. Ser profissional de saúde diante da comunidade para alguns é se tornar indiferente dada às complexidades do território de atuação. Ou seja, tentam relativizar as demandas e necessidades da comunidade para conseguirem exercer as suas atividades profissionais de modo pontual e específico. Enquanto se considera tudo natural e/ou normal, não há o porquê de instigar questionamentos e propor intervenções, ou seja, não há mudanças.

acostumei, porque o que acontece aqui é uma rotina do lugar. (...) visitas de violência, de uso de álcool e drogas, de sofrimento mental, de sofrimento familiar, acostumei a trabalhar com isso. (...). (...) apesar que eu nunca tinha parado para analisar. É difícil a gente pensar, porque a gente vai atendendo e vai atendendo. Mas parar para pensar como são essas famílias, a vida e o dia-a-dia deles não (...). (...) sei que o sofrimento das famílias vem pelas três coisas: pela violência do lugar, o uso de álcool e drogas e pelos muitos casos de saúde mental que há aqui (Andréa, auxiliar de enfermagem).

ao meu ver sei lidar bem com a situação, não me aflijo, (...) não que não vai me abalar de alguma forma. (...). Hoje em dia já sei diferenciar bem os atendimentos e deixar o que aconteceu, aqui. (...) acho que acostumei. (...) Cansa também, porque tudo que se propõe não consegue, não dá conta (...) de atender. (...) às vezes a gente: “Ah, não lembro.”, porque há tantos casos assim [de violência, uso abusivo de álcool e drogas, e sofrimento mental] que vêm, aparecem. E que às vezes para gente passam até despercebidos, porque de certa forma já nos acostumamos com essa situação (Camila, auxiliar de enfermagem). 
6. Ser profissional de saúde diante da comunidade é lidar com sofrimentos frente às misérias, faltas, ausências e complexidades das demandas e necessidades do território de atuação. Para alguns profissionais, assumir este posicionamento se torna uma questão de superação pessoal e profissional.

É muito sofrido. (...) vou a uma casa e (...) eles têm todos esses casos juntos. Tem o sofrimento mental, álcool e drogas, violência numa mesma casa além da questão específica para a qual fui chamada. Há dias que é muito difícil mesmo, eu sofro. Você tem que crescer enquanto sujeito, enquanto pessoa. Tem que amadurecer, envelhecer, viver os problemas, errar e acertar para conseguir trabalhar. E nunca se cobrar tanto, porque são coisas que não são nossas. Eu sempre digo isso que o sofrimento do outro é do outro. A gente pode estar do lado dele, caminhar junto, ajudá-lo a compartilhar e através desse compartilhar, ele crescer, se rever e continuar a caminhada. Se eu for carregar comigo todas as histórias que vejo aqui, chego em casa e me mato. Não posso sofrer tanto, (...), mas também tenho as minhas dores (Luana, terapeuta ocupacional).

7. Ser profissional de saúde diante da comunidade é sentir-se implicado e responsável a partir do momento que se estabelece um vínculo com os usuários da comunidade. Como no PSF existe uma proximidade maior baseada na relação ‘serviço de saúde e comunidade’, as dificuldades, as falhas e os limites são também percebidos rapidamente gerando desconfortos, ansiedades e preocupações nos profissionais que buscam estratégias para a resolutividade e melhora de qualidade de vida daqueles que necessitam.

Eu como profissional de PSF (...) me sinto muitas vezes de mãos atadas. Sabendo de tudo o que está acontecendo na comunidade isso é pior ainda. Porque em outros serviços você não sabe, você não tem acesso a essas informações. Aqui a gente sabe. Sei de tudo dessas famílias, sei de todo mundo que atendo. O que pesa é você saber, tentar fazer, fazer e muitas vezes não conseguir resolver e dar uma melhora na qualidade de vida por ' $n$ ' fatores. Conseguir atingir mesmo essa pessoa para que ela melhore a vida dela, melhore o sofrimento, melhore as relações (...). Poxa, estou fazendo parte disto e me sinto responsável também (...). (...) se a gente conseguisse gerar uma mudança aqui hoje, talvez (...). Essa população que a gente atende está chegando hoje doente, desequilibrada, violenta, agressiva, sem perspectivas e isso é que eu vejo para o futuro. (...) vejo que as pessoas estão mais doentes, mais sofridas (Letícia, fisioterapeuta).

8. Ser profissional de saúde diante da comunidade é estar satisfeito por vivenciar ricas experiências com a comunidade, pertencer a uma equipe multiprofissional integrada e obter resultados e retornos positivos quanto ao trabalho realizado. 
Profissionalmente me considero uma pessoa de muita sorte por estar num lugar tão rico para ser trabalhado e por conseguir atingir pequenas coisas, mas que no final se consegue ver o êxito do trabalho (Simone, enfermeira).

faço parte de uma equipe, somos uma equipe. Então, me sinto realizado (...). Tirando coisas tais como dificuldades físicas, materiais, intelectuais, etc., na medida do que posso fazer me sinto satisfeito. Tento cumprir o máximo do que me é permitido e do que sei fazer. Tento dar o máximo (César, cirurgião-dentista).

a gente fica mais humano trabalhando aqui (...). A gente acaba vendo o sofrimento, tudo da vida dos usuários (...). (...) a miséria que eles vivem choca. Você olha e fala: "Meu Deus, como alguém pode viver assim? Conseguir com tanto problema, morando mal, comendo pouco e ainda sorrir (...)?” (Andréa, auxiliar de enfermagem). 


\section{CONSIDERAÇÕES FINAIS}

No presente Estudo de Caso puderam ser apreendidas as representações de comunidade para o trabalho em saúde tendo por base demandas e necessidades médicosociais tal como a tomam os profissionais de saúde que atuam na atenção primária à saúde.

Compreende-se que os profissionais de saúde da USF enfocada possuem percepções multifacetadas acerca da comunidade, o que influencia diretamente o ser profissional de saúde e integrante de uma ESF diante dela.

Contradições, diferenças e polaridades permeiam as discussões sobre as percepções dos profissionais, sendo evidenciados em alguns momentos o estabelecimento de cisões: profissionais moradores da comunidade versus profissionais não moradores da comunidade, os de dentro versus os de fora, para elucidar e problematizar as particularidades do grupo.

Vale salientar que as práticas que vêm sendo estabelecidas pela USF lidam com urgências e problemas de saúde da comunidade a partir do que já está formulado, como programas de atenção, ofertas de serviços e ações. Corrobora com esta idéia a discussão vista a partir do que os profissionais mais reconhecem como demandas e necessidades da comunidade, bem como vêem como limites do trabalho no território pela perspectiva da gestão e organização dos serviços de saúde no município de São Paulo.

Pautar demandas e necessidades médico-sociais da comunidade saindo da lógica tradicional do que é acolhido nos serviços de saúde é se aproximar de questões marginais e realmente incluí-las enquanto debate em um campo programático.

Ao aproximar as interfaces médicas e sociais, algumas reduções se fizeram necessárias na tentativa de problematizar as temáticas na atenção primária à saúde. Entende-se que embora estas temáticas sejam formuladas enquanto problemas de saúde pública, as ações e intervenções frente a elas devem ser constituídas no território da intersetorialidade. 
Não cabe tudo ao setor Saúde, mas este setor pode ser o problematizador para a construção de ações intersetoriais.

Entraram em cena as temáticas compreendidas neste estudo como demandas e necessidades médico-sociais da comunidade: a violência, o uso abusivo de álcool e drogas, e o sofrimento mental.

Ao serem discutidas estas demandas e necessidades são percebidas como 'incômodos' pela equipe multiprofissional, apesar de serem recorrentes no cotidiano do trabalho da USF. Estes 'incômodos', apreendidos nos relatos, se devem aos limites e distanciamentos do trabalho em saúde e da relação ‘serviço de saúde e comunidade’ que interferem diretamente no acolhimento delas.

Diante das potencialidades visualizadas em meio ao emaranhado terreno que se dá a constituição das práticas do PSF, apreende-se que profissionais de saúde podem instigar e integrar abordagens intersetoriais para atuarem com demandas e necessidades médico-sociais da comunidade, dependendo assim, se estas forem desveladas e acolhidas nas práticas de cuidado dos serviços de atenção primária à saúde.

Constitui-se enquanto desafio para a promoção de ações em saúde diante da comunidade o estabelecimento de uma relação 'serviço-comunidade' articulada, que prevê a dimensão intersubjetiva e extrapole os limites das abordagens do indivíduo reduzido ao biológico. Requer, assim, que haja potencialidades nos encontros e interações entre profissionais de saúde/serviços de saúde e usuários/comunidade.

A análise aqui apresentada torna-se, portanto, o ponto de partida para as novas investigações que vislumbram construir estratégias para fortalecimento do trabalho em saúde diante da comunidade, reconhecendo que este também se encontra no campo da intersetorialidade. 


\section{REFERÊNCIAS BIBLIOGRÁFICAS}

ADORNO, S. Crime e violência na sociedade brasileira contemporânea. Jornal de Psicologia-PSI, n. Abril/Junho, p. 7-8, 2002.

ADORNO, S. A violência brasileira e suas implicações. Curso Sociologia da Violência. Material didático. Mimeo. p. 1-17, 2003.

ALMEIDA FILHO, N. Uma breve história da epidemiologia. In: ROUQUAYROL; M. Z.; ALMEIDA FILHO, N. (org.) Epidemiologia \& Saúde. Rio de Janeiro: 6a ed., pp. 01-16, MEDSI, 2003.

ALENCAR, T. M. D. A vida crônica é novidade na aids: as transformações da aids aguda para o aids crônica sob o ponto de vista dos pacientes. 2006. 237 f. Dissertação (Mestrado em Ciências) - Faculdade de Medicina, Universidade de São Paulo, São Paulo, 2006.

ANDRADE, L. O. M.; BARRETO; I. C. H. C.; BEZERRA, R. C. Atenção primária e estratégia saúde da família In: CAMPOS, G. W. S.; MINAYO, M. C. S.; AKERMAN, M.; DRUMOND JÚNIOR, M. CARVALHO, Y. M. (orgs) Tratado de Saúde Coletiva. São Paulo: HUCITEC; Rio de Janeiro: Ed. FIOCRUZ, 2007, 2a ed, p. 615-634.

AYRES, J. R. C. M. Sujeito, intersubjetividade e práticas de saúde. Ciência \& Saúde Coletiva, ABRASCO, Brasília, v. 6, n. 1, p. 63-72, 2001.

BAPTISTA, M. Faces de um tema proscrito: toxicomanias e sociedade. In: MINAYO, M. C. S.; Coimbra Júnior, C. E. A. Críticas e atuantes: ciências sociais e humanas em saúde na América Latina. Rio de Janeiro: Fiocruz, 2005. p. 609-618.

BARIÇÃO, S. M. F. O Centro de Atenção Psicossocial: desafios no percurso institucional. In: Caderno de Textos da III Conferência Nacional de Saúde Mental. Brasília: 2001.

BARROS, D. D.; GHIRARDI, M. I. G.; LOPES, R. E. Terapia ocupacional social. Revista de Terapia Ocupacional da Universidade de São Paulo. Vol.13, n.3, p.95-103, 2002.

BATISTA, K. B. C. Violência contra mulher e Programa Saúde da Família: a emergência da demanda na visão dos profissionais. In: VILLELA, W.; MONTEIRO, S. (Orgs.). Gênero e saúde: Programa Saúde da Família em questão. Rio de Janeiro : ABRASCO; Brasília : UNFPA, 2005. p. 119-37.

BECKER, H. S. Método de pesquisa em ciências sociais. São Paulo: Hucitec, 1993.

BIRMAN, J.; COSTA, J. F. Organização de instituições para uma psiquiatria comunitária. In: AMARANTE, P. D. C. (org) Psiquiatria social e reforma psiquiátrica. Rio de Janeiro: Ed. FIOCRUZ, 1994, p. 41-72.

BRASIL. Ministério da Saúde. Política Nacional de Redução da Morbimortalidade por Acidentes e Violências. Brasília, 2001.

BRASIL. Ministério da Saúde. Apostila Sociedade Viva: violência e saúde. Brasília, 2003a.

BRASIL. Ministério da Saúde. A política do Ministério da Saúde para atenção integral a usuários de álcool e outras drogas. Brasília: Ministério da Saúde; 2003b. 
BRASIL. Impacto da violência na saúde dos brasileiros. Brasília: Ministério da Saúde, 2005a.

BRASIL. Cartilha sobre maconha, cocaína e inalantes. Série: Por dentro do assunto: Drogas SENAD (Secretaria Nacional Antidrogas). Brasília: SENAD, $2005 \mathrm{~b}$.

CAMPOS, G. W. S. Reflexões temáticas sobre eqüidade e saúde: o caso do SUS. Saúde e Sociedade, São Paulo, v. 15, n. 2, p. 23-33, 2006.

CARNEIRO JR., N.; SILVEIRA, C. Organização das práticas de atenção primária em saúde no contexto dos processos de exclusão/inclusão social. Cad. Saúde Pública, Rio de Janeiro, v. 19, n. 6, p. 1827-35, 2003.

CARNEIRO JR., N.; ANDRADE, M.C.; LUPPI, C. G.; SILVEIRA, C. Organização de práticas de saúde equânimes em atenção primária em região metropolitana no contexto dos processos de inclusão e exclusão social. Saúde e Sociedade, São Paulo, v. 15, n. 3, p. 30-39, 2006.

CASTIEL, L. D. Promoção de saúde e a sensibilidade epistemológica da categoria 'comunidade'. Rev. Saúde Pública, 38 (5), p. 615-622, 2004.

CHASSAING, J. L. Para além da linguagem, o êxtase. Revista Mente e Cérebro. Coleção: O Olhar Adolescente. Tempo de paixões. ed. 02. São Paulo : Editora Ediouro, [2007?].

COHN, A.; NAKAMURA, E.; COHN, C. O Programa de Saúde da Família entre o público e o privado. In: VIANA, A. L. d’Á.; ELIAS, P. E. M.; IBAÑES, N. (Orgs.). Proteção Social: dilemas e desafios. São Paulo : HUCITEC, 2005. p. 168-85.

COUTO, M. T.; SCHRAIBER, L. B. Homens, Saúde e Violência: novas questões de gênero no campo da saúde coletiva. In: MINAYO, M. C. S.; COIMBRA JÚNIOR, C. E. A. Críticas e atuantes: ciências sociais e humanas em saúde na América Latina. Rio de Janeiro: Fiocruz, 2005. p. 687-706.

CREVELIM, M. A.; PEDUZZI, M. A participação da comunidade na equipe de saúde da família. Como estabelecer um projeto comum entre trabalhadores e usuários? Ciência \& Saúde Coletiva, ABRASCO, Brasília, v. 10, n. 2, p. 323-27, 2005.

CRUZ-NETO, O.; MOREIRA, M. R. Trabalho infanto-juvenil: motivações, aspectos legais e repercussão social. Cad. Saúde Pública, Rio de Janeiro, 14(2), p. 437-441, abr-jun, 1998.

D’OLIVEIRA, A. F. P. L. Violência de gênero, necessidades de saúde e uso de serviços de saúde em atenção primária. São Paulo. 2000. Tese (Doutorado) Faculdade de Medicina. Universidade de São Paulo. 279 pp.

DELGADO, P. G. G.; SCHECHTMAN, A.; WEBER. R.; AMSTALDEN, A. F.; BONAVIGO, E.; CORDEIRO, F.; PÔRTO, K.; HOFFMANN, M. C. C. L.; MARTINS, R.; GRIGOLO, T. Reforma psiquiátrica e política de saúde mental no Brasil: conferência regional de reforma dos serviços de saúde mental - 15 anos depois de Caracas. In: MELLO, M. F.; MELLO, A. A. F.; KOHN, R. (orgs) Epidemiologia da saúde mental no Brasil. Porto Alegre : Artmed, 2007, p. 39-84. 
DESLANDES, S. F. Frágeis deuses: profissionais da emergência entre os danos da violência e a recriação da vida. 20. ed. Rio de Janeiro : Editora Fiocruz, 2002.

DESLANDES, S. F.; GOMES, R. A pesquisa qualitativa em serviços de saúde: notas teóricas. In: BOSI, M. L. M.; MERCADO, F. J. (Orgs.). Pesquisa qualitativa de serviços de saúde. Petrópolis: Editora Vozes, 2004, p. 99-120.

DIEMEN, L. V.; KESSLER, F. H. P.; PECHANSKY, F. Drogas: uso, abuso e dependência. In: DUNCAN, B. B.; SCHMIDT, M.I.; GIUGLIANI, E. R. J. (Orgs.). Medicina ambulatorial: condutas de atenção primária baseadas em evidências. $3^{\mathrm{a}}$ ed. $4^{\mathrm{a}}$ reimpressão. Porto Alegre : Artmed, 2006. p. 917-31.

DURAND, J. G. Gestação e violência: estudo com usuárias de serviços públicos de saúde da Grande São Paulo. 2005. 220 f. Dissertação (Mestrado em Ciências) - Faculdade de Medicina, Universidade de São Paulo, São Paulo, 2005.

ELIAS, P. E. Estrutura e organização da atenção à saúde no Brasil. In: COHN, A.; ELIAS, P. E. (org.) Saúde no Brasil: Políticas e Organização de Serviços. São Paulo: Editora Cortez/ Centro de Estudos e Cultura Contemporânea - CEDEC, 2005, 6 ${ }^{\text {a }}$ ed., p.59-119.

ELIAS, P. E.; COHN, A. A construção da cidadania: lições e experiências de participação nos Conselhos de Gestão. Mimeo. 1995.

ELIAS, P. E.; FERREIRA, C. W.; ALVES, M. C. G.; COHN, A.; KISHIMA, V.; ESCRIVÃO JR, A.; GOMES, A.; BOUSQUAT, A. Atenção Básica em Saúde: comparação entre PSF e UBS por estrato de exclusão social no município de São Paulo. Ciência \& Saúde Coletiva, ABRASCO, Brasília, v. 11, n. 3, p. 633-41, 2006.

FERreirA, A. B. H. Novo Dicionário Aurélio da Língua Portuguesa. 3a. edição, revista e atualizada. Curitiba: Editora Positivo, 2004.

FERRIOLLI, S. H. T.; MARTURANO, E. M.; PUNTEL, L. P. Contexto familiar e problemas de saúde mental infantil no Programa de Saúde da Família. Rev Saúde Pública, v.41 nº2, São Paulo : 2007.

GOMES, R.; SOUZA, E. R.; MINAYO, M. C. S.; SILVA, C. F. R. Organização, processamento, análise e interpretação de dados: o desafio da triangulação. In: MINAYO, M. C. S.; ASSIS, S. G.; SOUZA, E. R. (Orgs.). Avaliação por triangulação de métodos: abordagem de programas sociais. Rio de Janeiro: Fiocruz, 2005. p. 185-221.

GOULART, F. A. A. Experiências em Saúde da Família: cada caso é um caso? Tese (doutorado em Saúde Pública) - Escola Nacional de Saúde Pública, Fundação Oswaldo Cruz, Rio de Janeiro: 2002, p.378.

IZIQUE, C. O mapa da exclusão. Revista Pesquisa FAPESP. São Paulo, n.83, jan. 2003. Política Científica e Tecnológica, p. 14-20.

JORGE, M. R. Diagnóstico e classificação em psiquiatria. In: LARANJEIRA, R.; NICASTRI, S. Abuso e dependência de álcool e drogas. In: ALMEIDA, O. P.; DRACTU, L.; LARANJEIRA, 
R. (Orgs.). Manual de Psiquiatria. Rio de Janeiro : Editora Guanabara-Koogan S. A., 1996. p. 22-31.

KISS, L. B. Temas médico-sociais e a intervenção em saúde: a violência contra mulheres no discurso dos profissionais. 2004. f. Dissertação (Mestrado em Ciências) - Faculdade de Medicina, Universidade de São Paulo, São Paulo, 2004.

KRONBAUER, J. F. D.; MENEGHEL, S. N. Perfil da violência de gênero perpetrada por companheiro. Rev Saúde Pública, São Paulo : v.39, n5, p.695-701, 2005.

KRUG, E. G.; DAHLBERG, L.L.; MERCY, J.A.; ZWI, A.B.; LOZANO, R. (eds.). World report on violence and health. Geneva: World Health Organization, 2002.

LANCETTI, A. SaúdeLoucura: saúde mental e saúde da família. São Paulo : HUCITEC, Vol. 7, 2001.

LANCETTI, A.; AMARANTE, P. Saúde Mental e Saúde Coletiva. In: CAMPOS, G. W. S.; MINAYO, M. C. S.; AKERMAN, M.; DRUMOND JÚNIOR, M. CARVALHO, Y. M. (orgs) Tratado de Saúde Coletiva. São Paulo: HUCITEC; Rio de Janeiro: Ed. FIOCRUZ, 2007, $2^{\text {a }}$ ed., p. 615-634.

LARANJEIRA, R.; NICASTRI, S. Abuso e dependência de álcool e drogas. In: ALMEIDA, O. P.; DRACTU, L.; LARANJEIRA, R. (Orgs.). Manual de Psiquiatria. Rio de Janeiro : Editora Guanabara-Koogan S. A., 1996, p. 83-112.

LOPES, R. E.; PALMA, A. M. Possibilidades e limites da terapia ocupacional no Programa de Saúde da Família - PSF: FASE I. 2005. Pró-Reitoria de Pós-Graduação e Pesquisa da UFSCar. 2005,100p.

LOPES, R. E.; PALMA, A. M.; REIS, T. A. M. A experimentação teórico-prática do aluno de terapia ocupacional no campo social: uma vivência com a população em situação de rua. Revista de Terapia Ocupacional da Universidade de São Paulo. Vol.16, n.2, p.54-61, 2005.

LOPES, R. E.; MALfITANO, A. P. S.; PALMA, A. M.; FURLAN. P. G.; BRITO, E. M. Ações básicas de saúde e a construção do SUS: cidadania, direitos e políticas públicas. 2007. Laboratório METUIA : Universidade Federal de São Carlos : CNPq : Ministério da Saúde. 2007, 247p.

MACHADO, K. Como anda a Reforma Psiquiátrica? Revista Radis - Comunicação em Saúde, n ${ }^{\circ}$ 38, out, 2005, p.11-19.

MALFITANO, A. P. S.; LOPES, R. E. Programa de Saúde da Família e agentes comunitários: demandas para além da saúde básica. Rev. Ter. Ocup. Univ. São Paulo, São Paulo, v.14, n. 3, p.110-17, 2003.

MARSIGLIA, R. M. G.; SILVEIRA, C.; CARNEIRO JR, N. Políticas sociais: desigualdade, universalidade e focalização na saúde no Brasil. Saúde e Sociedade. São Paulo : v.14, n.2, p.69-76, maio-ago, 2005. 
MERHY, E. E. Cuidado com o cuidado em saúde: saber explorar seus paradoxos para um agir manicomial. In: MERHY, E. E.; AMARAL, H. (Orgs.) A Reforma psiquiátrica no cotidiano II. São Paulo, Hucitec, 2007. p. 25-37.

MICHAUD, Y. A violência. São Paulo: Editora Ática,1989.

MINAYO, M. C. S. A violência social sob a perspectiva da saúde pública. Cad. Saúde Pública, Rio de Janeiro, 10 (supl. 1), p.07-18, 1994.

MINAYO, M. C. S; DESLANDES, S. F. A complexidade das relações entre drogas, álcool e violência. Cad. Saúde Pública, Rio de Janeiro, 14 (supl. 1), jan-mar, 1998, p.35-42.

MINAYO, M. C. S. A difícil e lenta entrada da violência na agenda do setor saúde. Cad. Saúde Pública, Rio de Janeiro, vol.20, nº.3, p.646-647, 2004.

MINAYO, M. C. S. O desafio do conhecimento: pesquisa qualitativa em saúde. São Paulo : 10. ed. HUCITEC, 406p., 2007.

MINAYO, M. C. S. \& SANCHES, O. Quantitativo-Qualitativo: Oposição ou Complementaridade? Cad. Saúde Pública, Rio de Janeiro, v. 9, n. 3, p. 239-262, 1993.

MINAYO, M. C. S. \& SOUZA, E. R. Violência e saúde como campo interdisciplinar e de ação coletiva. História, Ciências, Saúde - Manguinhos, Rio de Janeiro, 1998.

MINISTÉRIO DA SAÚDE. Saúde da Família uma Estratégia para Reorientação do Modelo Assistencial. Brasília, 1997.

MINTO, E. C.; CORRADI-WEBSTER, C. M.; GORAYEB, R.; LAPREGA, M.R.; FURTADO, E. F. Intervenções breves para o uso abusivo de álcool em atenção primária. Epidemiol. Serv. Saúde, Brasília: 16(3), p. 207-220, jul-set, 2007.

MORAES, M. O modelo de atenção integral à saúde para tratamento de problemas decorrentes do uso de álcool e outras drogas: percepções de usuários, acompanhantes e profissionais. Ciência \& Saúde Coletiva, 13(1), 2008, p.121-133.

MORGADO, R. Resenhas: Brasil. Impacto da violência na saúde dos brasileiros. Brasília: Ministério da Saúde, 2005, 340p. Ciência \& Saúde Coletiva, 11(2), p.537-540, 2006.

MOSCOVICI, S. A representação social da psicanálise. Rio de Janeiro: Zahar, 1978.

MOSCOVICI, S. Representações sociais: investigações em psicologia social. Petrópolis: Vozes, 2007.

MOURA, A. T. M. S.; REICHENHEIM, M. E. Estamos realmente detectando violência familiar contra a criança em serviços de saúde? A experiência de um serviço público do Rio de Janeiro, Brasil. Cad. Saúde Pública, Rio de Janeiro: 21(4), p. 1124-1133, jul-ago, 2005.

NEMES, M. I. B. Prática programática em saúde. In: SCHRAIBER, L. B.; NEMES, M. I. B.; MENDES-GONÇALVES, R. B. (Orgs.). Saúde do Adulto: programas e ações na unidade básica. 2. ed. São Paulo : HUCITEC, 2000. p. 48-65. 
NUNES, E. D. Saúde Coletiva: uma história recente de um passado remoto. Prática programática em saúde. In: CAMPOS, G. W. S.; MINAYO, M. C. S.; AKERMAN, M.; DRUMOND JÚNIOR, M. CARVALHO, Y. M. (orgs) Tratado de Saúde Coletiva. São Paulo: HUCITEC; Rio de Janeiro: Ed. FIOCRUZ, 2007, 2 ed, p.19-40.

NUNES, C. B.; SARTI, C. A.; OHARA, C. V. S. Concepções de profissionais de saúde sobre a violência intrafamiliar contra a criança e o adolescente. Rev. Latino-Am. Enfermagem, Ribeirão Preto: 16(1), p.136-141, 2008.

ONOCKO-CAMPOS, R. T.; FURTADO, J. P. Entre a saúde coletiva e a saúde mental: um instrumental metodológico para avaliação da rede de Centros de Atenção Psicossocial (CAPS) do Sistema Único de Saúde, Cad. Saúde Pública, Rio de Janeiro, 22 (5), p. 1053-1062, mai, 2006.

ORGANIZACIÓN MUNDIAL DA SAÚDE - OMS. Atención primaria de salud. Informe de la Conferencia Internacional sobre Atención Primaria de Salud. Alma-Ata (URSS), 6-12 de septiembre de 1978, Ginebra: 1978.

ORGANIZAÇÃO MUNDIAL DA SAÚDE - OMS. Relatório sobre a saúde no mundo 2001 Saúde Mental: nova concepção, nova esperança. Genebra: Organização Mundial da Saúde, 2001.

OSIATYNSKA, E. Álcool e Saúde. In: Brasil. Álcool e redução de danos: uma abordagem inovadora para países em transição / Ministério da Saúde, Secretaria de Atenção à Saúde, Departamento de Ações Programáticas Estratégicas. 1. ed., Brasília: Ministério da Saúde, 2004, p. 37-47.

PAIM, J. S. Modelos de atenção e vigilância da saúde. In: ROUQUAYROL; M. Z.; ALMEIDA FILHO, N. (org.) Epidemiologia \& Saúde. Rio de Janeiro: 6a ed., pp. 567-586, MEDSI, 2003.

PAlmA, A. M.; COUTO, M. T. Saúde do Adulto e Projeto de Atenção Básica em Saúde da Família - proximidades e distanciamentos sob a ótica da atuação profissional dos agentes comunitários de um Centro de Saúde Escola. 2006. 54 f. Monografia (Especialização Saúde Coletiva) - Faculdade de Medicina, Universidade de São Paulo, São Paulo, 2006.

PORTO, M. S. G. Violência e meios de comunicação de massa na sociedade contemporânea. Sociologias, jul./dez., $n^{\circ} .8$, p.152-171, 2002.

PREFEITURA MUNICIPAL DE SÃO PAULO. Avaliação do impacto dos serviços AMA na produção dos estabelecimentos de saúde do Município de São Paulo. - CEInfo Coordenação de Epidemiologia e Informação - SMS - PMSP, 2007.

PREFEITURA MUNICIPAL DE SÃO PAULO. Secretaria Municipal de Saúde. Disponível em: http://portal.prefeitura.sp.gov.br/secretarias/saude/organizacao/0006 Acesso em: 28 de dezembro de 2008. 
PRÓ-REITORIA DE DESENVOLVIMENTO UNIVERSITÁRIO - PRDU. Programa de prevenção ao uso de substâncias psicoativas lícitas e ilícitas na UNICAMP - Glossário. Disponível em: http://www.prdu.unicamp.br/vivamais/glossario.html. Acesso em: 22 de maio de 2008.

PROGRAMA ÁLCOOL E DROGAS - PAD DO HOSPITAL ISRAELITA ALBERT EINSTEIN. Álcool $\mathrm{e}$ Drogas sem Distorção. Disponível em: http://aed.one2one.com.br/novosite/drogas conceito.htm Acesso em: 23 de maio de 2008.

RAMOS, S. O papel das ONGs na construção de políticas de saúde: a Aids, a saúde da mulher e a saúde mental. Ciência \& Saúde Coletiva, 9(4), p.1067-1078, 2004.

SALA, A.; NEMES, M. I. B.; COHEN, D. D. Metodologia de avaliação do trabalho na atenção primária à saúde. Cad. Saúde Pública, Rio de Janeiro, 14(4), p. 741-751, out-dez, 1998.

SANTOS, D. A. Políticas Públicas e Família: o Programa de Saúde da Família em questão. Coletânea Sobre Família e Gênero. In: CAMPOS, R. B. C.; HOFFNAGEL, J. C. (Orgs.). Pensando Família, Gênero e Sexualidade. Recife : Editora Universitária, 2006. p. 01-20.

SANTOS, N. O.; KRETZER, M. R.; MATOS, M. P. S. A. O território de atuação. In: FERNANDES, M. E. L.; DOWBOR, T. P.; KRETZER, M. R.; GOUVEIA, I.; SUCUPIRA, A. C.; MENEZES, L.; RESEGUE, R. (Orgs.). AIDS: prevenção porta a porta : construindo histórias de prevenção ao HIV/AIDS no Programa de Saúde da Família da cidade de São Paulo. São Paulo : Associação Saúde da Família : Editora Hucitec, 2004. p. 55-59.

SCHRAIBER, L. B.; MENDES-GONÇALVES, R. B. Necessidades de saúde e atenção primária. In: SCHRAIBER, L. B.; NEMES, M. I. B.; MENDES-GONÇALVES, R. B. (Orgs.). Saúde do Adulto: programas e ações na unidade básica. 2. ed. São Paulo : HUCITEC, 2000. p. 29-47.

SCHRAIBER, L. B.; D’OLIVEIRA, A. F. P. L.; FRANÇA JR, I.; PINHO, A. A. Violência contra a mulher: estudo em uma unidade de atenção primária à saúde. Rev. Saúde Pública, São Paulo, v. 36, n. 4, p. 470-77, 2002.

SCHRAIBER, L. B.; D’OLIVEIRA, A. F. P. L.; COUTO, M. T. Violência e saúde: estudos científicos recentes. Rev. Saúde Pública, São Paulo, v. 40, (N Esp), p.112-20, 2006.

SCHRAIBER, L. B.; D’OLIVEIRA, A. F. P. L.; COUTO, M. T; HANADA, H.; KISS, L. B.; DURAND, J. G.; PUCCIA, M. I.; ANDRADE, M. C. Violência contra mulheres entre usuárias de serviços públicos de saúde da Grande São Paulo. Rev. Saúde Pública, São Paulo, v. 41, n. 3, p. 359-67, 2007.

SCLIAR, M. Apresentação. In: DUNCAN, B. B.; SCHMIDT, M.I.; GIUGLIANI, E. R. J. (Orgs.). Medicina ambulatorial: condutas de atenção primária baseadas em evidências. $3^{\mathrm{a}}$ ed. $4^{\mathrm{a}}$ reimpressão. Porto Alegre : Artmed, 2006.

SENAD. Mapeamento das instituições governamentais e não-governamentais de atenção às questões relacionadas ao consumo de álcool e outras drogas no Brasil - 2006/2007: Relatório. Universidade de Brasília. Brasília: Secretaria Nacional Antidrogas - Senad, 2007. 
SENAD. Secretaria Nacional Antidrogas - SENAD. Disponível em: http://www.senad.gov.br/ Acesso em: 23 de maio de 2008.

SILVA, R. C.; SIMON, C. P. Sobre a diversidade de sentidos de comunidade. Rev. PSICO, Porto Alegre, PUCRS, v. 36, n. 1, pp. 39-46, jan./abr., 2005.

SOMARRIBA, M. Os deslocamentos atuais do campo das ciências sociais em saúde: notas de uma orientadora. IN: VASCONCELOS, E. M. Educação popular e a atenção à saúde da família. 2. ed. - São Paulo : HUCITEC, Sobral: Uva, 2001.

SOUSA, G. C. O agente comunitário de saúde e a saúde mental: percepções e ações na atenção às pessoas em sofrimento mental. 2007. Dissertação (Mestrado) - Escola de Enfermagem, Universidade de São Paulo, São Paulo, 2007.

SOUZA, E. R. Violência velada e revelada: estudo epidemiológico da mortalidade por causas externas em Duque de Caxias, Rio de Janeiro. Cad. Saúde Pública. Rio de Janeiro, nº. 9, p. 48-64, 1993.

SOUZA, E. R.; LIMA, M. L. C.; VEIGA, J. P. C. Violência interpessoal: homicídios e agressões. In: BRASIL. Impacto da violência na saúde dos brasileiros. Brasília: Ministério da Saúde, 2005.

STARFIELD, B. Atenção primária: equilíbrio entre necessidades de saúde, serviços e tecnologia. Brasília : UNESCO, Ministério da Saúde, 2002.

STRONACH, B. Álcool e redução de danos. In: BRASIL. Álcool e redução de danos: uma abordagem inovadora para países em transição / Ministério da Saúde, Secretaria de Atenção à Saúde, Departamento de Ações Programáticas Estratégicas. 1. ed., Brasília: Ministério da Saúde, 2004, p. 29-35.

TENÓRIO, F. A reforma psiquiátrica brasileira, da década de 1980 aos dias atuais: história e conceito. História, Ciências, Saúde - Manguinhos. Rio de Janeiro, vol. 9(1), p. 25-59, jan.-abr., 2002.

TORRE, E. H. G.; AMARANTE, P. Protagonismo e subjetividade: a construção coletiva no campo da saúde mental. Ciência \& Saúde Coletiva, vol. 6 (1), p. 73-85, 2001.

VIANA, A. L. d'A.; DAL POZ, M. R. A Reforma do Sistema de Saúde no Brasil e o Programa de Saúde da Família. Physis: Revista Brasileira de Saúde Coletiva, 8(2), p. 11-48,1998.

VIANA, A. L. D.; FAUSTO, M. C. R. Universalismo x focalismo e espaço não mercantil da assistência. In: VIANA, A. L. D; ELIAS, P. E. M.; IBAÑEZ, N. (orgs) Proteção social: dilemas e desafios. São Paulo : Hucitec, 2005. p.150-166.

VILLELA, W.; MONTEIRO, S. Atenção à saúde das mulheres: historicizando conceitos e práticas. In: VILlela, W.; MONTEIRO, S. (Orgs.). Gênero e saúde: Programa Saúde da Família em questão. Rio de Janeiro : ABRASCO; Brasília : UNFPA, 2005. p. 15-31.

ZALUAR, A. Violência e crime. In: MICELI, S. (org.). O que ler nas ciências sociais brasileiras (1970-1995). São Paulo: ANPOCS, 1999, vol.1, p. 13-107. 


\section{ANEXOS}

\section{ANEXO A - PARECERES DOS COMITÊS DE ÉTICA}

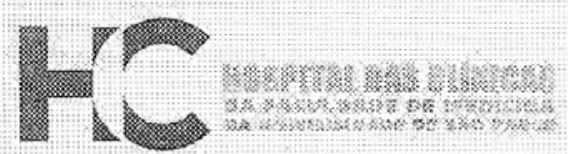

\section{APROVAÇĀO}

A Comissão de Ética para Análise de Projetos de Pesquiso CAPPesa da Diretoria Clínica do Hospital das Clinicas e da Faculiade de Medicina da Universidade de Säo Paulo. em sessão de 30/01/2008, APROVOU o Protocolo de Pesquisa n' 1104/07, intitulado: "O SIGNHFICADO DE COMUNIDADE PARA O TRABALHO EM SAÚdE: DEMANDAS E NECESSIDADES MÉdICO-SOCIAIS NO COTIDIANO OE PRÁTICAS DO PROGRAMA DE SAÚDE DA FAMILIA" apresentado pelo Departomonto de MEDICINA PREVENTIVA, inclusive o Terrio de Consentimenio uyre e Esciarecido.

Cabe ao pesquisador elaborar e apresentar à CAPPesq. os relarórios parciais e final sobre a pesquisa IResoluçăo do Conseiho Naciona: de Saude $n^{\circ} 196$, de 10/10/1996. inciso X.2. letra ' $\mathrm{l}$ ).

Pesquisador (a) Responsável: Marcia Thereza Couto Faicāo

Pesquisador (a) Executante: Ariane Machado Paima

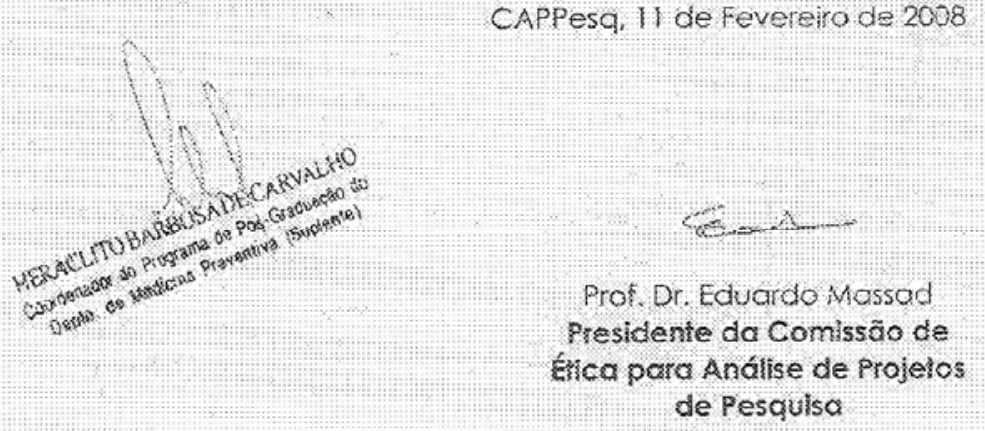

Comissăo ce Ética para Arálise de Projetos de Pesquisa do HCFMUSP e da FMuSP Daretoria chinica do Hospital das Clinicas ca

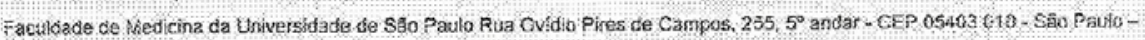

SP Fone: 0:1 3039 6442 Fax: 01130696492 e-mast cappesq@hcret usp. br $/$ secrelariacappese2Qhicnet usp.br

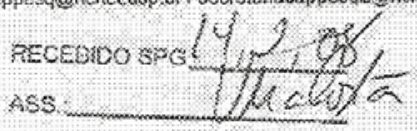


São Paulo, 27 de dezembro de 2007.

PARECER N $N^{\circ} 316 / 07$ - CEP/SMS

CAAE: 0148.0.162.000-07

Para

ARIANE MACHADO PALMA

Sr(a) Pesquisador(a)

\section{IDENTIFICACÃO}

- Projeto de Pesquisa: O SIGNIFICADO DE COMUNIDADE PARA O TRABALHO EM SAÚDE: DE MANDAS E NECESSIDADES MÉDICO-SOCIAIS NO COTIDIANO DAS PRÁTICAS DO PROGRAMA DE SAÚDE DA FAMILIA

Pesquisador Responsável: ARIANE MACHADO PALMA

- Orientadora: Márcia Tereza Couto

- Instituição: FACULDADE DE MEDICINA DA USP - Programa de Pós Graduação em Medicina Preventiva.

- Local onde os dados serão coletados: UBS

\section{- Sumário Geral do Protocolo}

- A autora repassa as mudanças na história da saúde pública desde a declaração de Alma-Ata (1978) que introduziu o princípio dos cuidados primários; ao defini-los, a declaração introduz a noção de comunidade, distinguindo "atenção prestada a indivíduos ou familias e a atenção prestada à comunidade". A autora traz então o tema para o Brasil, discorrendo sobre a implantação do SUS e seus desdode. A autora traz enta o o periminados, a pesquisadora inicia o percurso da pesuibramentos. Para atingir os objetivos abaixo discriminados, a pesquisadora inicia o percurso da pesqui sa com uma revisão bibliográfica que lhe permite delimitar melhor sua questäo. Propōe-se então realizar "pesquisa qualitativa, especificamente como estudo de caso (define ejustifica a

universo será constituido de profissionais da esf "em strevistas em profundidade (semi-estruturada) e grupo focal.

- Quanto aos procedimentos: utilizara entrevistas em profundidade (semi-estruturada) enfermeiros. Equipe ampliada: 2 odontólo-

- Entrevistas - Equipe nuclear : 2 médicos generalistas e 2 enfermeiros. Equipe ampliada: 2 odontólogos, 1 psicólogo ou terapeuta ocupacional, realizadas com profissionais de nível superior (generalistas, e/ou fonoaudiólogo. As entrevistas serão realizadas com profissionais

- Grupos focais: 2 grupos com "os demais componentes das equipes nuclear e ampliada": 1 GF com agentes comunitários (cerca de 12 participantes); 1 GF com profissionais de nível técnico (cerca de 6 participantes)

- Total esperado: aproximadamente 28 profissionais da equipe multi-profissional da USF selecionada.

- Análise de conteúdo e temática.

- Critério de inclusão: aceite do convite para participar.

- Objetivos

\section{* Objetivo Geral}

Investigar o significado de comunidade para o trabalho em saúde a partir das demandas e necessidades médico-sociais em um serviço de atenção primária à saúde sob a lógica do Programa de Saúde da Familia (PSF) no município de São Paulo.

* Objetivos Específicos

Compreender como se processa (ou não) a incorporação de demandas e necessidades médicosociais da comunidade no trabalho da equipe multiprofissional do PSF a partir das temáticas: álcool e drogas, violência e saúde mental; identificar as possibilidades e os limites da atuação da equipe multiprofissional do PSF frente às demandas e necessidades médico-sociais, bem como as potencialidades da relação 'serviço-comunidade'.

Rua General Jardim, $36-2^{\circ}$ andar - Vila Buarque - Săo Paulo, SP - CEP 01223-010 Telefone: (11) 3218-4043 e-mail: smscep (2prefeitura sp.gov.br homepage: http://portal.prefeitura.sp.gov.br/secretarias/saude/organizacao/cepsm 
- O recrutamento dos entrevistados será feito dentro dos grupos profissionais indicados e o único critério de inclusão, alem da categoria profissional para cada uma das técnicas utilizadas, será o aceite do profissional convidado.

II - Considerações: É um estudo de caso que poderá ser pertinente para o conhecimento do sistema e de seus servidores (tanto do ponto de vista do conhecimento teórico como do conhecimento prático).

- Apresentação do Protocolo

> A Folha de Rosto está corretamente preenchida, e apresenta o termo de compromisso da pesquisadora. O projeto é claro e bem estruturado. Apresenta cronograma, modelo de entrevista e de roteiro de grupo focal, além de 2 modelos de TCLE (para cada uma das situações).

- O currículo do pesquisador responsável está de acordo com a proposta da pesquisa. É trabalho de Pós -Graduação (autora é terapeuta ocupacional) e sua orientadora mostra currículo compativel.

$>$ A proposta é de interesse para o conhecimento da área.

> A metodologia é adequada aos objetivos.

- Os direitos fundamentais do sujeito de pesquisa estão garantidos: informação, privacidade, recusa inócua, acesso ao pesquisador e CEP, etc).

- Termo de Consentimento Livre e Esclarecido (TCLE)

É conciso e objetivo, está redigido na forma de convite à participação no estudo. A linguagem é adequada ao nível sócio-cultural dos sujeitos de pesquisa e há descrição suficiente dos procedimentos. Há explicitação das garantias referidas no item IV. 1 da Res.CNS 196/96, permitindo uma decisão consciente do sujeito da pesquisa e sua saida se o desejar.

\section{Parecer do CEP: Projeto Aprovado}

Como procedimento adotado por este Comitê de Ética em Pesquisa, solicitamos a inclusão, no Termo de Consentimento Livre e Esclarecido do seguinte: qualquer questão, dúvida, esclarecimento ou reclamacăo sobre os aspectos éticos dessa pesquisa, favor entrar em contato com: Comitê de Ética em Pesquisas da Secretaria Municipal da Saúde de São Paulo - Rua General Jardim. $36-2^{\circ}$ andar - Telefone: 3218-4043 - e-mail: smscep@prefeitura.sp.gov.br.

Lembramos que este parecer não basta para que seu estudo possa se realizar dentro da unidade, é necessária também a permissão administrativa da autoridade sanitária.

Salientamos os seguintes aspectos a serem considerados pelo pesquisador:

- O sujeito da pesquisa tem a liberdade de recusar-se a participar ou de retirar seu consentimento em qualquer fase da pesquisa, sem penalização alguma ou sem prejuizo ao seu cuidado (Res. CNS 196/96 - item IV.1f) e deve receber uma cópia do Termo de Consentimento livre e esclarecido, na íntegra, por ele assinado (item IV.2.d)

- O pesquisador deve desenvolver a pesquisa conforme delineada no protocolo aprovado. Eventuais modificações ou emendas ao protocolo devem ser apresentadas ao CEP de forma clara e sucinta, identificando a parte do protocolo a ser modificada e suas justificativas. O relatório final deve ser apresentado ao CEP, logo que o estudo estiver concluido.

Atenciosamente,

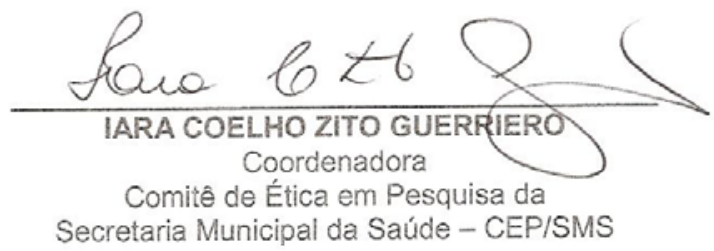

Rua General Jardim, $36-2^{\circ}$ andar - Vila Buarque - São Paulo, SP - CEP 01223-010 Telefone: (11) 3218-4043 e-mail: smscep@prefeitura.sp.gov.br homepage: http://portal.prefeitura.sp.gov.br/secretarias/saude/organizacao/cepsms 


\section{ANEXO B - TERMOS DE CONSENTIMENTO LIVRE E ESCLARECIDO}

\section{TERMO DE CONSENTIMENTO LIVRE E ESCLARECIDO PARA OS PARTICIPANTES DAS ENTREVISTAS}

Meu nome é Ariane Machado Palma. Sou terapeuta ocupacional e aluna do Programa de Pósgraduação em Medicina Preventiva da Faculdade de Medicina da Universidade de São Paulo - FMUSP. Estou desenvolvendo a pesquisa "O significado de comunidade para o trabalho em saúde: demandas e necessidades médico-sociais no cotidiano das práticas do Programa de Saúde da Família”. O objetivo é investigar o significado de comunidade para o trabalho em saúde e a incorporação de demandas e necessidades médico-sociais em um serviço de atenção primária à saúde sob a lógica do Programa de Saúde da Família. Para isto, necessito entrevistá-lo. Assim, solicito por meio deste documento o seu consentimento para participar deste estudo. Gostaria de esclarecer que sua participação é voluntária e que não será cobrado nada por ela, assim como não haverá remuneração financeira caso participe. Esclareço ainda que poderá pedir mais informações ${ }^{*}$ a respeito do estudo a qualquer momento e tem todo o direito de se recusar a participar, inclusive podendo abandoná-lo quando desejar, sem que isso lhe traga prejuízos de qualquer espécie. Não será necessária sua identificação. O anonimato e o sigilo dos seus dados e da Unidade na qual trabalha serão mantidos por ocasião da divulgação dos resultados da pesquisa em eventos e/ou periódicos. Caso aceite, receberá uma cópia assinada desse termo na íntegra. Você concorda em participar?

Desde já agradeço a sua colaboração,

Ariane Machado Palma
Terapeuta ocupacional - CREFITO-3/7861
Programa de Pós-Graduação em Medicina Preventiva, FM-
USP

Prof. Dra. Márcia Thereza Couto

Programa de Pós-Graduação em Medicina Preventiva, FM-

USP

$\mathrm{Eu}$, , declaro que estou de acordo em participar como entrevistado (a) da pesquisa "O significado de comunidade para o trabalho em saúde: demandas médico-sociais no cotidiano das práticas do Programa de Saúde da Família”. A minha participação é voluntária, sendo que posso recusar a participar a qualquer momento. Entendo que minha decisão não afetará de forma alguma na continuidade do meu trabalho, ou mesmo não haverá qualquer complicação judicial pelos meus depoimentos.

Assinatura do entrevistado (a)

\footnotetext{
* Quaisquer esclarecimentos, favor entrar em contato com: Ariane Machado Palma - Telefone: 9800-0006 e/ou Prof. Dra. Márcia Thereza Couto - Departamento de Medicina Preventiva - Faculdade de Medicina da USP FMUSP. Av. Dr. Arnaldo, 455 - $2^{\circ}$ andar - sala 2241 - Telefone: 3061-7091. Qualquer questão, dúvida, esclarecimento ou reclamação sobre os aspectos éticos dessa pesquisa, favor entrar em contato com: Comitê de Ética em Pesquisas da Secretaria Municipal da Saúde de São Paulo - Rua General Jardim, 36 - $2^{\circ}$ andar Telefone: 3218-4043 - e-mail: smscep@prefeitura.sp.gov.br
} 


\section{TERMO DE CONSENTIMENTO LIVRE E ESCLARECIDO PARA OS PARTICIPANTES DOS GRUPOS FOCAIS}

Meu nome é Ariane Machado Palma. Sou terapeuta ocupacional e aluna do Programa de Pósgraduação em Medicina Preventiva da Faculdade de Medicina da Universidade de São Paulo - FMUSP. Estou desenvolvendo a pesquisa "O significado de comunidade para o trabalho em saúde: demandas e necessidades médico-sociais no cotidiano das práticas do Programa de Saúde da Família”. O objetivo é investigar o significado de comunidade para o trabalho em saúde e a incorporação de demandas e necessidades médico-sociais em um serviço de atenção primária à saúde sob a lógica do Programa de Saúde da Família. Para isto, conto com sua participação neste Grupo Focal. Assim, solicito por meio deste documento o seu consentimento para participar deste estudo. Gostaria de esclarecer que sua participação é voluntária e que não será cobrado nada por ela, assim como não haverá remuneração financeira caso participe. Esclareço ainda que poderá pedir mais informações ${ }^{*}$ a respeito do estudo a qualquer momento e tem todo o direito de se recusar a participar, inclusive podendo abandoná-lo quando desejar, sem que isso lhe traga prejuízos de qualquer espécie. Não será necessária sua identificação. O anonimato e o sigilo dos seus dados e da Unidade na qual trabalha serão mantidos por ocasião da divulgação dos resultados da pesquisa em eventos e/ou periódicos. Caso aceite, receberá uma cópia assinada desse termo na íntegra. Você concorda em participar?

Desde já agradeço a sua colaboração,

Ariane Machado Palma
Terapeuta ocupacional - CREFITO-3/7861
Programa de Pós-Graduação em Medicina Preventiva, FM-

Prof. Dra. Márcia Thereza Couto Programa de Pós-Graduação em Medicina Preventiva, FMUSP

Eu, , declaro que estou de acordo em participar como entrevistado (a) da pesquisa "O significado de comunidade para o trabalho em saúde: demandas médico-sociais no cotidiano das práticas do Programa de Saúde da Família”. A minha participação é voluntária, sendo que posso recusar a participar a qualquer momento. Entendo que minha decisão não afetará de forma alguma na continuidade do meu trabalho, ou mesmo não haverá qualquer complicação judicial pelos meus depoimentos.

Assinatura do entrevistado (a)

\footnotetext{
* Quaisquer esclarecimentos, favor entrar em contato com: Ariane Machado Palma - Telefone: 9800-0006 e/ou Prof. Dra. Márcia Thereza Couto - Departamento de Medicina Preventiva - Faculdade de Medicina da USP FMUSP. Av. Dr. Arnaldo, 455 - $2^{\circ}$ andar - sala 2241 - Telefone: 3061-7091. Qualquer questão, dúvida, esclarecimento ou reclamação sobre os aspectos éticos dessa pesquisa, favor entrar em contato com: Comitê de Ética em Pesquisas da Secretaria Municipal da Saúde de São Paulo - Rua General Jardim, 36 - $2^{\circ}$ andar Telefone: 3218-4043 - e-mail: smscep@prefeitura.sp.gov.br
} 
ANEXO C - ROTEIROS DAS ENTREVISTAS E GRUPO FOCAL

\author{
ROTEIRO PARA ENTREVISTA COM PROFISSIONAIS DA ESF
}

O SIGNIFICADO DE COMUNIDADE PARA O TRABALHO EM SAÚDE:

DEMANDAS E NECESSIDADES MÉDICO-SOCIAIS NO COTIDIANO DAS PRÁTICAS DO PROGRAMA DE SAÚDE DA FAMÍLIA

Roteiro para Entrevista com Profissionais da ESF

Local da Entrevista

Data________ Entrevistador/a

Início Término Duração

$N^{o}$ da Entrevista Data da transcrição

Revisor/a Data

Observações do entrevistador/a:

\title{
IDENTIFICAÇÃO
}

Nome completo

Idade

Escolaridade

Formação

Tempo de formação_

Cargo no PSF

Tempo de trabalho na ESF

Contato telefônico

Contato e-mail 


\section{ASPECTOS DA TRAJETÓRIA INDIVIDUAL}

1. Fale um pouco sobre a sua trajetória profissional até chegar ao seu momento atual.

2. Fale um pouco sobre o serviço em que trabalha. Como você percebe a realidade do seu território de atuação (a área de abrangência, a comunidade)? Como você percebe a estrutura e o funcionamento da ESF?

3. Como é trabalhar no PSF? Como é o seu cotidiano na ESF? Quais atividades desempenha? Como você percebe o resultado das suas ações?

\section{ASPECTOS DO SERVIÇO}

4. Como você percebe o resultado do trabalho da ESF, como um todo? Você acha que o serviço tem atingido os seus objetivos? Se a resposta for sim, comente. Se não, o que poderia melhorar?

5. Você acha que há comunicação entre o serviço e os usuários, e vice-versa? Como você entende a relação serviço x comunidade? Há coincidência entre o que o serviço propõe e o que os usuários esperam? Quais? Se não, explique o porquê.

6. Que demandas, necessidades e/ou solicitações mais aparecem via comunidade? No geral, como elas são encaminhadas? Como o serviço as acolhe?

7. Você se depara com demandas e necessidades relacionadas à violência? De que forma? Quanto? Poderia relatar ao menos um caso/situação que mais lhe chamou atenção.

8. Você se depara com demandas e necessidades relacionadas ao álcool e drogas? De que forma? Quanto? Poderia relatar ao menos um caso/situação que mais lhe chamou atenção.

9. Você se depara com demandas e necessidades relacionadas à saúde mental? De que forma? Quanto? Poderia relatar ao menos um caso/situação que mais lhe chamou atenção. 
10. No aspecto geral, como são abordados estes casos/situações no cotidiano do seu trabalho? E como a ESF os aborda?

11. Você encontra dificuldades para realizar o trabalho diante destes casos/situações? De que tipo? Há facilidades? De que tipo?

12. Em sua opinião, qual o papel da Saúde diante das demandas e necessidades relacionadas à violência, ao álcool e drogas, à saúde mental e até mesmo outras que vêem da comunidade?

\section{PERCEPÇÃO DO FENÔMENO}

13. Do seu ponto de vista, como você entende a violência? Como ela ocorre? Em que situações? Quais são suas causas (o porquê)? A violência é aceitável? Se sim, em que situações? Se não, comente. E na comunidade a violência é aceitável? Comente.

14. Como você entende o uso abusivo de álcool e drogas? Do seu ponto de vista, como ele ocorre? Em que situações? Quais são suas causas? O uso abusivo de álcool e drogas é aceitável? Se sim, em que situações? Se não, comente. E na comunidade uso abusivo de álcool e drogas é aceitável? Comente.

15. E quanto à saúde mental. Do seu ponto de vista, como você entende o sofrimento mental? Como ele ocorre? Em que situações? Quais são suas causas? O sofrimento mental é aceitável? Se sim, em que situações? Se não, comente. E na comunidade sofrimento mental é aceitável? Comente.

16. Como você se sente trabalhando diretamente com casos e/ou situações semelhantes a estas?

17. Você gostaria de comentar mais alguma coisa? Quer colocar sua opinião sobre esta entrevista? 
ROTEIRO PARA GRUPO FOCAL COM AGENTES COMUNITÁRIOS DE

SAÚDE DA ESF

O SIGNIFICADO DE COMUNIDADE PARA O TRABALHO EM SAÚDE:

DEMANDAS E NECESSIDADES MÉDICO-SOCIAIS NO COTIDIANO DAS PRÁTICAS DO

PRograma de SAÚdE da FAMÍlia

Roteiro para Grupo Focal com Agentes Comunitários de Saúde da ESF

Local do Grupo Focal

Data

/

Moderador

Relator

Início Término Duração

Gravação $n^{o}$ : Duração

Observações do Moderador/a:

IDENTIFICAÇÃO DOS PARTICIPANTES

\begin{tabular}{|l|l|l|c|c|}
\hline Nome completo & Idade & Escolaridade & $\begin{array}{c}\text { Tempo de } \\
\text { trabalho na } \\
\text { ESF }\end{array}$ & $\begin{array}{c}\text { Antes do PSF, já } \\
\text { trabalhou no setor } \\
\text { Saúde? }\end{array}$ \\
\hline & & & & \\
\hline & & & & \\
\hline & & & & \\
\hline & & & & \\
\hline
\end{tabular}

* Todos moram na comunidade que atuam? 


\section{APRESENTAÇÃO DO GRUPO}

Apresentação inicial.

Explicação a respeito do objetivo da pesquisa - conhecer o significado de comunidade para o trabalho em saúde por meio de discussão com o grupo (utiliza-se 03 temas para apreender as relações serviço x comunidade). Etapas: entrevistas e grupos de discussão, para aprofundamento das questões, escuta de opiniões e de sugestões. Devolutiva em janeiro/2009.

Leitura TCLE: * garantia da confidencialidade e respeito; * não há certo nem errado, gostaríamos de conhecer opiniões e o pensamento dos participantes; * o que for dito durante o grupo será transcrito, porém seu nome não será divulgado em nenhum momento. Dúvidas. Uso do gravador e registro. Tempo: 2 horas

Aquecimento - Caracterização dos participantes.

\section{Bloco 1 - ASPECTOS DO SERVIÇO}

01. No cotidiano de trabalho, vocês se deparam com demandas relacionadas à violência, álcool-drogas e saúde mental? Na experiência de vocês, como e quanto?

02. Vocês podem relatar casos/situações (de cada tipo) que mais lhe chamam a atenção guardando o anonimato da família e/ou do usuário? Como esses casos/situações chegam até vocês? Qual é a freqüência? Como acolhem, recebem e o que fazem diante desses casos/situações?

03. Casos/situações relacionados à violência, álcool-drogas e saúde mental fazem parte do trabalho da ESF? Como e em que medida?

04. Diante dos casos/situações, como vocês percebem o resultado das ações da equipe como um todo? Vocês acham que resolve? Que parte resolve e o que não resolve? O serviço tem atingido seus objetivos? O que vem dando certo e o que poderia melhorar na atuação individual e no serviço em geral? 
05. O que o serviço oferece é o que os usuários esperam? Como vocês entendem a relação do serviço com a comunidade? E a comunidade com o serviço? (Há problemas de comunicação?) Como é ser ACS da comunidade e do serviço ao mesmo tempo?

\section{Bloco 2 - PERCEPÇÃO DO FENÔMENO}

06. Como vocês entendem a violência? Como ela ocorre? Em que situações? Quais são suas causas (o porquê)? A violência é aceitável? Se sim, em que situações? Se não, comente.

07. Como vocês entendem o uso abusivo de álcool e drogas? Como ele ocorre? Em que situações? Quais são suas causas? O uso abusivo de álcool e drogas é aceitável? Se sim, em que situações? Se não, comente.

08. E quanto à saúde mental. Como vocês entendem o sofrimento mental? Como ele ocorre? Em que situações? Quais são suas causas? O sofrimento mental é aceitável? Se sim, em que situações? Se não, comente.

09. Finalizando: Como vocês se sentem trabalhando diretamente com questões como estas (temas: violência, uso abusivo de álcool e drogas e saúde mental)?

10. Gostariam de registrar algo mais? Alguma opinião sobre o Grupo que fizemos? Agradecimentos pela participação. 


\section{ANEXO D - LISTAGEM DAS ENTREVISTAS E GRUPO FOCAL}

ENTREVISTAS (função/cargo desempenhado, nome ${ }^{28}$ do participante, data da realização da entrevista e número de páginas da entrevista transcrita):

01. Médico ESF A - Amanda - 08/04/2008 - 21p.

02. Enfermeiro ESF A - Simone - 08/04/2008 - 32p.

03. Médico ESF B - Marta - 15/04/2008 - 21p.

04. Enfermeiro ESF B - Roberta - 10/04/2008 - 19p.

05. Cirurgião-Dentista ESF A - César - 09/04/2008 - 20p.

06. Cirurgiã-Dentista ESF B - Telma - 15/04/2008 - 14p.

07. Psicóloga ESF A e B - Rebeca - 26/04/2008 - 26p.

08. Psiquiatra ESF A e B - Romeu - 24/04/2008 - 21p.

09. Fonoaudióloga ESF A e B - Aline - 05/05/2008 - 15p.

10. Fisioterapeuta ESF A e B - Letícia - 09/04/2008 - 24p.

11. Terapeuta Ocupacional ESF A e B - Luana- 18/04/2008 - 16p.

12. Auxiliar Cirurgião Dentista ESF A e B - Célia - 12/05/2008 - 13p.

13. Auxiliar de Enfermagem ESF A - Camila- 14/05/2008 - 13p.

14. Auxiliar de Enfermagem ESF B - Raquel - 16/05/2008 - 19p.

15. Auxiliar de Enfermagem ESF B - Andréa - 16/05/2008 - 11p.

\footnotetext{
${ }^{28}$ Nomes fictícios para preservar sigilo.
} 
GRUPO FOCAL (função/cargo desempenhado e nome ${ }^{29}$ do participante):

Grupo focal (parte A) - 24/04/2008

01. ACS - Marcela

02. ACS - Teresa

03. ACS - Rute

04. ACS - Marisa

05. ACS - Manuela

06. ACS - Gabriela

07. ACS - Isabele

08. ACS - Cláudia

09. ACS - Michele

10. ACS - Corina

Grupo focal (parte B) - 09/05/2008

01. ACS - Marcela

02. ACS - Teresa

03. ACS - Marisa

04. ACS - Gabriela

05. ACS - Isabele

06. ACS - Michele

07. ACS - Paula

\footnotetext{
${ }^{29}$ Nomes fictícios para preservar o sigilo.
} 